CONTROLE BIOLÓGICO DE Hypsipyla grandella Zeller (LEPIDOPTERA: PYRALIDAE) E NOVOS RELATOS DE ÁCAROS E FUNGOS EM MOGNO (Swietenia macrophylla King) EM BRASÍLIA/DF

MARCELO TAVARES DE CASTRO

TESE DE DOUTORADO EM AGRONOMIA

BRASÍLIA/DF

MARÇO/2016 
CONTROLE BIOLÓGICO DE Hypsipyla grandella Zeller (LEPIDOPTERA: PYRALIDAE) E NOVOS RELATOS DE ÁCAROS E FUNGOS EM MOGNO (Swietenia macrophylla King) EM BRASÍLIA/DF

MARCELO TAVARES DE CASTRO

ORIENTADORA: ROSE GOMES MONNERAT

TESE DE DOUTORADO EM AGRONOMIA

PUBLICAÇÃO: 039D/2016

BRASÍLIA/DF

MARÇO/2016 
UNIVERSIDADE DE BRASÍLIA

FACULDADE DE AGRONOMIA E MEDICINA VETERINÁRIA

PROGRAMA DE PÓS-GRADUAÇÃO EM AGRONOMIA

\title{
CONTROLE BIOLÓGICO DE Hypsipyla grandella Zeller (LEPIDOPTERA: PYRALIDAE) E NOVOS RELATOS DE ÁCAROS E FUNGOS EM MOGNO (Swietenia macrophylla King) EM BRASÍLIA/DF
}

\author{
MARCELO TAVARES DE CASTRO
}

TESE DE DOUTORADO SUBMETIDA À FACULDADE DE AGRONOMIA E MEDICINA VETERINÁRIA DA UNIVERSIDADE DE BRASÍLIA, COMO PARTE DOS REQUISITOS NECESSÁRIOS À OBTENÇÃO DO GRAU DE DOUTOR EM AGRONOMIA.

APROVADA POR:

Rose Gomes Monnerat, Dra. Pesquisadora da Embrapa Recursos Genéticos e Biotecnologia (Orientadora), CPF: 512.803.701-06, E-mail: rose.monnerat@embrapa.br

Marina Regina Frizzas, Dra. Professora Adjunta do Dep. de Zoologia - Universidade de Brasília (UnB), CPF: 249.222.768-58, E-mail: frizzas@unb.br

Mauro Eloi Nappo, Dr. Professor Adjunto do Dep. de Eng. Florestal - Universidade de Brasília (UnB), CPF: 651.200.516-34, E-mail: mauronappo@yahoo.com.br

Edison Ryoiti Sujii, Dr. Pesquisador da Embrapa Recursos Genéticos e Biotecnologia, CPF: 153.599.481-91, E-mail: edison.sujii@embrapa.br

Carlos Marcelo Silveira Soares, Dr. Pesquisador do Instituto Mato-grossense do Algodão (IMA-MT), CPF: 490.618.600-91, E-mail: carlos.marcelo.soares@gmail.com 


\section{FICHA CATALOGRÁFICA}

\section{Castro, Marcelo Tavares de}

CONTROLE BIOLÓGICO DE Hypsipyla grandella Zeller (LEPIDOPTERA: PYRALIDAE) E NOVOS RELATOS DE ÁCAROS E FUNGOS EM MOGNO (Swietenia macrophylla King) EM BRASÍLIA/DF.

Orientação: Rose Gomes Monnerat - Brasília, DF, 2016. 177 p.: il.

Tese de Doutorado (D)- Universidade de Brasília/Faculdade de Agronomia e Medicina Veterinária. 2016.

1. Broca-do-mogno. 2. Biocontrole. 3. Bacillus thuringiensis. 4. Beauveria bassiana. 5. Ácaros plantícolas. 6. Fungos fitopatogênicos. I. Castro, M. T. II. Título.

\section{REFERÊNCIA BIBLIOGRÁFICA}

CASTRO, M. T. Controle biológico de Hypsipyla grandella Zeller (Lepidoptera: Pyralidae) e novos relatos de ácaros e fungos em mogno (Swietenia macrophylla King) em Brasília/DF. Brasília: Faculdade de Agronomia e Medicina Veterinária, Universidade de Brasília, 2016, 177 p.: il. Tese de Doutorado.

\section{CESSÃO DE DIREITOS}

NOME DO AUTOR: Marcelo Tavares de Castro

TÍTULO DA TESE: Controle biológico de Hypsipyla grandella Zeller (Lepidoptera: Pyralidae) e novos relatos de ácaros e fungos em mogno (Swietenia macrophylla King) em Brasília/DF.

GRAU: Doutor

ANO: 2016

É concedida à Universidade de Brasília permissão para reproduzir cópias desta tese de doutorado para única e exclusivamente propósitos acadêmicos e científicos. $\mathrm{O}$ autor reserva para si os outros direitos autorais de publicação. Nenhuma parte dessa tese de doutorado pode ser reproduzida sem a autorização por escrito do autor. Citações são estimuladas, desde que citada a fonte.

Marcelo Tavares de Castro

CPF: 013.715.891-27

Email: marceloengflorestal@gmail.com 
"Se um dia tiver que escolher entre o mundo e o amor... lembre-se: se escolher o mundo ficará sem o amor, mas se escolher o amor, com ele você conquistará o mundo."

Albert Einstein 


\section{AGRADECIMENTOS}

Agradeço a Deus, fonte criadora e inspiradora, pela vida e pelas inúmeras conquistas de ontem, hoje e sempre.

Aos meus pais, Berilo e Marli, meu alicerce. Toda a minha gratidão e amor, sempre. Aos meus irmãos, Katiane e Márcio, meus melhores amigos. Amo-os. Ao meu cunhado, Humberto, e à minha afilhada, Bibi, na qual não consigo mais viver sem.

À Rose Monnerat, minha querida orientadora, pelos auxílios, compreensão, puxões de orelha, amizade e carinho. Você é um exemplo de pessoa e profissional a ser seguido.

Um agradecimento especial para a Floresta, meu refúgio, meu local de trabalho, lazer, descanso e alegrias. À Engenharia Florestal, mais que um curso de graduação, uma filosofia de vida. Aos meus amigos da Florestal, inúmeros, na qual não convém citar, mas sim agradecer pelos agradáveis momentos. Viva a floresta!

Ao mogno, Swietenia macrophylla King, minha espécie favorita, árvore magnífica, fonte de vida e pesquisas.

À Hypsipyla grandella, que surgiu espontaneamente, como uma mágica, para que eu realizasse os estudos. E que também me permitiu criá-las e realizar os ensaios de mortalidade com os agentes de biocontrole.

À Embrapa Recursos Genéticos e Biotecnologia, pelo apoio físico e funcional, e pela oportunidade de realização do doutorado.

À Universidade de Brasília, na qual estou desde a graduação, pelos inúmeros ensinamentos. Agradeço aos professores da Faculdade de Agronomia, especialmente aos professores Blum, Nara e Cristina, pelos grandes ensinamentos. 
Tenho muito a agradecer à Dra. Denise Návia e ao Dr. Carlos Flechtmann, pelo auxílio na identificação e descrição dos ácaros que encontramos associados ao mogno. Agradeço também à Mércia, pela ajuda com os desenhos. Muito obrigado!

À Ana, pelo auxílio na Microscopia Eletrônica de Varredura e pelos momentos de risada (de desespero). As fotos ficaram muito boas!

Ao meu amigo-irmão Sandro Montalvão, mais de cinco anos de amizade, sempre com a certeza de que podemos contar um com o outro. Agradeço muito, por tudo!

À amiga Flávia, foram tantas conversas, sempre muito construtivas, sobre tudo! Grande parte dos avanços na tese foi por conta desses nossos bate-papos. Conte comigo!

Aos amigos Robson e Fabiane, mais de 10 anos hilários de amizade e risadas constantes.

Aos colegas e amigos que fiz no LBE, Antônio, Anabele, Briana, Carla, Clara, Cris, Luiza, Elias, Lunalva, Evelin, Mayco, Jório, Marcel, Marcelo, Marina, Marcella, Neila, Zonaite, Fernanda, Lílian, Érica e Paulo. Obrigado pelos inúmeros momentos de descontração e também de aprendizado!

À amiga Rafaela Borges, por ter ido comigo ao Congresso Mundial Florestal (foi top!) e também pelas inúmeras conversas e debates sobre os variados temas florestais.

Ao professor Mauro do Departamento de Eng. Florestal da UnB, pelas colocações pontuais e pertinentes durante o trabalho e também no exame de qualificação do doutorado.

À Daniela Aguiar, pelo auxílio na identificação molecular da Beauveria e também na confecção do artigo científico.

Ao Dr. Marcelo Soares, pelas inúmeras sugestões de pesquisa e pelas também inúmeras descontrações no LBE, fazendo o dia ficar mais agradável.

À Dra. Bárbara Eckstein, pela ajuda na parte fitopatológica da tese. Sempre bom trabalhar com você! Desejo muito sucesso em sua jornada na pesquisa! 
Ao Dr. Marcílio Thomazini, da Embrapa Florestas, e ao Dr. Alexandre Lunz, da Embrapa Amazônia, pela ajuda inicial no desenvolvimento desse trabalho. Muito obrigado!

Aos funcionários da Embrapa Recursos Genéticos e Biotecnologia.

Aos membros da banca, Dra. Marina Frizzas, Dr. Mauro Nappo, Dr. Edison Sujii e Dr. Carlos Marcelo, pelas opiniões e sugestões sobre o trabalho, sempre muito construtivas.

A todos aqueles que, direta ou indiretamente, auxiliaram no bom andamento e na conclusão dessa tese.

MUITO OBRIGADO! 


\section{ÍNDICE GERAL}

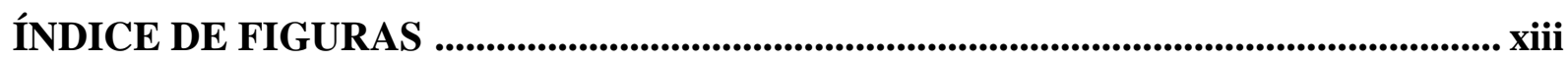

ÍNDICE DE TABELAS .................................................................................................. xvi

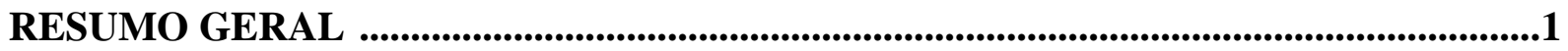

GENERAL ABSTRACT ....................................................................................................3

INTRODUÇÃO GERAL .......................................................................................................5

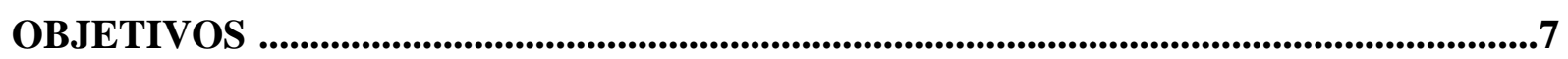

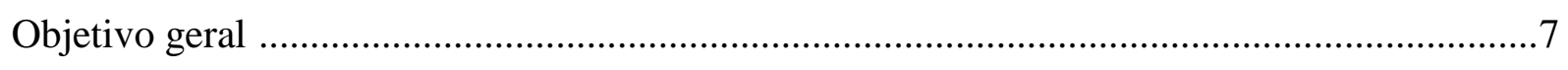

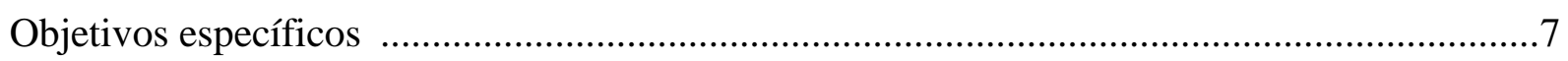

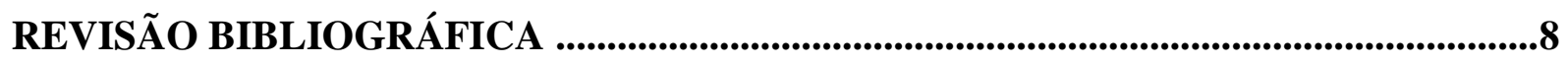

REFERÊNCIAS BIBLIOGRÁFICAS _......................................................................22

CAPÍTULO 1 - DANOS EM FRUTOS DE MOGNO (Swietenia macrophylla King) CAUSADOS POR Hypsipyla grandella Zeller (Lepidoptera: Pyralidae) EM BRASÍLIA, DISTRITO FEDERAL .....................................................................................................................41

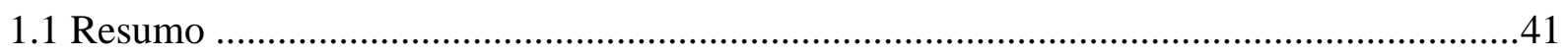

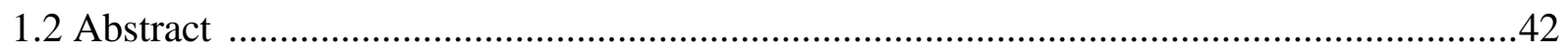

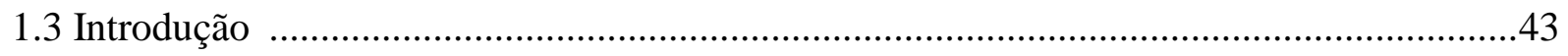

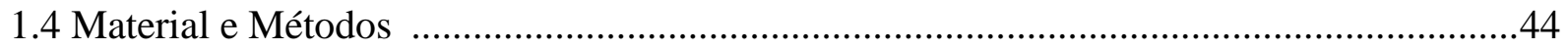

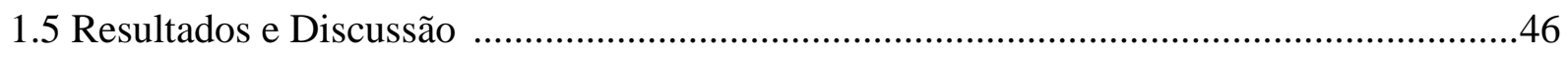

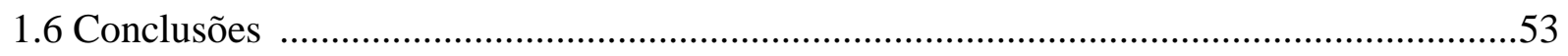

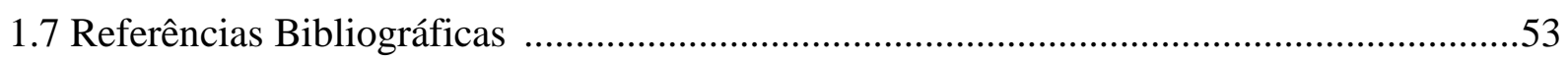

CAPÍTULO 2 - ESTABELECIMENTO DE CRIAÇÃO E BIOLOGIA DE Hypsipyla grandella Zeller (Lepidoptera: Pyralidae) ALIMENTADAS COM SEMENTES DE MOGNO (Swietenia macrophylla King) .................................................................................57

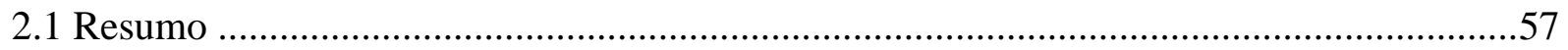

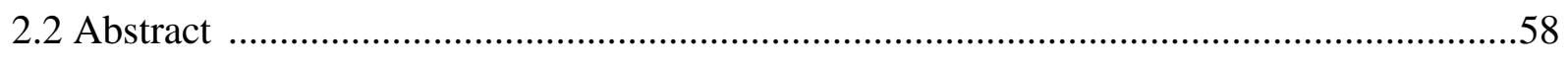

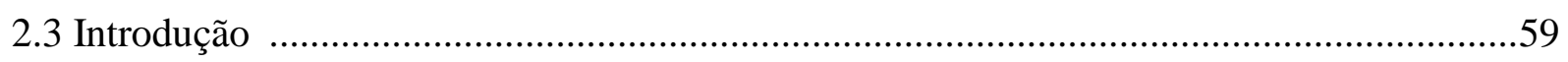

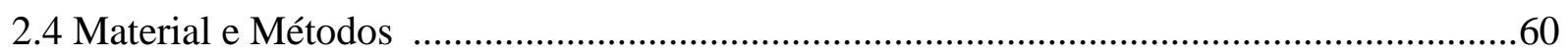

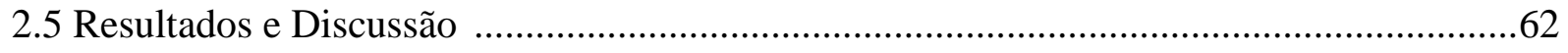

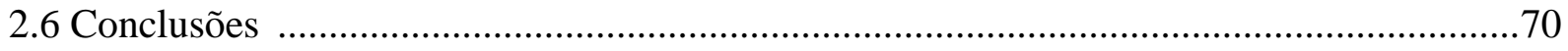


CAPÍtULO 3 - OCORRÊNCIA NATURAL E PATOGENICIDADE DE UM ISOLADO DE Beauveria bassiana (Bálsamo) Vuill. Á Hypsipyla grandella Zeller (Lepidoptera: Pyralidae) COLETADO EM BRASÍLIA, DISTRITO FEDERAL ..........77

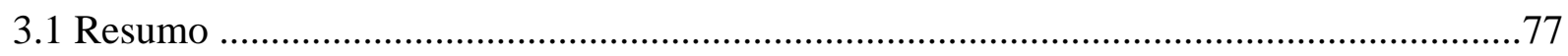

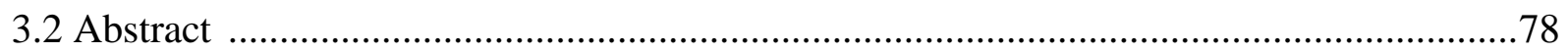

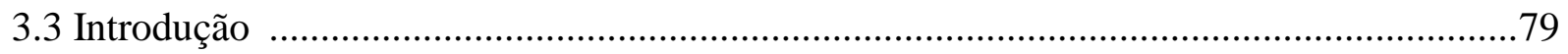

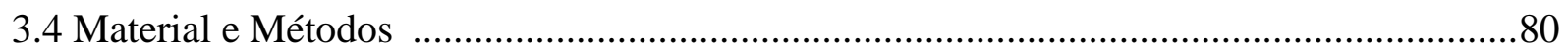

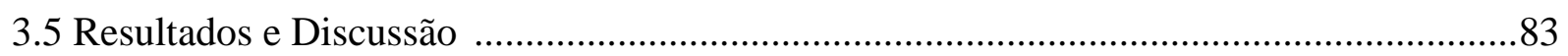

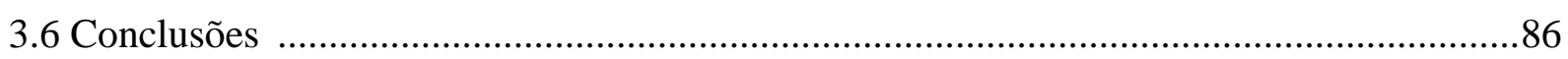

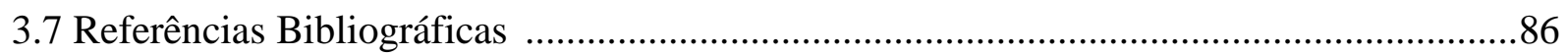

CAPÍtUlO 4 - CONTROLE BIOLÓGICO DE Hypsipyla grandella Zeller (Lepidoptera: Pyralidae) COM Bacillus thuringiensis Berliner EM LABORATÓRIO .90

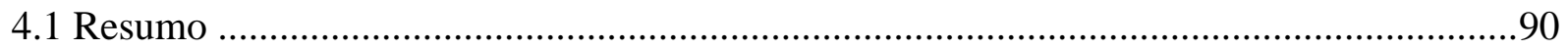

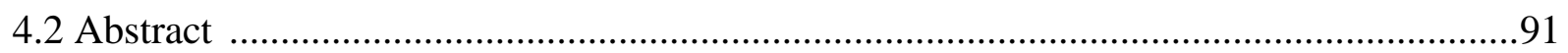

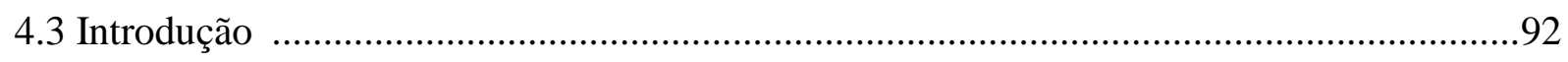

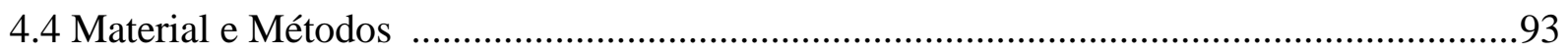

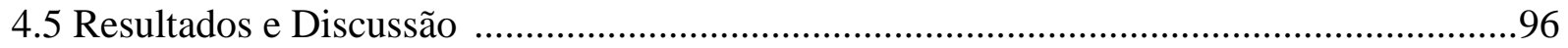

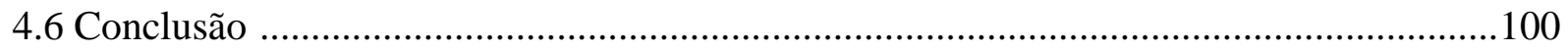

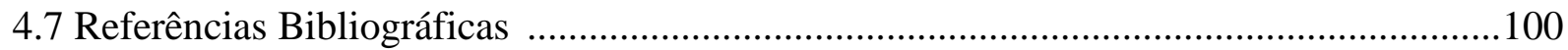

CAPÍTULO 5 - CONTROLE BIOLÓGICO DE Hypsipyla grandella Zeller (Lepidoptera: Pyralidae) COM O USO SISTÊMICO DE Bacillus thuringiensis Berliner EM MUDAS DE Swietenia macrophylla King ............................................................106

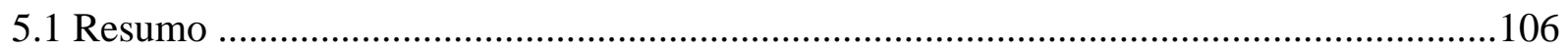

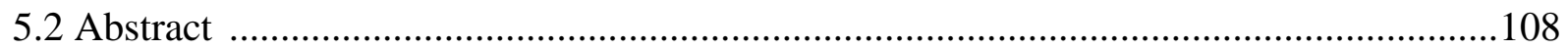

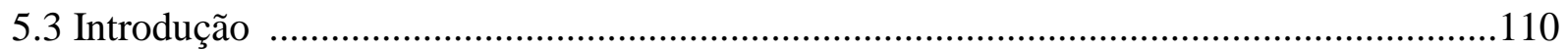

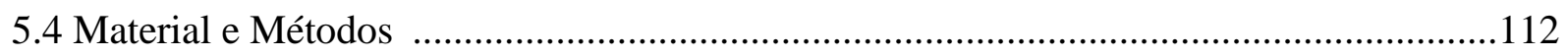

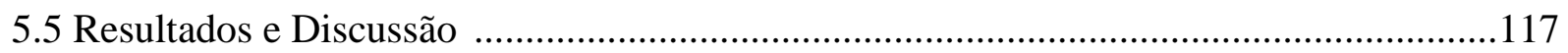

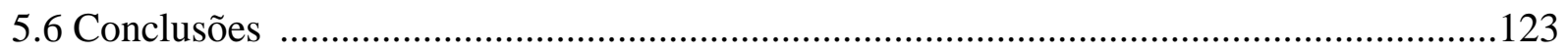

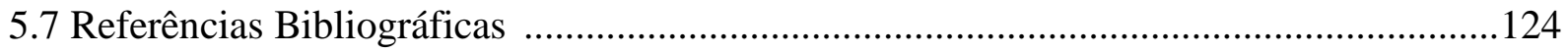


CAPÍTULO 6 - ÁCAROS ASSOCIADOS AO MOGNO (Swietenia macrophylla King) NO BRASIL - NOVOS RELATOS E IDENTIFICAÇÃO DE UMA NOVA ESPÉCIE DA FAMÍLIA ERIOPHYIDAE ............................................................................................131

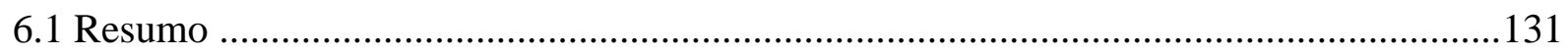

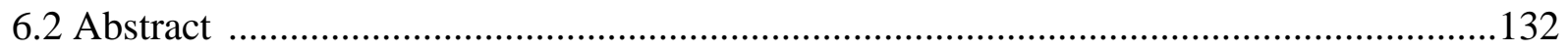

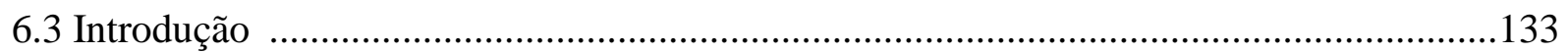

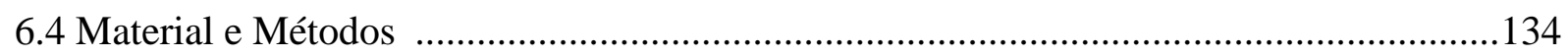

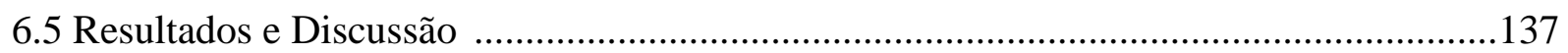

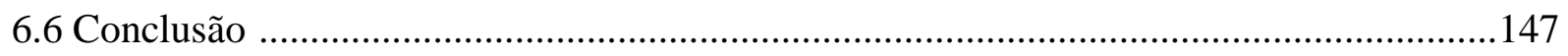

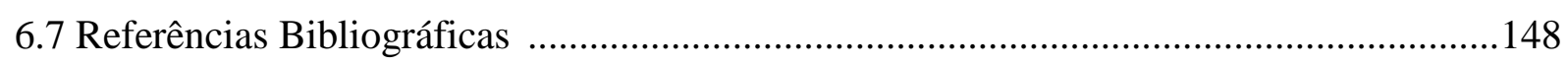

CAPÍTULO 7 - ANÁLISE DA OCORRÊNCIA DE FUNGOS EM SEMENTES DE MOGNO (Swietenia macrophylla King) COLETADAS EM BRASÍLIA, DISTRITO

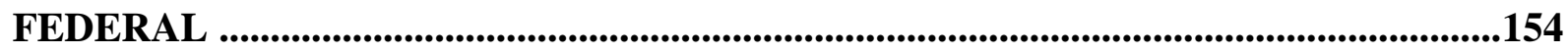

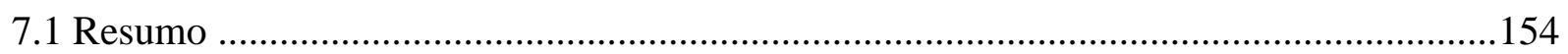

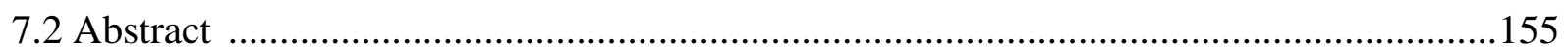

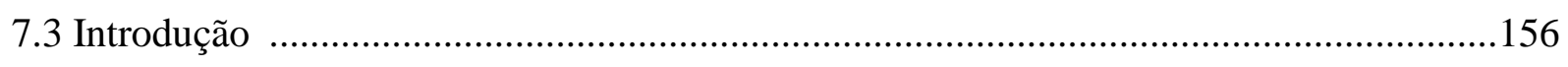

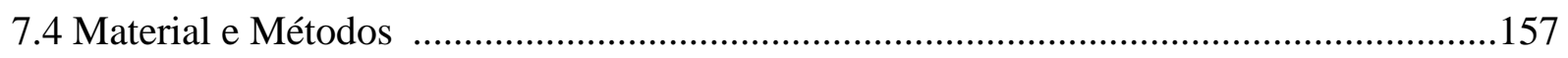

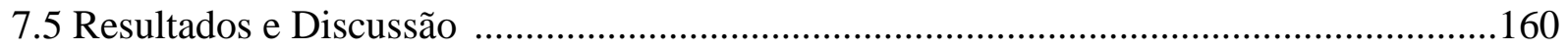

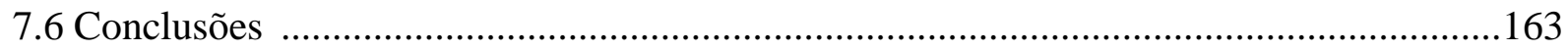

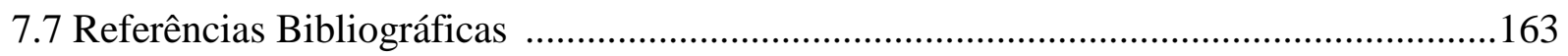

CAPÍTULO 8 - NOVOS RELATOS DE FUNGOS FOLIARES EM MOGNO (Swietenia macrophylla King) NO BRASIL ............................................................................166

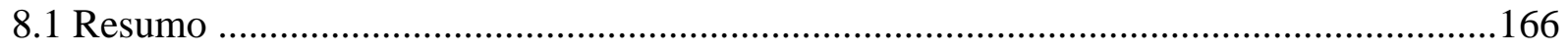

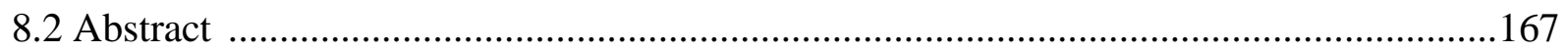

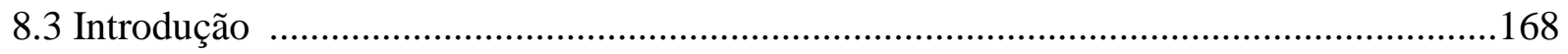

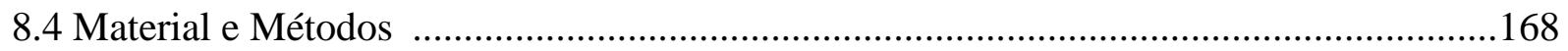

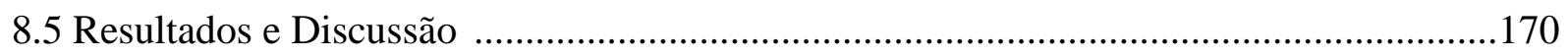

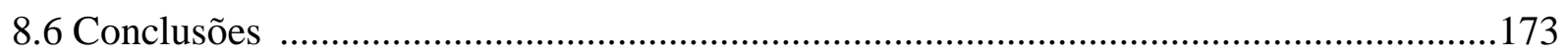

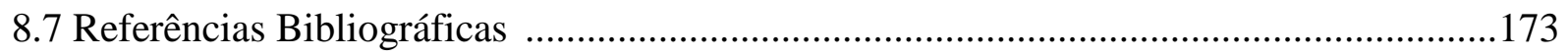




\section{ÍNDICE DE FIGURAS}

\section{REVISÃO BIBLIOGRÁFICA}

Figura 1. Zona de ocorrência de Swietenia macrophylla na América do Sul, abrangendo seis países: Venezuela, Colômbia, Equador, Peru, Bolívia e Brasil.

CAPÍTULO 1 - DANOS EM FRUTOS DE MOGNO (Swietenia macrophylla King) CAUSADOS POR Hypsipyla grandella Zeller (Lepidoptera: Pyralidae) EM BRASÍLIA, DISTRITO FEDERAL

Figura 1. Número de orifícios feitos pela Hypsipyla grandella em frutos de mogno. .46

Figura 2 (A - F). Predação em frutos de mogno pela Hypsipyla grandella.

Figura 3. Número de lagartas de Hypsipyla grandella por fruto de mogno. . .48

Figura 4. Pupas (setas) de Hypsipyla grandella no interior do fruto de mogno. .49

Figura 5. Número de pupas de Hypsipyla grandello por fruto de mogno. .51

CAPÍTULO 2 - ESTABELECIMENTO DE CRIAÇÃO E BIOLOGIA DE Hypsipyla grandella Zeller (Lepidoptera: Pyralidae) ALIMENTADAS COM SEMENTES DE MOGNO (Swietenia macrophylla King)

Figura 1 (A - E). Criação de Hypsipyla grandella.

Figura 2. Número de ovos por sucessivas gerações de Hypsipyla grandella. .64

Figura 3. Postura individual e em grupo de Hypsipyla grandella em tecido tipo "morim" e detalhes do formato do ovo visto em microscopia estereoscópica. .66

Figura 4. Número de adultos machos e fêmeas de Hypsipyla grandella, durante oito gerações sucessivas.

Figura 5. Número de adultos de Hypsipyla grandella deformados quando alimentados com sementes de mogno, durante sucessivas gerações, até a F8.

CAPÍtULO 3 - OCORRÊNCIA NATURAL E PATOGENICIDADE DE UM ISOLADO DE Beauveria bassiana (Bálsamo) Vuill. Á Hypsipyla grandella Zeller (Lepidoptera: Pyralidae) COLETADO EM BRASÍLIA, DISTRITO FEDERAL

Figura 1 (A - F). Beauveria bassiana isolada de Hypsipyla grandella. .84 
Figura 2. Árvore filogenética dos isolados do gênero Beauveria através da análise Bayesiana da região intergênica Bloc. Os valores de suporte da inferênica Bayesiana são mostrados na árvore.

\section{CAPÍtULO 5 - CONTROLE BIOLÓGICO DE Hypsipyla grandella Zeller} (Lepidoptera: Pyralidae) COM O USO SISTÊMICO DE Bacillus thuringiensis Berliner EM MUDAS DE Swietenia macrophylla King

Figura 1. Mudas de mogno produzidas em casa de vegetação de janeiro de 2014 a maio de 2015

Figura 2. Ovo de Hypsipyla grandella em tecido fixado na planta com o auxílio de fita crepe.

Figura 3. Inoculação da solução de Bacillus thuringiensis em mudas de mogno via solo. ..115

Figura 4 (A - C). Ataque de Hypsipyla grandella em mudas de mogno. 118

Figura 5 (A e B). Destruição da gema apical em muda de mogno pela Hypsipyla grandella.

Figura 6. Lagarta de Hypsipyla grandella morta próxima ao broto terminal em planta de mogno inoculada com a bactéria Bacillus thuringiensis.

Figura 7. Número de plantas que apresentaram teia, goma, excrementos e folhas secas de acordo com o uso de diferentes tratamentos quanto ao ataque de Hypsipyla grandella.

CAPÍTULO 6 - ÁCAROS ASSOCIADOS AO MOGNO (Swietenia macrophylla King) NO BRASIL - NOVOS RELATOS E IDENTIFICAÇÃO DE UMA NOVA ESPÉCIE DA FAMÍLIA ERIOPHYIDAE

Figura 1 (A - D). Infestação de uma espécie nova de Aceria em mogno. ............................138

Figura 2. Espécie nova de Aceria em mogno. ................................................................143

Figura 3 (A - C). Microscopia de Aceria sp. n. encontrada em mogno. .............................144

Figura 4 (A e B). Sintomas de Eutetranychus banksi em folhas de mogno. .........................145

Figura 5 (A e B). Adultos de Eutetranychus banksi em folhas de mogno. ...........................146

\section{CAPÍTULO 7 - ANÁLISE DA OCORRÊNCIA DE FUNGOS EM SEMENTES DE MOGNO (Swietenia macrophylla King) COLETADAS EM BRASÍLIA, DISTRITO FEDERAL}

Figura 1 (A - G). Alguns fungos encontrados em sementes de mogno pelo Blotter-test. ...161 
CAPÍTULO 8 - NOVOS RELATOS DE FUNGOS FOLIARES EM MOGNO (Swietenia macrophylla King) NO BRASIL

Figura 1 (A - F). Fungos foliares associados ao mogno. 


\section{INDICE DE TABELAS}

\section{REVISÃO BIBLIOGRÁFICA}

Tabela 1. Insetos associados ao mogno no mundo, com excessão da Hypsipylla spp.

Tabela 2. Microrganismos tóxicos a Hypsipyla robusta e Hypsipyla grandella.

CAPÍTULO 1 - DANOS EM FRUTOS DE MOGNO (Swietenia macrophylla King) CAUSADOS POR Hypsipyla grandella Zeller (Lepidoptera: Pyralidae) EM BRASÍLIA, DISTRITO FEDERAL

Tabela 1. Locais de coleta de frutos de mogno em Brasília/DF. .44

Tabela 2. Matriz de correlação entre as variáveis analisadas. 52

Tabela 3. Matriz de correlação entre o número de lagartas e pupas de Hypsipyla grandella e o número de sementes de mogno danificadas. .52

CAPÍTULO 2 - ESTABELECIMENTO DE CRIAÇÃO E BIOLOGIA DE Hypsipyla grandella Zeller (Lepidoptera: Pyralidae) ALIMENTADAS COM SEMENTES DE MOGNO (Swietenia macrophylla King)

Tabela 1. Peso e tamanho do último instar de Hypsipyla grandella quando mantidas em diferentes dietas.

Tabela 2. Média do comprimento e peso de lagartas de último instar de Hypsipyla grandella mantidas em dieta à base de sementes de mogno, após oito gerações sucessivas.

Tabela 3. Peso e tamanho de pupas de Hypsipyla grandella mantidas em dieta natural à base de sementes de mogno em sucessivas gerações. .68

\section{CAPÍtULO 4 - CONTROLE BIOLÓGICO DE Hypsipyla grandella Zeller} (Lepidoptera: Pyralidae) COM Bacillus thuringiensis Berliner EM LABORATÓRIO

Tabela 1. Estirpes de Bacillus thuringiensis utilizadas nos bioensaios seletivos. . .93

Tabela 2. Mortalidade de lagartas de Hypsipyla grandella por estirpes de Bacillus thuringiensis.

Tabela 3. Concentração letal $\left(\mathrm{CL}_{50}\right)$ das estirpes de Bacillus thuringiensis para matar lagartas de Hypsipyla grandella da população testada após cinco dias de tratamento (96 horas).

Tabela 4. Concentração letal $\left(\mathrm{CL}_{50}\right)$ das toxinas puras para matar lagartas de Hypsipyla grandella da população testada após cinco dias de tratamento (96 horas). . .98 
CAPÍtULO 5 - CONTROLE BIOLÓGICO DE Hypsipyla grandella Zeller (Lepidoptera: Pyralidae) COM O USO SISTÊMICO DE Bacillus thuringiensis Berliner EM MUDAS DE Swietenia macrophylla King

Tabela 1. Eficiência dos tratamentos bacterianos quanto à mortalidade de Hypsipyla grandella e tamanho médio da galeria formada pelo inseto em mudas de mogno inoculadas com $B t$ via solo. 120

CAPÍTULO 7 - ANÁLISE DA OCORRÊNCIA DE FUNGOS EM SEMENTES DE MOGNO (Swietenia macrophylla King) COLETADAS EM BRASÍLIA, DISTRITO FEDERAL

Tabela 1. Fungos encontrados em sementes de mogno a partir do Blotter-test. 160

Tabela 2. Fungos encontrados em sementes de mogno pelo método do sintoma em plântulas. 


\section{RESUMO GERAL}

O mogno (Swietenia macrophylla King) é uma espécie florestal extremamente apreciada pela qualidade de sua madeira, plasticidade silvicultural e beleza ornamental. O seu corte em áreas naturais foi tão abusivo que atualmente é uma espécie protegida e ameaçada de extinção. Apesar disso, o cultivo do mogno tem se estabelecido em diversas partes do mundo, inclusive no Brasil, tanto em plantios comerciais, quanto na arborização de diversas cidades. Porém, um dos principais entraves para o estabelecimento pleno de plantios maciços de mogno consiste no aparecimento de pragas, sobretudo da Hypsipyla grandella Zeller (Lepidoptera: Pyralidae), considerada a principal praga da espécie. Por conta disso, estudos a respeito da sanidade do mogno estão concentrados nesse inseto e outros organismos danosos praticamente não têm sido relatados e são, muitas vezes, subestimados. Com base nisso, esse trabalho teve como objetivo principal buscar agentes de biocontrole da $H$. grandella, e avaliar quais espécies de ácaros e fungos ocorrem em mogno nas condições do Distrito Federal. O trabalho está dividido em oito capítulos. No primeiro capítulo, frutos de mogno foram analisados quanto à predação por $H$. grandella, revelando que muitos dos frutos caídos coletados foram atacados e consumidos pelo inseto. No segundo capítulo, um método de criação da $H$. grandella com o uso de sementes de mogno foi estabelecido, de forma a fornecer insetos para bioensaios seletivos. No terceiro capítulo, um isolado do fungo entomopatogênico Beauveria bassiana (Bals.) Vuill foi caracterizado e testado quanto a sua patogenicidade em lagartas de $H$. grandella, com $70 \%$ de mortalidade. Já no quarto capítulo, estirpes de Bacillus thuringiensis Berliner foram testadas para averiguar a sua toxicidade em lagartas de $H$. grandella e determinar a $\mathrm{CL}_{50}$ das melhores estirpes e de toxinas Cry individuais. Os resultados indicaram haver sinergismo entre essas toxinas. No quinto capítulo, as melhores estirpes dos bioensaios foram utilizadas de forma sistêmica em mudas de mogno para averiguar o potencial endofítico da bactéria e o quanto ela pode causar mortalidade em lagartas através da aplicação no solo. 
Nesse capítulo, uma estirpe em especial (S1905) teve uma eficiência de 88\% para o controle da $H$. grandella de forma sistêmica. No sexto capítulo são apresentadas duas novas ocorrências de ácaros plantícolas associados ao mogno no mundo (Aceria sp. e Eutetranychus banksi McGregor), com a apresentação de uma nova espécie de Eriophyidae. No sétimo capítulo foi verificada a ocorrência de fungos em sementes de mogno coletadas em Brasília e um fungo patogênico foi encontrado, Fusarium oxysporum Schlecht. Por fim, no oitavo capítulo, dois novos fungos foliares são descritos para o mogno, Phomopsis sp. e Phyllosticta swieteniae Garcia. Esse trabalho mostrou que o mogno, apesar de tão conhecido, é pouco estudado quanto a sua sanidade e que muitos organismos estão associados a essa espécie, podendo, muitos deles, serem específicos. Além disso, novas formas de controle são apresentadas para a $H$. grandella, sua principal praga, de forma a reduzir a pressão do uso de produtos químicos e incorporar o seu uso em programas de manejo integrado.

Palavras-chave: broca-do-mogno, biocontrole, Bacillus thuringiensis, Beauveria bassiana, ácaros plantícolas, fungos fitopatogênicos. 


\section{GENERAL ABSTRACT}

Mahogany (Swietenia macrophylla King) is a forest species appreciated by the quality of its woods, silvicultural plasticity and ornamental beauty. Your cut in natural areas was so abusive that currently is a protected and endangered species. Nevertheless, mahogany cultivation has been established in various parts of the world, including Brazil, both in commercial plantations, and the plantation of trees in several cities. However, a major obstacle to the full establishment of mahogany massive plantations is the appearance of pests, particularly the Hypsipyla grandella Zeller (Lepidoptera: Pyralidae), a major pest of the species. Because of this, studies about the sanity of mahogany are concentrated in this insect and other harmful organisms have hardly been reported and are often underestimated. Based on this, this work aimed to conduct studies regarding $H$. grandella, especially as its control using biocontrol agents and describe the main harmful organisms associated with the species in Distrito Federal, Brazil. This work is divided into eight chapters. In the first chapter, mahogany fruits were analyzed about the predation by $H$. grandella, revealing that many of the collected fallen fruits were attacked and eaten by the insect. In the second chapter, a method of creating $H$. grandella using mahogany seeds was established in order to provide insects for selective vioassays. In the third chapter, an isolate of the entomopathogenic fungus Beauveria bassiana (Bals.) Vuill was characterized and tested about your pathogenicity in $H$. grandella caterpillars, with $70 \%$ of mortality. In the fourth chapter, strains of Bacillus thuringiensis Berliner were tested to determine their toxicity in $H$. grandella caterpillars and determine the $\mathrm{LC}_{50}$ of the best strains and the individual toxins Cry. The results showed synergism between these toxins. In the fifth chapter, the best strains of bioassays were used systemically in mahogany seedlings to determine the potential of endophytic bacteria and how it can cause mortality in caterpillars when applied in the soil. In this chapter, a strain in particular (S1905) had $88 \%$ of efficiency to control $H$. grandella systemically. The sixth chapter presents two 
new occurrences of plant inhabiting mites associated with mahogany worldwide (Aceria sp. and Eutetranychus banksi McGregor), with the presentation of a new Eriophyidae. In the seventh chapter, the occurrence of fungi in mahogany seeds collected in Brasilia was verified and a pathogenic fungus was found, Fusarium oxysporum Schlecht. Finally, in the eight chapter two new foliar fungi are described for mahogany, Phomopsis sp. and Phyllosticta swieteniae Garcia. This work has shown that mahogany, although as known, is little studied about your sanity and many organisms are associated with this species, and may many of them to be specific. Moreover, new forms of control are presented to H. grandella, a major pest of mahogany, in order to reduce the pressure of use of chemicals and incorporate their use in integrated pest management programs.

Keywords: mahogany shoot borer, biocontrol, Bacillus thuringiensis, Beauveria bassiana, phytophagous mite, pathogenic fungi. 


\section{INTRODUÇÃO GERAL}

O mogno (Swietenia macrophylla King) é uma das espécies florestais de maior valor comercial no Brasil e no mundo, devido à qualidade e beleza de sua madeira, sendo considerada como nobre ou "madeira de lei” em muitos países. Por esse motivo, o mogno foi imensamente explorado e entrou para a lista de espécies ameaçadas de extinção. Para sua exploração é necessário ter a emissão de licença CITES - Convenção Internacional sobre Espécies Ameaçadas de Extinção. A partir de 2008, através do Diário Oficial da União, foi publicado o Decreto ${ }^{\circ}$ 6.472, onde fica proibido o abate de árvores de mogno, inclusive em áreas nas quais seja autorizada a supressão de vegetação (Brasil, 2008).

De acordo com Felfili e Mazzei (2001), o mogno foi amplamente plantado na região de Brasília e seu entorno, pelo Departamento de Parques e Jardins do Governo do Distrito Federal, formando, muitas vezes, grandes bosques urbanos. As árvores mais velhas foram plantadas há mais de cinquenta anos, na Esplanada dos Ministérios (Machado et al., 1992). Ainda segundo os autores, o desenvolvimento das árvores tem sido satisfatório, com algumas ultrapassando 20 metros de altura e $60 \mathrm{~cm}$ de diâmetro. Com relação ao aproveitamento de madeira, grande parte das árvores apresenta o fuste sem bifurcações até os quatro metros de altura, o que indica um elevado potencial da espécie para a produção moveleira na região do Distrito Federal e entorno. Porém, a falta de conhecimentos sobre os problemas fitossanitários é a principal barreira existente para a produção comercial da espécie. Estudos sobre a sua fitossanidade na região do Distrito Federal são praticamente inexistentes, limitando-se apenas a poucos relatos de ocorrência de sua principal praga, a Hypsipyla grandella Zeller (Lepidoptera: Pyralidae). Além disso, pouco se conhece sobre a bioecologia da H. grandella na região do Planalto Central, não se sabe, por exemplo, qual é o período de maior ataque, informação essencial para o seu controle. 
Assim, devido a sua elevada importância, o interesse de se realizar pesquisas com o objetivo de preservar, conservar e garantir o uso sustentável do mogno é evidente, sendo necessárias pesquisas com o intuito de diminuir os prejuízos pela $H$. grandella e também investigar quais são os principais organismos danosos associados à espécie. 


\section{OBJETIVOS}

\section{Objetivo geral}

Buscar agentes de biocontrole da principal praga do mogno, Hypsipyla grandella Zeller, e avaliar quais espécies de ácaros e fungos ocorrem em mogno nas condições de Brasília, Distrito Federal.

\section{Objetivos específicos}

Quantificar os danos provocados pela H. grandella em frutos de mogno;

Estabelecer uma metodologia eficaz para a criação de H. grandella;

Levantamento de novos agentes de biocontrole contra $H$. grandella;

Realizar bioensaios de mortalidade de $H$. grandella com estirpes de Bacillus thuringiensis Berliner;

Avaliar o potencial de estirpes de B. thuringiensis para controlar H. grandella de forma sistêmica em mudas de mogno;

Descrever os principais organismos danosos associados ao mogno, assim como seus possíveis sintomas, durante a produção de mudas em casa de vegetação e em árvores de Brasília;

Avaliar a sanidade de sementes de mogno em laboratório e em casa de vegetação. 


\section{REVISÃO BIBLIOGRÁFICA}

\section{Mogno: aspectos taxonômicos, ecológicos, silviculturais, econômicos e fitossanitários}

A família Meliaceae possui vários representantes economicamente importantes, sobretudo na indústria madeireira. Com 51 gêneros e aproximadamente 1400 espécies descritas no mundo (Pinheiro, 2000), alguns gêneros se destacam no mercado comercial internacional, como o mogno verdadeiro (Swietenia spp.), mogno africano (Khaya spp.), cedro americano (Cedrella spp.), cedro australiano (Toona spp.) e andiroba (Carapa spp.). As árvores dos gêneros Swietenia, Khaya e Entandrophragma são tradadas como mogno (“mahogany") em diversas partes do mundo. Existem três espécies válidas dentro do gênero Swietenia: S. macrophylla King, com ocorrência natural no México, América Central e América do Sul (Figura 1); S. mahagoni (L) Jacq., nativa dos Estados Unidos da América e das Antilhas; e S. humilis Duce, distribuída ao longo da Costa do Pacífico (Mohanadas, 2000).

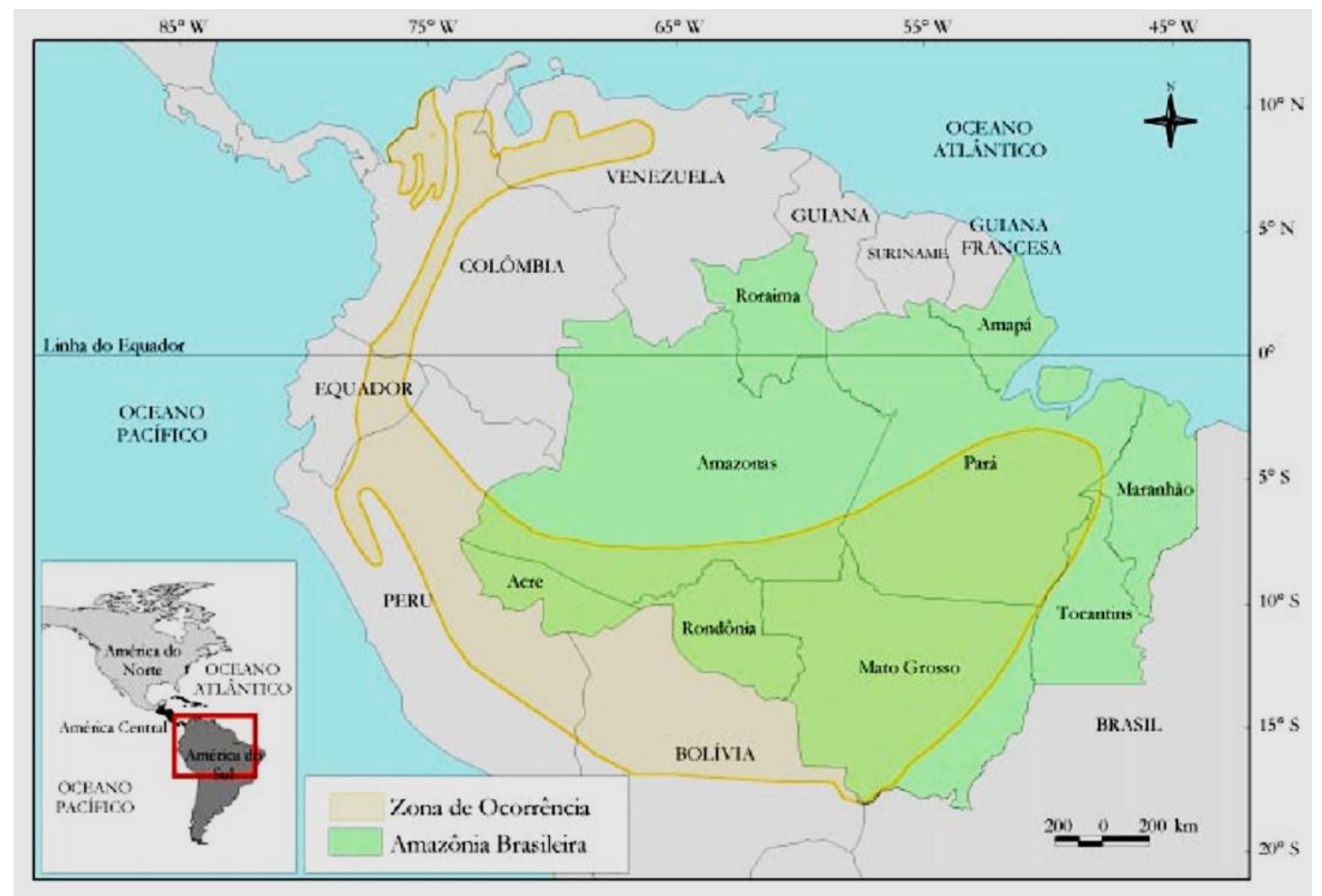

Figura 1. Zona de ocorrência de Swietenia macrophylla na América do Sul, abrangendo seis países: Venezuela, Colômbia, Equador, Peru, Bolívia e Brasil (Grogan et al., 2002). 
O mogno brasileiro (S. macrophylla) é uma árvore robusta que geralmente domina o dossel de uma floresta e é considerada uma espécie decídua a semidecídua, podendo atingir uma altura total de 70 metros, com média de 30 a 40 metros, e 3,5 metros de diâmetro (Williams, 1932; Lamb, 1966; Pennington \& Sarukhán, 1968). As raízes tabulares são comuns e, em alguns casos, atingem até cinco metros na base. $\mathrm{O}$ tronco é espesso, com sulcos profundos e casca quase preta, o que proporciona uma excelente resistência ao fogo (Lamb, 1966; Chudnoff, 1979). É uma espécie extremamente apreciada na fabricação de móveis, decoração e no uso paisagístico. Sua madeira é moderadamente pesada, dura, com cerne castanho-amarelado e textura fina a média, sendo utilizada em peças torneadas, objetos de decoração, instrumentos científicos de precisão, instrumentos musicais, esculturas, talhados, móveis, laminados, compensados, carpintaria, construção naval e indústria de aviação (Lorenzi, 1992). A valorização da madeira se deve a sua cor atrativa, estabilidade dimensional, durabilidade, fácil manuseio e utilização pela indústria (Rizzini, 1990). A madeira do mogno possui densidade básica (peso seco em estufa / volume verde) de 0,45 $\mathrm{kg} / \mathrm{cm}^{3}$, contração tangencial de $4,1 \%$, contração radial de $3,0 \%$ e contração volumétrica de 7,8\% (Melo et al., 1989).

O cultivo de $S$. macrophylla está estabelecido em mais de 40 países ao redor do mundo, principalmente nas áreas úmidas e subúmidas dos trópicos no sul e sudeste da Ásia, nas ilhas do Pacífico, no Caribe e na África tropical (CABI, 2005). Segundo Pandey (1983), em 1980 havia cerca de 55.000 hectares de plantios de S. macrophylla no mundo. Já em 1995, as plantações da espécie cobriram aproximadamente 151 mil hectares (Pandey, 1997). Na Indonésia há mais de 55 mil hectares plantados (Cossalter \& Nair, 2000) e nas Ilhas Fiji aproximadamente 26 mil hectares (Kamath et al., 1996), figurando, assim, como os países que mais plantam o mogno. No Brasil, não há dados sobre o número exato de plantios maciços de mogno, apenas alguns relatos de cultivo no Norte do país, principalmente no Pará e no 
Centro-Oeste e Sudeste, sobretudo Goiás, Minas Gerais e São Paulo. Tentativas do cultivo de mogno fora de sua área de origem foram consideradas um fracasso devido às mudas de baixa qualidade e a incidência de Hypsipyla grandella Zeller (Carvalho, 2007).

A produção de mudas de mogno é relativamente simples. As sementes possuem alta taxa de germinação, podendo chegar até $100 \%$ quando frescas. O plantio das mudas deve ser no período chuvoso, que é fundamental para garantir o bom crescimento das mudas até o próximo período de estiagem, onde a sobrevivência tende a ser reduzida. Sob condições de sombreamento, o crescimento da espécie tende a ser reduzido em até $50 \%$ em relação aos plantios em pleno sol. A partir dos oito anos de idade apresenta crescimento rápido, incrementos em diâmetro e abertura da copa no período que corresponde ao início da frutificação (Yared \& Carpanezzi, 1981).

O crescimento do mogno varia de lento a moderado. Estima-se uma rotação entre 40 a 60 anos, mas as árvores poderão ser aproveitadas a partir dos 25 anos, com aproximadamente 20 metros de altura e com DAP de $70 \mathrm{~cm}$. Sua madeira é extremamente valorizada e com alta demanda para exportação, onde o seu valor no mercado é de $\mathrm{R} \$ 5$ mil por $\mathrm{m}^{3}$, sendo que a madeira extraída ilegalmente é vendida por $\mathrm{R} \$ 125$ por $\mathrm{m}^{3}$, o que levou a exploração desordenada que chegou nos últimos 10 anos a 4 milhões de $\mathrm{m}^{3}$ de mogno nativo (Carvalho, 2007). Na década de 90, o Brasil contribuiu com cerca de $60 \%$ do volume de mogno comercializado, seguido da Bolívia com 27,6\%. Desse total, 50\% foram enviados para os Estados Unidos da América, 34,3\% à Comunidade Européia e 23,3\% ao Reino Unido (Funatura, 1993).

O mogno tem sido amplamente utilizado na arborização urbana, sobretudo em Brasília, Distrito Federal e em Manaus, Amazonas (Prance \& Silva, 1975). O mogno está entre as espécies mais utilizadas na arborização urbana de Brasília (Jacinto, 2001), com destaque para a formação de florestas urbanas, onde é recomendado o plantio consorciado 
como uma das formas de prevenir o ataque da $H$. grandella. O mogno foi introduzido em Brasília pelo paisagista Burle Marx, sobretudo nas superquadras 315 e 316 da Asa Norte do Plano Piloto. A espécie predomina quase toda a área verde dessas quadras, formando um pequeno bosque, com indivíduos que ultrapassam a altura de um prédio de seis andares (Carvalho, 2007; Lima, 2009). No Campus Darcy Ribeiro da Universidade de Brasília existem mais de 90 indivíduos de S. macrophylla (Kurihara \& Imaña-Encinas, 2003). As árvores de Brasília mostraram que a espécie apresentou um crescimento primário e secundário bastante satisfatório, sendo passível de ser plantada de forma comercial e também na sua utilização em consórcios com outras espécies e em sistemas agroflorestais.

Com relação a sua sanidade, insetos das Ordens Hemiptera, Lepidoptera, Coleoptera, Isoptera e Hymenoptera já foram reportados associados ao mogno (Tabela 1), além das espécies do gênero Hypsipyla (Lepidoptera). Porém, a maior parte deles não causa grandes danos. Nenhuma espécie de ácaro foi descrita associada a $S$. macrophylla até o presente momento.

Em florestas naturais da Bolívia, as mudas de mogno são atacadas por formigas das espécies Atta cephalotes e Atta cf. sexdens (Larrea, 1999). Essas espécies atacam também plantações de mogno. Kamath et al. (1996) estimaram que cupins atacaram 7,7\% das árvores de mogno em uma plantação realizada no Fiji. No Sri Lanka e nas Ilhas Salomão, espécies do gênero Coptotermes atacaram árvores vivas de mogno (Mayhew \& Newton, 1998). Não há relato de ataque de cupins em outros países. Alguns insetos da ordem Coleoptera também já foram reportados em plantações de mogno, porém com menor importância econômica (Nair, 2007). 
Tabela 1. Insetos associados ao mogno no mundo, com excessão da Hypsipyla spp. [extraído de Mohandas (2000), com modificações]:

\begin{tabular}{ccc}
\hline Inseto & País & Referência \\
\hline Ambleypelta cocophaga (Hemiptera) & Ilhas Salomão & Oliver (1992) \\
Egchiretes nominus (Lepidoptera) & Belize, Honduras & Chable (1967) \\
Diaprepes abbreviatus (Coleoptera) & Porto Rico & Bauer (1987) \\
Dysercus longiclaris (Coleoptera) & Malásia & Ata \& Ibrahim (1984) \\
Catopyla dysorphnaea (Coleoptera) & - & Brunck \& Mallet (1993) \\
Gyroptera robertsii (Coleoptera) & - & Brunck \& Mallet (1993) \\
Crossotarsus externe-dentatus (Coleoptera) & Fiji & Roberts (1977) \\
Platypus gerstaeckeri (Coleoptera) & Fiji & Roberts (1977) \\
Coptotermes sp. (Isoptera) & Fiji & Oliver (1992) \\
Neotermes samoanus (Isoptera) & Sri Lanka & Stevenson (1940) \\
Neotermes papua (Isoptera) & Ilhas Salomão & Kamath et al. (1993) \\
Procryptotermes spp. (Isoptera) & Belize & Kamath et al. (1995) \\
Atta spp. (Hymenoptera) & Bolívia & Larrea (1999) \\
\hline
\end{tabular}

Estudos sobre doenças que acometem a cultura são incipientes e doenças foliares praticamente não tem sido observadas no Brasil. A principal doença relatada em mogno é a "queima-de-Cylindrocladium", causada pelo fungo Cylindrocladium sp., detectada em folhas de mogno em plantio florestal para recuperação de áreas degradadas na Amazônia (Gasparotto et al., 2014). As folhas infectadas apresentam queima das bordas, que progridem em direção à nervura central. Sclerotium coffeicola Bull., agente causal da mancha-zonada, já foi relatado em mogno nos estados do Pará (Bastos, 1998) e do Amazonas (Assis et al., 2007). Além dessas doenças, já foram relatadas várias espécies do gênero Meliola (Assis et al., 2010), Cylindrocladium floridanum Sobers \& Seym (Mendes et al., 1998), Colletotrichum gloeosporoides (Penz.) Sacc. (Trindade et al., 2004), Erythricium salmonicolor (Berk. et. Br.) Burds (Hadi et al., 1993) e Gloeosporium sp., que causa manchas foliares (Suharti \& Irianto, 
1992). Avaliações fitossanitárias e aspectos patológicos de fungos encontrados em sementes de mogno nunca foram realizados.

\section{Hypsipyla grandella (Lepidoptera: Pyralidae): biologia, criação e formas de controle}

O gênero Hypsipyla é composto por 11 espécies, dentre as quais cinco se destacam por atacar árvores de interesse econômico, sobretudo representantes da família Meliaceae. Segundo Bradley (1968), H. robusta Moore é encontrada na África, Ásia e Austrália, H. ferrealis Hampson na América Central e norte da América do Sul, H. grandella na América Central e América do Sul, H. albopartalis Hampson e H. areboruna Meiryck na África. $H$. robusta ataca os gêneros Khaya, Toona e Entandrophragma e $H$. grandella os gêneros Swietenia, Cedrella e Carapa. Essas duas espécies são consideradas as principais pragas dentro do gênero (Grijpma, 1974).

Hypsipyla grandella, também conhecida como broca-das-meliáceas, é um inseto que possui um ciclo biológico de aproximadamente 30 dias, dos quais o período larval compreende 20 dias e o período pupal 10 dias, com temperatura de $30^{\circ} \mathrm{C}$ (Vargas et al., 2001; Taveras et al., 2004). Uma única fêmea fertilizada pode pôr de 33 a 200 ovos durante três a quatro dias (Grijpa, 1971; Berti Filho, 1973; Sarmento Júnior, 2001; Ohashi et al., 2002; Silva, 2003) e até mais de 1000 ovos em toda a sua vida, em condições de laboratório (Grijpma \& Roberts, 1976).

Dentro da família Meliaceae, 13 gêneros são alvos de $H$. grandella. No Brasil, ocorrem em mogno, cedro (Cedrella odorata L.) e andiroba (Carapa guianensis Aubl.), atacando ramos, brotos, folhas, frutos, casca (Taveras et al., 2004) e até mesmo a raiz (Yamazaki et al., 1990).

Estudos a respeito da capacidade de voo e colonização de novos ambientes foram realizados por Fasoranti et al. (1982), comprovando que H. grandella possui uma grande 
capacidade de voo e dispersão, podendo alcançar até 10 quilômetros de distância do ponto de origem, além de conseguir localizar facilmente um hospedeiro isolado. Apesar disso, as mariposas permanecem na área atacada enquanto novas brotações ainda estiverem presentes, causando dano local severo (Griffiths, 2001). Os adultos são geralmente atraídos por árvores jovens, emitindo novas folhagens, e por árvores danificadas e com presença de fezes. Os ovos são colocados nas brotações, ramos ou folhas, geralmente na superfície dorsal das folhas (Grijpma \& Gara, 1970; Griffiths, 2001).

O principal dano do inseto em árvores de mogno consiste na destruição do broto terminal em mudas e árvores novas, devido à entrada e escavação de galerias pelas lagartas (Grijpma, 1976). Os sintomas do ataque da lagarta são representados por exsudação de goma e serragem, presença de folhas secas em meio à folhagem verde e emissão de novos ponteiros a cada ataque consecutivo, que posteriormente também serão atacados (Silva, 1985; Griffiths, 2000, Ohashi et al., 2002). O crescimento de um tronco retilíneo é fortemente prejudicado (Grijpma, 1976; Ohashi et al., 2000), com perda em altura de até 35\% nos primeiros anos (Ohashi et al., 2002). Ataques repetitivos e intensos podem causar a morte da planta.

A criação do inseto a base de uma dieta artificial é relativamente difícil. Estudos baseados em diferentes dietas adaptadas de outros lepidópteros foram realizados, porém as lagartas ficaram pequenas e com baixo peso, as pupas deformadas e os adultos inférteis (Vargas et al., 2001). Com isso, a criação é baseada primordialmente no uso de folhas frescas de mogno e de andiroba.

Em uma recente revisão feita por Lunz et al. (2009), os principais métodos de controle pesquisados para o controle da broca são: uso de genótipos resistentes ao inseto; manejo silvicultural por meio da interferência na localização da planta hospedeira, redução da adequabilidade hospedeira, aumento de inimigos naturais e recuperação da forma e incremento da altura da planta; uso de semioquímicos; e o controle biológico, com o uso de 
fungos, vespas, nematoides e bactérias. O uso de inseticidas convencionais tem sido desaconselhável para o controle da broca por razões como o hábito do inseto (críptico), a natureza dos danos (internos na planta), fatores climáticos (pluviosidade intensa na região de ocorrência natural) e o longo período de proteção necessário que perdura quase todo o ciclo de vida da planta, que o torna oneroso, impraticável e danoso para o meio ambiente (Wylie, 2001; Mahroof et al., 2002).

Devido à importância que a $H$. grandella possui como inseto danoso ao mogno, essa espécie foi escolhida como chave para a realização dos estudos desse trabalho. Portanto, foi dada maior atenção a essa praga no que se refere aos danos em mogno, criação e, sobretudo, na busca de um agente de biocontrole eficaz. Até o presente momento, não existem estratégias para se controlar de forma eficaz e plena a incidência de $H$. grandella sobre as meliáceas de importância comercial (Lunz et al., 2009). Surge, então, um promissor meio de controle de $H$. grandella, a bactéria Bacillus thuringiensis Berliner, um agente de controle biológico muito utilizado para controlar diversas pragas agrícolas e florestais.

\section{Microrganismos como agentes de biocontrole de pragas}

Bacillus thuringiensis é uma bactéria gram positiva, aeróbia, da família Bacillaceae, de abrangência cosmopolita (Krywunczyk \& Fast, 1980), podendo ser encontrada em vários substratos como solo, água, superfície de plantas, insetos mortos, teias de aranha e grãos armazenados (Bravo et al., 1998). De acordo com Habib \& Andrade (1998), Bt possui características bacteriológicas típicas e que diferem das outras espécies dentro do gênero, como a formação de esporos de formato elípticos a cilíndricos, geralmente em posição central, com um esporângio não nitidamente estendido.

Com relação ao seu ciclo de vida, o $B t$ apresenta duas fases principais: uma de crescimento vegetativo, na qual a bactéria se multiplica por bipartição e outra de esporulação, 
que consiste na diferenciação da bactéria em esporo (Soberon \& Bravo, 2001). No momento de sua esporulação, há a produção de inclusões protéicas cristalinas, de formas definidas, que podem ser visualizadas por microscopia de contraste de fases (Monnerat \& Bravo, 2000). A atividade entomopatogênica dessa bactéria se deve justamente a essas inclusões protéicas, que são cristais compostos por proteínas denominadas endoproteínas ou proteínas cristal (Bravo et al., 1998; Monnerat \& Bravo, 2000).

O uso de $B t$ no biocontrole de insetos-praga apresenta muitas vantagens como a sua especificidade aos insetos alvo, possui efeito não poluente ao meio ambiente, inocuidade aos mamíferos e vertebrados e ausência de toxicidade às plantas, o que permite a sua aplicação direta (Whiteley \& Schnepf, 1986). Segundo Quesada-Moraga et al. (2004), esse organismo tem merecido atenção pelos pesquisadores por controlar larvas/lagartas/ninfas de insetos das ordens Lepidoptera, Diptera, Coleoptera, Orthoptera e Hemiptera, além de outros organismos, como ácaros, nematoides e protozoários.

As toxinas produzidas por $B t$ estão divididas em quatro grupos principais: $\alpha$ exotoxina, $\beta$-exotoxina, VIP3A e $\delta$-endotoxina. A $\alpha$-exotoxina, também conhecida como fosfolipase C, lectinase ou fosfatidilcolina fosfohidrolase (Toumanoff, 1952; Faust \& Bulla Jr., 1982), é uma enzima que possui atividade citolítica ao atuar sobre os fosfolipídeos que formam as membranas de diversos tipos celulares (Faust \& Bulla Jr., 1982). É uma toxina termolábil, solúvel em água, altamente tóxica para alguns insetos e vertebrados, encontrada no sobrenadante de algumas culturas durante a fase logarítmica de crescimento de certas estirpes de Bt, causando a degeneração e a lise de hemócitos (Krieg, 1971; Habib \& Andrade, 1998; Hansen \& Salamitou, 2000). O gene correspondente a essa toxina foi clonado e sequenciado (Lechner et al., 1989).

Descrita por Heimpel em 1967, a $\beta$-exotoxina é termoestável em água, altamente tóxica para muitos insetos e certos vertebrados (Habib \& Andrade, 1998), produzida durante a 
fase vegetativa de crescimento de algumas subespécies de Bt. O termo sugerido por Heimpel foi considerado inadequado para essa substância, devido a sua estrutura química. Assim, o termo thuringiesina foi sugerido por vários autores (Kim \& Huang, 1970; Pais \& De Barjac, 1974; Farkas et al., 1977). Por não afetar apenas invertebrados, a utilização dessa toxina é limitada e proibida em diversos países (Sebesta \& Horska, 1968; De Barjac \& Riou, 1969). Nenhuma das estirpes usualmente utilizadas no Laboratório de Bactérias Entomopatogênicas da Embrapa Recursos Genéticos e Biotecnologia produzem essa toxina, o que as tornam específicas contra os insetos alvo.

A VIP3A, do inglês vegetative insecticidal proteins, é uma proteotoxina que foi identificada como sendo do sobrenadante de culturas de algumas estirpes de $B t$, em fase logarítmica de crescimento (Estruch et al., 1996; Yu et al., 1997). Assim, o uso do sobrenadante também é aproveitado, e não apenas a mistura de esporos e cristais obtida após o cultivo de Bt (Monnerat \& Praça, 2006). Estudos tem apresentado que essa toxina tem atividade contra insetos pouco sensíveis à maioria das $\delta$-endotoxinas (Bravo et al., 1998; Monnerat \& Bravo, 2000).

Conhecidas também como proteínas Cry, as $\delta$-endotoxinas participam da formação do cristal protéico, ligado a esporulação da bactéria, formado a partir do segundo estágio da esporulação e é liberado quando as células são lisadas (Monnerat \& Bravo, 2000). De acordo com Crickmore et al. (1998), a classificação dessas proteínas é baseada na similaridade das sequências de aminoácido. Atualmente existem mais de 700 diferentes genes Cry e as proteínas Cry estão agrupadas em 73 classes. A atualização constante desta nova classificação se encontra disponível no site: http://www.lifesci.sussex.ac.uk/home/Neil_Crickmore/Bt/. Essas proteínas são as mais utilizadas para o biocontrole de insetos e apresentam um espectro de ação, normalmente, restrito a uma Ordem de insetos em particular (De Maagd et al., 2001). Apresentam ação extremamente tóxica (Valadares-Inglis et al., 1998) para 
larvas/lagartas/ninfas de insetos das ordens Lepidoptera, Coleoptera, Diptera, Hymenoptera, Hemiptera e Orthoptera.

O mecanismo de ação das proteínas Cry pode ser dividido em sete etapas: 1) Solubilização do cristal, onde o pH alcalino e as condições redutoras do intestino médio do inseto são indispensáveis para esse processo; 2) Processamento das toxinas, onde há a participação das proteases predominantes do intestino médio (tripsina, quimiotripsina, termosilina e cartepsinas); 3) União ao receptor, podendo ser do tipo reversível ou irreversível. A união aos sítios é a etapa determinante da alta especificidade das $\delta$-endotoxinas (Van Rie et al., 1989); 4) Inserção na membrana, onde a fase irreversível da união das $\delta$ endotoxinas na membrana é considerada como uma evidência de que as proteínas Cry inserem-se na membrana para, em seguida, causar a destruição do tecido intestinal das larvas/lagartas de insetos suscetíveis (Van Rie et al., 1989; Liang et al., 1995); 5) Agregação, na qual o modelo propõe que o poro é formado por 4-6 moléculas; 6) Formação do poro, com um diâmetro de 1 a $2 \mathrm{~nm}$; 7) Citólise, causada por efeitos sinergéticos dos cristais e esporos. Foi demonstrado que as proteínas Cry causam a morte das células epiteliais ao inativar o sistema que mantém o gradiente de $\mathrm{pH}$ (Wolfersberger, 1992) e por citólise osmótica (Knowles \& Ellar, 1987). A consequência final da destruição do intestino médio e a proliferação de bactérias na hemolinfa é a morte das larvas/lagartas por inanição e septicemia (Monnerat \& Praça, 2006).

O uso de $B t$ ocupa de 1 a $2 \%$ do mercado de produtos usados como inseticidas de pragas agrícolas, florestais ou de vetores de doenças para o homem e animais (Estruch et al., 1996; Baum et al., 1999), conferindo níveis adequados e consistentes de controle. No Brasil, para que os produtos biológicos possam ser utilizados em grande escala, é necessário que sejam produzidos bioinseticidas nacionais com preços mais acessíveis e que possam competir com os produtos químicos. Além disso, precisam ser altamente eficientes para ter uma boa 
aceitação por parte dos produtores e consequentemente, maior demanda. Para a correta utilização destes produtos, é necessário que os agricultores ou responsáveis técnicos conheçam as características da cultura e, principalmente, a biologia do inseto alvo, assim como também as recomendações para a aplicação adequada do produto (Praça et al., 2007).

Os fungos entomopatogênicos pertencem a aproximadamente 90 gêneros e 700 espécies (Alves, 1998). Beauveria bassiana (Balsamo) Vuill e Metarhizium anisopliae Sorok são fungos mitospóricos cosmopolitas frequentemente encontrados na natureza e representam as espécies mais estudadas como agentes de controle biológico de insetos-praga desde o século XIX (Tigano \& Mello, 2006). Isolados desses fungos podem ser obtidos tanto de seus hospedeiros quanto de amostras de solo. A identificação de espécies é baseada em critérios morfológicos e moleculares (Alves, 1998; Humber, 1997; Goettel \& Inglis, 1997; Tigano \& Mello, 2006).

Os fungos que causam mortalidade em insetos têm grande versatilidade e podem infectar diferentes estágios de desenvolvimento dos hospedeiros. Infectam seus hospedeiros penetrando através do tegumento, por via oral, anal, entre outras formas. Segundo Alves (1998), os sinais das doenças produzidas por B. bassiana em insetos são caracterizados inicialmente pela interrupção da alimentação e desorientação, posteriormente aparecem hifas através dos espiráculos e, finalmente, pela presença do micélio que envolve externamente o cadáver do inseto, dando o aspecto de algodão, de cor branca.

Os fungos $B$. bassiana e $M$. anisopliae apresentam baixa toxicidade e não infectam mamíferos. Experimentos em campo demonstraram que esses fungos não representam riscos para o meio ambiente quando introduzidos como biopesticidas, pois não afetam a microflora e a fauna nativa (Hu \& St. Leger, 2002; Ivie et al., 2002; Wang et al., 2004). O gênero Beauveria é um dos mais promissores agentes de biocontrole de pragas, pois é de fácil 
dispersão, possui grande variedade de hospedeiros e habilidade de penetrar via cutícula (Samish \& Glazer, 1991).

Alguns microrganismos já foram isolados de lagartas de Hypsipyla spp. (Tabela 2), inclusive isolados de Beauveria. Apesar de uma ampla gama de possíveis agentes de biocontrole ter sido descoberta associados ao inseto, poucos estudos foram realizados com o propósito de verificar o potencial destes para o controle da Hypsipyla.

São poucas as pesquisas relacionadas ao uso de $B t$ e $B$. bassiana para o controle de $H$. grandella. Em uma revisão feita por Lunz et al. (2009), o uso de Bt na cultura do mogno está restrita a aplicação antes da penetração das lagartas nos ramos. Porém, nenhum estudo aprofundado sobre as principais toxinas Cry envolvidas na mortalidade da lagarta, assim como o possível efeito sistêmico que $B t$ pode ter em plantas de mogno, foi realizado. O mesmo acontece com o uso de fungos entomopatogênicos para o controle da broca do mogno. Portanto, este trabalho visa contemplar e minimizar uma lacuna importante relacionada ao estudo de organismos danosos ao mogno e lançar estratégias de controle da $H$. grandella de forma efetiva e menos danosa ao meio ambiente, o uso de agentes biológicos. 
Tabela 2. Microrganismos tóxicos a Hypsipyla robusta e Hypsipyla grandella [extraído de Hauxwell \& Floyd (2001), com adaptações]:

\begin{tabular}{|c|c|c|c|}
\hline Patógeno & Local & Espécie & Referência \\
\hline Fungos & & & \\
\hline Beauveria bassiana & Desconhecido & H. grandella & $\begin{array}{l}\text { Berrios \& Hidalgo- } \\
\text { Salvatierra (1973a) }\end{array}$ \\
\hline Beauveria bassiana * & Brasil & H. grandella & Barbosa et al. (2012) \\
\hline Beauveria sp.* & Peru & H. grandella & Yamazaki et al. (1990) \\
\hline B. brongniartii * & Índia & H. robusta & Kandasamy (1969) \\
\hline B. brongniartii $*$ & Desconhecido & H. grandella & $\begin{array}{l}\text { Berrios and Hidalgo- } \\
\text { Salvatierra (1973b) }\end{array}$ \\
\hline B. brongniartii * & Índia & H. robusta & Misra (1993) \\
\hline Metarhizium anisopliae & Desconhecido & H. grandella & $\begin{array}{l}\text { Berrios \& Hidalgo- } \\
\text { Salvatierra (1973a) }\end{array}$ \\
\hline Metarhizium sp. * & Costa Rica & H. grandella & Hauxwell et al. (n/p) \\
\hline Metarhizium sp. * & Gana & H. robusta & Hauxwell et al. (n/p) \\
\hline Cordyceps sp. * & Trinidad & H. grandella & Myers (1935) \\
\hline $\begin{array}{c}\text { Bactéria } \\
\text { Bacillus thuringiensis }\end{array}$ & Desconhecido & H. grandella & $\begin{array}{c}\text { Hidalgo-Salvatierra \& } \\
\text { Palm (1973) }\end{array}$ \\
\hline $\begin{array}{c}\text { Nematoides } \\
\text { Hexamermis sp. * }\end{array}$ & Índia & H. robusta & $\begin{array}{c}\text { Chatterjee \& Singh } \\
\text { (1965) }\end{array}$ \\
\hline Hexamermis sp. * & Índia & H. robusta & Rao (1969) \\
\hline Hexamermis sp. * & Peru & H. grandella & Yamazaki et al. (1990) \\
\hline Hexamermis sp. * & Nigéria & H. robusta & Roberts (1965) \\
\hline Hexamermis albicans * & Costa Rica & H. grandella & $\begin{array}{c}\text { Nickle \& Grijpma } \\
\text { (1974) }\end{array}$ \\
\hline Hexamermis albicans * & Belize & H. grandella & Bennett (1968) \\
\hline Hexamermis albicans $*$ & Venezuela & H. grandella & Rao \&Bennett (1969) \\
\hline $\begin{array}{c}\text { Protozoário } \\
\text { Microsporídio * }\end{array}$ & $\begin{array}{c}\text { Costa Rica, } \\
\text { Siri Lanka, } \\
\text { Gana }\end{array}$ & $\begin{array}{l}\text { H. grandella } \\
\text { H. robusta }\end{array}$ & Hauxwell et al. (n/p) \\
\hline
\end{tabular}

Vírus 


\section{REFERÊNCIAS BIBLIOGRÁFICAS}

ALVES, S. B. 1998. Fungos entomopatogênicos. In: ALVES, S. B. et al. Controle Microbiano de Insetos. 2. ed. Piracicaba: Fealq, p. 308-310.

ASSIS, L. A. G.; COELHO NETTO, R. A.; BARBOSA, A. P. Ocorrência de mancha foliar em mogno causada por Sclerotium coffeicola no estado do Amazonas. 2007. Summa Phytopathologica, Botucatu, v. 33, n. 1, p. 99.

ASSIS, L. A. G.; COELHO NETTO, R. A.; BARBOSA, A. P.; BEZERRA, J. L.; GASPAROTTO, L.; SOUSA, F. M. G. 2010. Parasitas fúngicos em espécies florestais nativas da Amazônia Central. Agrotrópica, Ilhéus, v. 22, n. 3, p. 137-144.

ATA, A. B.; IBRAHIM, Z. B. 1984. Some notes on mahogany, especially Khaya. Rimba Indonesia, v. 5, n. 5/6, p. 266-328.

BARBOSA, P. A.; LIRA, J. L. C. B.; KOLS, D. A. de S.; THOMAZINI, M. J.; LOPES, R. B. 2012. Ocorrência natural de fungos entomopatogênicos associados à broca-do-mogno, Hypsipila grandella (Lepidoptera: Pyralidae). In: Congresso Brasileiro de Entomologia, 24, Curitiba, Anais Web. Curitiba: SEB: UFPR.

BASTOS, C. N. 1998. Mancha foliar em mogno (Swietenia macrophylla King) causada por Sclerorium coffeicolum Stahel. Agrotrópica, Ilhéus, v. 10, n. 1, p. 41-42.

BAUER, G. P. 1987. Swietenia macrophylla and S. macrophylla $\mathbf{x}$ S. mahogany development and growth: the nursey phase and the establishment phase in line planting 
in the Caribbean National Forest, Puerto Rico. MSc Thesis, College of Environmental Science and Forestry, State University of New York.

BAUM, J.A.; JOHNSON, T.B.; CARLTON, B.C. 1999. Bacillus thuringiensis. Natural and recombinant bioinsecticide products. Methods Biotechnology, v. 5, p. 189-209.

BENNET, F. D. 1968. A note on the parasites and on the seasonal abundance of Hypsipyla grandella in Britsh Honduras. Travel report, Commonwealth Institute Biological Control, Trinidad.

BERRIOS, F.; HIDALGO-SALVATIERRA, O. 1973a. Susceptibility of the larva to the fungus Metarhizium anisopliae (Metch.). In: GRIJPMA, P. (Ed.). Studies on the shoot borer Hypsipyla grandella Zeller (Lep.: Pyralidae). Vol. I, p. 61-66.

BERRIOS, F.; HIDALGO-SALVATIERRA, O. 1973b. Susceptibility of the larva to the fungi Beauveria bassiana (Bal.) and B. tenella (Del.). In: GRIJPMA, P. (Ed.) Studies on the shoot borer Hypsipyla grandella (Zeller) Lepidoptera: Pyralidae, Turrialba, v. 24, n. 4, p. 68-70.

BERTI FILHO, E. 1973. Observações sobre a biologia de Hypsipyla grandella (Zeller, 1848) (Lepidoptera, Phycitidae). Dissertação (Mestrado em Entomologia). Escola Superior de Agricultura Luiz de Queiroz, Universidade de São Paulo, Piracicaba, São Paulo. 108 f.

BRADLEY, J. D. 1968. Description of two genera and species of phycitinae associated with Hypsipyla robusta Moore on Meliaceae in Nigeria (Lepidoptera, Pyralidae). Bulletin of Entomological Research, v. 57, n. 4, p. $605-613$. 
BRAVO, A.; SARABIA, S.; LOPEZ, L.; ONTIVEROS, H.; ABARCA, C.; ORTIZ, A.; ORTIZ, M.; LINA, L.; VILLA-LOBOS, F.J.; GUADALUPE, P.NUNEZ-VALDEZ, M.E.; SOBERÓN, M.; QUINTERO, R. 1998. Characterization of cry genes in Mexican Bacillus thuringiensis strain collection. Applied Environmental Microbiology, v. 64, n.12, p. 49654972.

BRASIL, 2008. Altera o art. $3^{\circ}$ do Decreto $n^{0} 4.722$, de 5 de junho de 2003 , que estabelece critérios para exploração da espécie Swietenia Macrophylla King (mogno). Disponível em: http://www.planalto.gov.br/ccivil_03/_Ato2007-2010/2008/Decreto/D6472.htm Acessado em março de 2014.

BRUNCK, F.; MALLET, B. 1993. Problems relating to pests of mahogany in Cote d' Ivoire. Bois-et-Forest-dea-Tropiques, v. 237, p. 9-29

CABI (Commonwealth Agricultural Bureau International). 2005. Forestry Compendium, 2005 edn., CD Version. Wallingford, UK: CAB International.

CARVALHO, P. E. R. 2007. Mogno - Swietenia macrophylla. Colombo, Paraná, Embrapa Florestas. Circular Técnico 140, p. 12.

CHABLE, A. C. 1967. Reforestation in the Republic of Honduras, Central America. Ceiba, v. 13, n. 2, p. 1-56. 
CHATTERJEE, P. N.; SINGH, P. 1965. Mermithid parasites and their role in natural control of insect pests. Indian Forester, v. 97, p. 714-721.

CHUDNOFF, M. 1979. Tropical Timbers of the World. US Forest Products Laboratory, USDA Forest Service, Madison, WI, USA, 831 p.

COSSALTER, C.; NAIR, K. S. S. 2000. The state of the forest and plantation trends. In: Insect pests and diseases in Indoneasian forests: An assessment of the major threats, research efforts and literature, ed. K. S. S. Nair. Bogor, Indonesia: Center for International Forestry Research, p. 3-9.

CRICKMORE, N.; ZEIGLER, D.R.; FEITELSON, J.; SCHNEPF, E.; VAN RIE, J.; LERECLUS, D.; BAUM, J.; DEAN, D.H. 1998. Revision of the nomenclature of the Bacillus thuringiensis pesticidal crystal proteins. Microbiology and Molecular Biology Reviews, v .62 , p. $807-813$.

DE BARJAC, H.; RIOU, J.Y. 1969. Action de la toxine thermostable de Bacillus thuringiensis administrée à des souris. Reevue Pathology Compendium Experimental, v. 6, p. 367-374.

DE MAAGD, R.A.; BRAVO, A.; CRICKMORE, N. 2001. How Bacillus thuringiensis hás envolved specific toxins to colonize the insect world. Trends in Genetics, v. 17, n. 4, p. 193199. 
ESTRUCH, J. J.; WARREN, G. W.; MULLINS, M. A.; NYE, G. J.; GRAIG, J. A.; KOZIEL, M. G. 1996. VIP3A, A novel Bacillus thuringiensis vegetative insecticidal protein with a wide spectrum of activities against lepidopteran insects. Proceedings of the National Academics of Sciences. v. 93, p. 5389-5394.

FARKAS, J.; SEBESTA, K.; HORSKA, K.; SAMEK, Z.; DOLEJS, S.; SORM, F. 1977. The structure of exotoxins of Bacillus thuringiensis. Collection of Czechoslovak Chemical Communications. v. 42, p. 909-929.

FASORANTI, J. O.; GARA, R. I.; GEISZLER, D. R. 1982. Laboratory studies on the flight capacity of the mahogany shoot borer, Hypsipyla grandella (Zeller) (Lepidoptera, Pyralidae). Zeitschrift fur Angewandte Entomologie, v. 93, p. 182-186.

FAUST, R. M.; BULLA JR, A. L. 1982. Bacterial and their toxins as insecticides. In: KURSTAKI, E., Microbial and viral pesticides. New york: Marcel Dekker, p. 75-206.

FELFILI, J. M.; MAZZEI, L. 2001. Desenvolvimento do mogno (Swietenia macrophylla King) sob diferentes tratamentos silviculturais no Cerrado do Distrito Federal. Brasília Universidade de Brasília, Departamento de Engenharia Florestal, Comunicações Técnicas Florestais, v. 3, n. 3, 49 p.

FUNATURA (Fundação Pró-Natureza). 1993. Projeto Mogno: Sumário Executivo. Brasília, DF. $221 \mathrm{p}$. 
GASPAROTTO, L; BENTES J. L. S; PEREIRA, J. C. R. 2014. Doenças de espécies florestais arbóreas nativas e exóticas na Amazônia. Embrapa, Brasília, DF. 209 p.

GOETTEL, M. S.; INGLIS, G. D. 1997. Fungi: Hyphomycetes. In: LACEY, L. (Ed.). Manual of techniques in insect pathology. New York: Academic Press, p. 213-249.

GRIFFITHS, M. W. 2000. The biology and host relations of the red cedar tip moth, Hypsipyla robusta, in Australia. In: SNELL, A.; VIZE, S. (Ed.) Opportunities for the New Millennium: Proceedings of the Australian Forest Growers Biennal Conference. Canberra: Australian Forest Growers, p. 135-140.

GRIFFITHS, M. W. 2001. The biology and ecology of Hypsipyla shoot borers. In: FLOYD, R. B.; HAUXWELL, C. (Ed.) Hypsipyla Shoot Borers in Meliaceae: Proceedings of an International Workshop. Canberra: Australian Centre for International Agricultural Research, p. 74-80.

GRIJPMA, P. 1971. Studies on the shootborer Hypsipyla grandella Zeller. Observations on a rearing technique and on host selection behavior of adults in captivity. Turrialba, v. 21, p. 202-213.

GRIJPMA, P. 1974. Contributions to an integrated control program of Hypsipyla grandella (Zeller) in Costa Rica. Doctoral Thesis. State Agriculture University of Wageningen, Holland. 
GRIJPMA, P. 1976. Resistance of Meliaceae against the shoot borer Hypsipyla with particular reference to Toona ciliata M. J. Roem. var. australis (F.v. Muell.) CDC. In: BURLEY, J.; STYLES, B.T., ed. Tropical trees: variation breeding and conservation. London, Linnaean Society, p. 69-78.

GRIJPMA, P.; GARA, R. I. 1970. Studies on the shootborer Hypsipyla grandella (Zeller): II. Host preference of the larva. Turrialba, v. 20, p. 241-247.

GRIJPMA, P.; ROBERTS, S. C. 1976. Biological and chemical ascreening for the basis of resistance of Toona ciliate M. J. Roem. var australis. In: WHITMORE, J. L (Ed.) Studies on the shootborer Hypsipyla grandella (Zeller) Lep. Pyralidae. Vol. III. San José: Centro Agronómico Tropical de Investigación y Enseñanza, p. 103-109.

Grogan, J.; BARRetO, P.; VERÍSSIMO, A. 2002. Mogno na Amazônia Brasileira: ecologia e perspectivas de manejo. Belém: Imazon, 56 p.

HABIB, M. E. M.; ANDRADE, C. F. S. 1998. Bactérias entomopatogênicas. In: Controle microbiano de insetos. Ed. ALVES, S.B., FEALQ, Piracicaba, p. 383-446.

HADI, S.; NUHAMARA, S. T.; SANTOSO, E.; NAIR, K. S. S.; SHARMA, J. K.; VARMA, R. V. (Ed). 1993. Impact of diseases and insect pests in tropical forests. In: IUFRO SYMPOSIUM, 1993, Peechi, India. Proceedings... Peechi: IUFRO, p. 105-110. 
HANSEN, B.M.; SALAMITOU, S. 2000. Virulence of Bacillus thuringiensis. In: CHARLES et al. Entomopathogenic Bacteria: From Laboratory to Field Application. Kluwer Academic Publishers, p. 41-64.

HAUXWELL, C.; FLOYD, R. B. 2001. Hypsipyla Shoot Borers in Meliaceae. Australina Centre for International Agricultural Research, Canberra. 176 p.

HIDALGO-SALVATIERRA, O.; PALM, J. D. 1973. Susceptibility of first instar larvae to Bacillus thuringiensis. In: GRIJPMA, P. (Ed). Studies on the shoot borer Hypsipyla grandella (Zeller) Lep. Pyralidae. Vol. I, p. 88.

HU, G.; ST. LEGER, R. J. 2002. Field studies using a recombinant mucoinsecticide (Metarhizium anisopliae) reveal that it is rhizosphere competent. Applied and Environmental Microbiology, Washington, v. 68, n. 12, p. 6383-6387.

HUMBER, R. A. 1997. Fungi: identification. In: LACEY, L. (Ed.) Manual of techniques in insect pathology. New York: Academic Press, p. 153-185.

IVIE, M. A.; POLLOCK, D. A.; GUSTAFSON, D. L.; IVIE, L. L.; RASOLOMANDIMBY, J.; SWEARINGEN, W. D. 2002. Field-based evaluation of biopesticide impacts on native biodiversity: Malagasy coleopteran and anti-locust entomopathogenic fungi. Journal of Economic Entomology, College Park, v. 95, p. 651-660. 
JACINTO, J. M. de M. Análise silvicultural urbana de seis espécies florestais utilizadas na arborização de Brasília. (Dissertação de Mestrado em Ciências Florestais). Brasília, DF, 2001. 65 p.

KAMATH, M. K.; SENIVASA, E.; BOLA, I. 1993. Impact of térmites on mahogany (Swietenia macrophylla King) plantations in Fiji. IUFRO Seminar Proceedings, Kerala Forest Research Institute, Peechi, Kerala, India, 9 p.

KAMATH, M. K.; SENIVASA, E.; RARAVULA, T. G. 1995. Termite damage in forest trees in Fiji. Fiji Agri, v. 51, n. 1, p. 9-19.

KAMATH, M. K.; SENIVASA, E.; BOLA, I. 1996. Impact of termites on mahogany (Swietenia macrophylla) plantations in Fiji, In: Impact of Diseases and Insect Pests in Tropical Forests, ed. K. S. S. Nair, J. K. Sharma and R. V. Varma. Peechi, India: Kerala Forest Research Institute, p. 298-303.

KANDASAMY, D. 1969. Hypsipyla robusta Moore, a new host for Beauveria tenella (Delacroix) Siemaszko. Journal of Invertebrate Pathology, v. 13, p. 149-150.

KNOWLES, B. H.; ELLAR, D. J. 1987. Colloid-osmotic lysis a general feature of mechanism of action of Bacillus thuringiensis delta-endotoxins with different insect specificity. Biochimica et Biophysica Acta, v. 924, p. 509-518.

KIM, Y.T.; HUANG, P. 1970. The beta-exotoxin of Bacillus thuringiensis. I. Isolation. Journal of Invertebrate Pathology, v. 15, p. 100-108. 
KRIEG, A. 1971. Is The Potential Pathologicity Of Bacilli For Insects Related To Production Of Alpha-Exotoxin. Journal of Invertebrate Pathology, v. 18, p. 425-426.

KRYWUNCZYK, J.; FAST, P. G. 1980. Sorological relationships of the crystals of Bacillus thuringiensis var. israelensis. Journal of Invertebrate Pathology, v. 36, p. 139-140.

KURIHARA, D. L.; IMAÑA-ENCINAS, J. 2003. A arborização do campus da Universidade de Brasília. Revista Científica Eletrônica de Engenharia Florestal. Agosto de 2003. Ano I, n. 2 .

LAMB, F. B. 1966. Mahogany of Tropical America: its Ecology and Management. University of Michigan, Ann Arbor, MI, USA. 220 p.

LARREA, D. M. 1999. Effect of growth stage, and nitrogen and carbon concentration, on Swietenia macrophylla (Meliaceae) seedling folivory by insects. Ecologia en Bolivia, v. 32, p. 29-35.

LECHNER, M.; KUPKE, T.; STEFANOVIC, S.; GÖTZ, F. 1989. Molecular characterization and sequence of phosphatidylinositol-specific phospholipase $\mathrm{C}$ of Bacillus thuringiensis. Molecular Microbiology, Oxford, v. 3, p. 621-626.

LIANG, Y.; PATEL, S. S.; DEAN, D. H. 1995. Irreversible binding kinetics of Bacillus thuringiensis CryIA - endoxins to gypsy moth brush border membrane vesicles is directly correlated to toxicity. Journal of Biological Chemistry v. 270, p 24719-24724. 
LIMA, R. M. C. 2009. Avaliaçã da arborização urbana do Plano Piloto. Dissertação (Mestrado em Ciências Florestais), Publicação PPGEFL.DM - 117/2009, Departamento de Engenharia Florestal, Universidade de Brasília, Brasília, DF, 84 p.

LORENZI, H. 1992. Árvores Brasileiras: manual de identificação e cultivo de plantas arbóreas nativas do Brasil. São Paulo, p. 231-235.

LUNZ, A. M; THOMAZINI, M. J.; MORAES, M. C. B.; NEVES, E. J. M.; BATISTA, T. F. C.; DEGENHARDT, J.; SOUSA, L. A.; OHASHI, O. S. 2009. Hypsipyla grandella em Mogno (Swietenia macrophylla): situação atual e perspectivas. Pesquisa Florestal Brasileira, n. 59, p. 45-55.

MACHADO, J. W. B.; ALENCAR, F. O. C. C.; RODRIGUES, M. G. R. 1992. Árvores de Brasília. GDF, Brasília.

MAHROOF, R. M.; HAUXWELL, C.; EDIRISINGHE, J. P.; WATT, A. D.; NEWTON, A. C. 2002. Effects of artificial shade on attack by the mahogany shoot borer, Hypsipyla robusta (Moore). Agricultural and Forest Entomology, Midlothian, n. 4, p. 283-292.

MAYHEW, J. E.; NEWTON, A. C. 1998. The Silviculture of Mahogany. Wallingord, Oxon: CAB International.

MElO, J. E.; CARVAlHO, G. M.; MARTINS, V. A. 1989. Espécies de Madeiras Substitutas do Mogno. IBAMA/LPF, Série Técnica, n. 6, 16 p. 
MENDES, M. A. S.; SILVA, V. L.; DIANESE, J. C.; FERREIRA, M. A. S. V.; SANTOS, C. E. N.; GOMES NETO, E.; URBEN, A. F.; CASTRO, C. 1998. Fungos em plantas no Brasil. Brasília, DF: Embrapa-SPI: Embrapa-Cenargen, 569 p.

MISRA, R. M. 1993. Beauveria bassiana (Balsamo) Vuillemin, a fungal pathogen of Hypsipyla robusta Moore (Lepidoptera: Pyralidae). Indian Journal of Forestry, v. 16, p. 236-238.

MOHANADAS, K. 2000. Management of the shoot borer Hyspsipyla robusta (Lepidoptera: Phycitidae) in mahogany plantations. KFRI Research Report n. 184. Peechi, India: Kereala Forest Research Institute.

MONNERAT, R. G.; BRAVO, A. 2000. Proteínas bioinseticidas produzidas pela bactéria Bacillus thuringiensis: modo de ação e resistência. In: Controle Biológico, eds. Melo, I.S. e Azevedo, J.L, Jaguariúna, SP, Embrapa Meio Ambiente, v. 3, p.163-200.

MONNERAT, R. G.; PRAÇA, L. 2006. Bacillus thuringiensis e Bacillus sphaericus. In: OLIVEIRA-FILHO, E. C.; MONNERAT, R. G. (Ed.). Fundamentos para a regulação de semioquímicos, inimigos naturais e agentes microbiológicos de controle de pragas. Planaltina, DF: Embrapa Cerrados, p. 121-155.

MYERS, J. G. 1935. Second report on an investigation into the biological control of West Indian insect pests. Bulletin of Entomological Research, v. 26, p. 181-252. 
NAIR, K. S. S. 2007. Tropical Forest Insect Pests: Ecology, Impact, and Management. Division of Entomology and Director, Kerala Forest Research Institute. Cambridge University Press, 424 p.

NICKLE, W. R.; GRIJPMA, P. 1974. Hexamermis albicans (Siebold) (Nematoda: Mermithidae), a parasite of the larva. In: WHITMORE, J. L. (Ed.). Studies on the shoot borer Hypsipyla grandella (Zeller) Lep. Pyralidae, Vol. II, p. 70-74.

OHASHI, O. S.; COSTA, M. S. S.; SILVA, J. N. M.; SILVA, M. F. G. G. 2000. Resistência do tipo antibiose apresentada pelas folhas novas de Toona ciliata M. J. Roem às lagartas de Hypsipyla grandella Zeller. Comunicado Técnico, 48. Belém: Embrapa Amazônia Oriental. $3 \mathrm{p}$.

OHASHI, S. T.; SILVA, J. N. M.; SILVA, M. E. C. E.; COSTA, M. S. S.; SARMENTO JUNIOR, R. G.; SANTOS, E. B.; ALVES, M. Z. N.; PESSOA, A. M. C.; SILVA, T. C. O.; BITTENCOURT, P. R. G.; BARBOSA, T. C.; SANTOS, T. M. 2002. Manejo Integrado da Broca do Mogno Hypsipyla grandella Zeller (Lep. Pyralidae). In: POLTRONIERI, L. S.; TRINDADE, D. R. Manejo integrado das principais pragas e doenças de cultivos amazônicos. Belém: Embrapa Amazônia Oriental, 304 p.

OLIVER, W. W. 1992. Plantation forestry in the South Pacific: A compilation and assessment of practices. Field Document 8, USDA Forest Service, Pacific Southwest Research Station, Redding, California. 
PAIS, M.; DE BARJAC, H. 1974. Termostable exotoxin of Bacillus thuringiensis. Journal Carbohydrates, Nucleosides and Nucleotides. v. 1, p. 213-223.

PANDEY, D. 1983. Growth and yield of plantation species in the tropics. Rome, Italy: FAO (W/R 0867).

PANDEY, D. 1997. Hardwood plantations in the tropics and subtropics: Tropical forest plantation areas 1995, Project GCP/INT/628/UK. Rome: FAO.

PENNington, T. D. \& SARUKHÁN, J. 1968. Árboles Tropicales de Mexico. INIF / FAO, Mexico, 413 p.

PINHEIRO, A. L. 2000. Resistência do mogno (Swietenia macrophylla King) à Hypsipyla grandella Zeller. Folha Florestal. Informativo Técnico do Departamento de Engenharia Florestal da UFV Universidade Federal de Viçosa, n. 97.

PRAÇA, L. B.; SOARES, E. M.; VELATTI, V. M.; MONNERAT, R. G. 2007. Bacillus Thuringiensis Berliner (Eubacteriales: Bacillaceae): aspectos gerais, modo de ação e utilização. Boletim Técnico n. 239. Brasília, DF: Embrapa Recursos Genéticos e Biotecnologia, $40 \mathrm{p}$.

PRANCE, G. T.; SILVA, M. F. 1975. Árvores de Manaus. Manaus: INPA. 312 p. 
QUESADA-MORAGA, E.; GARCIA-TÓVAR, E.; VALVERDE-GARCIA, P.; SANTIAGOALVAREZ, C. 2004. Isolation, geographical diversity and insecticidal activity of Bacillus thuringiensis from soils in Spain. Microbiological Research, v. 159, n. 1, p. 59-71.

RAO, V. P. 1969. US PL-480 project: survey for natural enemies Hypsipyla robusta Moore in India. Final technical report for the period July 25, 1964 to July 24, 1969. Commonwealth Institute for Biological Control, Trinidad.

RAO, V. P.; BENNET, F. D. 1969. Possibilities of biological control of the Meliaceous shoot borers, Hypsipyla spp. (Lepidoptera: Phycitidae). Technical Bulletin Commonwealth Institute for Biological Control, v. 12, p. 61-81.

RIZZINI, C. T. 1990. Árvores e madeiras úteis do Brasil - Manual de dendrologia brasileira. $2^{\circ}$ ed. São Paulo: Editora Edgard Blucher, 286 p.

ROBERTS, H. 1965. A survey of the important shoot, stem, wood, flower and fruit boring insects of the Meliaceae in Nigeria. Nigerian Forestry Information Bulletin, v. 15, p. 15-25.

ROBERTS, H. 1977. When ambrosia beetles attack mahogany trees in Fiji. Unasylva, v. 29, n. 117 , p. $25-28$.

SAMISH, M.; GLAZER, J. 1991. Killing ticks with parasitic nematodes of insects. Jounal Inverted Pathology, v. 58, p. 281-282. 
SARMENTO JUNIOR, R. G. 2001. Biologia de Hypsipyla grandella (Zeller, 1848) e avaliação da resistência de Swietenia macrophylla King, Cedrela odorata L., Toona ciliata Roem e Toona sp. à broca das meliáceas em laboratório. Dissertação (Mestrado em Agronomia), Instituto de Ciências Agrárias, Faculdade de Ciências Agrárias do Pará, 60 f.

SEBESTA, K.; HORSKA, K. 1968. Inhibition on DNA-dependent RNA polymerse by exotoxin of Bacillus thuringiensis var. galechiae. Biochemica et Biophysica Acta, v. 169, p. 281-282.

SILVA, N. M. 1985. Características biológicas e demográficas de Hypsipyla grandella (Zeller, 1848) (Pyralidae, Lepidoptera) e níveis de infestação sob dois sistemas de plantio de Carapa guianensis Aubl. (Meliaceae) no Amazonas. Dissertação (Mestrado em Ciências Biológicas), Departamento de Ciências Fundamentais e Desenvolvimento Agrícola, Instituto Nacional de Pesquisas da Amazônia, 103 f.

SILVA, T. C. O. 2003. Dieta artificial para a criação de Hypsipyla grandella (Zeller, 1848) (Lepidoptera), broca das meliáceas, em laboratório. Dissertação (Mestrado em Agronomia), Instituto de Ciências Agrárias, Universidade Federal Rural da Amazônia, 73 f.

SOBERÓN, M.; BRAVO, A. 2001. Bacillus thuringiensis y sus toxinas insecticidas. Disponível em: <http://biblioweb.dgsca.unam.mx/libros/microbios/Cap12/>. Acesso em: 03 nov. 2015.

STEVEnSON, N. S. 1940. Report of the Forest Department for the year 1939. The Government Printer, British Honduras. 
SUHARTI, M.; IRIANTO, R. S. B. 1992.Virulence trial for four species of fungus that cause leaf spot disease on Eucalyptus urophylla and Swietenia macrophylla. Buletin Penelitian Hutan, Bogor, n. 553, p. 33-48.

TAVERAS, R.; HILJE, L. CARBALLO, M. 2004. Development of Hypsipyla grandella (Zeller) (Lepidoptera: Pyralidae) in response to constant temperatures. Neotropical Entomology, n. 33, p. 1-6.

TIGANO, M. S.; MELLO, S. C. M. 2006. Fungos Agentes de Controle Biológico. In: OLIVEIRA-FILHO, E. C.; MONNERAT, R. G. (Ed.) Fundamentos para a Regulação de Semioquímicos, Inimigos Naturais e Agentes de Microbiológicos de Controle de Pragas. Embrapa Cerrados, Planaltina, p. 157-174.

TOUMANOFF, C. 1952. A propos d'un bacille patogene pour les vers a soie au Japan Bacillus sotto (Ishiwatta) et ses affinites avec d'auttes bacilles entomophytes de Bacillus cereus Fr. \& Fr. Avec remarues sur le jaune d'oeuf. Annales de I'Institute Pasteur, v. 85, p. 90-99.

TRINDADE, A. S.; COElHO NETTO, R. A.; ASSIS, L. A. G.; BARBOSA, A. P. Ocorrência de antracnose em folhas de mogno no Amazonas. 2004. Fitopatologia Brasileira, Brasília, DF, v. 28, p. 299-300.

VALADARES-INGLIS, M.C.C.; SHILER, W.; DE-SOUZA, M.T. 1998. Engenharia genética de microrganismos agentes de controle biológico. In: Controle Biológico VOL.1. ED.: 
MELO, I.S; AZEVEDO, J.L, JAGUARIÚNA, SP, EMBRAPA MEIO AMBIENTE,: p. 201230.

VAN RIE, J.; JANSENS, S.; HÖFTE, H.; DEGHEELE, D.; VAN MELLAERT, H.. 1989. Specificity of Bacillus thuringiensis -endotoxin: importance of specific receptors on the brush border membrane of the mid-gut of target insects. European Journal of Biochemistry, v. 186, p. 239-247.

VARGAS, C; SHANNON, P. J.; TAVERAS, R.; SOTO, F.; HILJE, L. 2001. Un Nuevo método para la cría massiva de Hypsipila grandella. Manejo Integrado de Plagas, n. 62, p. $1-4$.

WANG, C.; FAN, M.; LI, Z.; BUTT, T. M. 2004. Molecular monitoring and evaluation o the application of the insect-pathogenic fungos Beauveria bassiana in southeast China. Journal of Applied Microbiology, Danvers, v. 96, p. 861-870.

WHITELEY, H. R.; SCHNEPF, H. E. 1986. The molecular biology of parasporal crystal body formation in Bacillus thuringiensis. Annual Review of Microbiology, v. 40, p. 549576.

WILLIAMS, L. 1932. Peruvian mahogany. Tropical Woods, v. 31, p. 30-37.

WOLFERSBERG, M. G. 1992. V-ATPase-energized epithelia and biological insect control. Journal of Experimental Biology, v. 172, p. 377-386. 
WYLIE, F. R. 2001. Control of Hypsipyla spp. shoot borers with chemical pesticides: a review. In: FLOYD, R. B.; HAUXWELL, C. (Ed.) Hypsipyla Shoot Borers in Meliaceae: Proceedings of an International Workshop. Canberra: Australian Centre for International Agricultural Research, p.109-117.

YAMAZAKI, S.; TAKETANI, A.; FUJITA, K. VASQUES, C.; IKEDA, T. 1990. Ecology of Hypsipyla grandella and its seasonal changes in population density in Peruvian Amazon forest. Japan Agricultural Quarterly, n. 24, p. 149-155.

YARED, J. A. G.; CARPANEZZI, A. A. 1981. Conversão de capoeira alta da Amazônia em povoamento de produção madeireira: o método "recrû" e espécies promissoras. Belém: EMBRAPA CPATU, 27 p.

YU, C-G.; MULLINS, M.A.; WARREN, G.W.; KOZIEL, M.G.; ESTRUCH, J.J. 1997. The Bacillus thuringiensis vegetative insecticidal protein VIP3A lyses midgut epithelium cells of susceptible insects. Applied and Environmental Microbiology, v. 63, p. 532-536. 


\section{CAPÍTULO 1}

\section{DANOS EM FRUTOS DE MOGNO (Swietenia macrophylla King) CAUSADOS POR Hypsipyla grandella Zeller (Lepidoptera: Pyralidae) EM BRASÍLIA, DISTRITO FEDERAL}

\subsection{RESUMO}

Estudos a respeito do dano causado por insetos em frutos do mogno são praticamente inexistentes. A partir disso, este estudo teve como objetivo relatar a ocorrência de Hypsipyla grandella em Brasília, Brasil, e avaliar qualitativamente e quantitativamente os danos provocados pelo inseto em frutos de mogno. Para isso, frutos foram coletados e os seguintes parâmetros foram analisados: peso, comprimento, número de orifícios causados pela $H$. grandella, número de sementes danificadas e presença de outros insetos no interior dos frutos. Como resultado, 190 (95\%) frutos apresentaram orifícios feitos pela lagarta, usados primordialmente para sua entrada e posteriormente para a saída, quando adulto. A maioria dos frutos apresentou apenas um orifício (81\%), mas até cinco furos foram encontrados em um único fruto. Uma única lagarta pode se alimentar de várias sementes, causando grandes danos. Setenta e dois frutos (36\%) tinham todas as sementes danificadas pela $H$. grandella, especialmente aqueles que apresentaram pupas. 183 lagartas em diferentes instares e 45 pupas foram encontradas. Até oito lagartas de diferentes instares foram encontradas em um único fruto, o que indica que o inseto não possui hábitos canibais. Apenas cinco lagartas foram encontradas mortas dentro dos frutos, representando $2,78 \%$ do total de lagartas.

Palavras-chave: praga florestal, entomologia florestal, broca do mogno. 


\section{DAMAGES IN FRUITS OF MAHOGANY (Swietenia macrophylla King) CAUSED BY Hypsipyla grandella Zeller (Lepidoptera: Pyralidae) IN BRASÍLIA, BRAZIL}

\subsection{ABSTRACT}

Studies relating the damage caused by insects in mahogany fruits are practically nonexistent. Therefore, this study aimed to report the occurrence of Hypsipyla grandella in Brasilia, Brazil, and evaluate qualitatively and quantitatively the insect damage in fruits of mahogany. For this, fruits were collected and the analysis of each fruit was carried out by assessing the following parameters: fruit weight, fruit length and height, number of holes in fruits characteristic of $H$. grandella attack, size of the holes, number of larvae and pupae of $H$. grandella, number of seeds damaged and presence of other insects within the fruit. As a result, $190(95 \%)$ had holes made by the larvae, used primarily for their entry and for exit later as an adult. Most of the fruits showed only a single hole (81\%), but up to 5 holes were found in a single fruit. A single caterpillar can feed on various seeds, causing major damage when they attack together. Seventy-two (36\%) fruits had all the seeds damaged by $H$. grandella, especially those containing pupae. 183 larvae in different instars and 45 pupae were found. Up to eight larvae of different sizes and instars were found in a single fruit, which may be an indication that this insect does not have cannibalistic habits. Only five caterpillars were found dead inside of fruit, representing $2.78 \%$ of the caterpillars.

Keywords: forest pest, forest entomology, shoot borer. 


\subsection{INTRODUÇÃO}

O gênero Hypsipyla, pertencente à família Pyralidae, possui duas espécies de ocorrência no Brasil, a Hypsipyla ferrealis Hampson, que ataca sementes de plantas do gênero Carapa Aubl., e a Hypsipyla grandella Zeller, que ataca várias espécies da família Meliaceae, incluindo o mogno brasileiro, Swietenia macrophylla King. O sintoma do ataque do inseto na árvore pode ser observado pela exsudação de goma e serragem nos brotos, e nos frutos destroem as sementes (Lima, 1940).

O fruto do mogno fica suspenso na árvore e é do tipo baga ovulada, envolto por uma cápsula lenhosa (Cordeiro, 2012). Os frutos contêm um número variado de sementes, podendo chegar até 70 (Snook, 1998). Suas sementes são aladas, com 6 a $13 \mathrm{~cm}$ de comprimento por 1 a $2,5 \mathrm{~cm}$ de largura (Cordeiro, 2012) e são dispersas pelo vento (Pennington et al., 1981). Uma árvore adulta de mogno pode produzir até 600 frutos ou 30.000 sementes por ano (Gullison et al., 1996).

Várias espécies de lepidópteros das famílias Crambidae, Tortricidae e Pyralidae predam os frutos e sementes de um amplo número de espécies de plantas (Janzen, 1971). Segundo Zhang et al. (1997), a predação de sementes é considerada um fator predominante na morte das sementes, podendo reduzir a oferta ou impedir a germinação, tendo consequências na riqueza, diversidade e distribuição das plantas. Janzen (1971) observa que os insetos como agentes bióticos têm impacto importante na fase de pré-queda, no qual a predação de um elevado número de sementes pode causar efeitos importantes na regeneração, reduzindo as taxas de recrutamento e limitando a colonização.

A ocorrência de orifícios em frutos e sementes é referida por Vanin \& Gaiger (2005) como um sinal de relevante importância na avaliação da ocorrência de predação. Os orifícios podem indicar o ponto de postura de ovos ou de exclusão de metabólitos do inseto durante o 
seu desenvolvimento no interior do fruto/sementes ou ainda o local de emergência do inseto adulto.

Estudos no Brasil referentes aos danos em frutos de mogno por insetos são praticamente inexistentes. Portanto, este trabalho teve como objetivo avaliar qualitativamente e quantitativamente os danos causados por $H$. grandella em frutos de mogno em Brasília, Distrito Federal.

\subsection{MATERIAL E MÉTODOS}

\subsubsection{Obtenção dos frutos de mogno}

Os frutos foram coletados em Brasília/DF, no período de fevereiro a maio de 2013. As árvores podem ser encontradas em diversos pontos da cidade (Tabela 1).

Tabela 1: Locais de coleta de frutos de mogno em Brasília/DF.

\begin{tabular}{cccc}
\hline Local & Coordenadas & Número de árvores & Altura $(\mathrm{m})$ \\
\hline SQN 115 & $15.741325 \mathrm{~S} / 47.894049 \mathrm{~W}$ & 14 & $10-15$ \\
SQN 116 & $15.738109 \mathrm{~S} / 47.892704 \mathrm{~W}$ & 28 & $10-15$ \\
SQN 315 & $15.742704 \mathrm{~S} / 47.894265 \mathrm{~W}$ & 74 & $10-20$ \\
SQN 316 & $15.737453 \mathrm{~S} / 47.895735 \mathrm{~W}$ & 108 & $5-20$ \\
CENARGEN & $15.729769 \mathrm{~S} / 47.902214 \mathrm{~W}$ & 8 & $10-12$ \\
\hline
\end{tabular}

Segundo a classificação de Koppen, o clima da região é classificado como AW (clima tropical com chuvas no verão e seca no inverno), com a estação chuvosa de outubro a abril e a seca de maio a setembro. A temperatura média anual é de $21^{\circ} \mathrm{C}$ e umidade relativa do ar é de aproximadamente $70 \%$ (Weatherbase, 2013).

Foram coletados aleatoriamente 200 frutos caídos no chão, com ou sem sintomas característicos do ataque de $H$. grandella. Todos os frutos obtidos eram imaturos, com sementes verdes e de tamanhos variados. 


\subsubsection{Análise dos danos nos frutos coletados}

O material coletado foi levado para o Laboratório de Bactérias Entomopatogênicas da Embrapa Recursos Genéticos e Biotecnologia e foi feita a análise de cada fruto avaliando-se as seguintes características:

1. Peso dos frutos (g), com o uso de uma balança digital;

2. Tamanho do fruto $(\mathrm{cm})$, com o auxílio de uma régua milimétrica;

3. Contagem do número de orifícios em frutos característicos do ataque de $H$. grandella;

4. Diâmetro dos orifícios $(\mathrm{cm})$, com o auxílio de uma régua milimétrica;

5. Número de lagartas de H. grandella encontradas;

6. Numero de pupas de H. grandella encontradas;

7. Número de sementes danificadas pela $H$. grandella;

8. Presença de outros insetos no interior do fruto.

Apenas as lagartas a partir do $3^{\circ}$ instar entraram na contabilização total, por apresentarem características típicas de $H$. grandella e serem passíveis de identificação com maior acurácia. As sementes que apresentam qualquer tipo de dano, mesmo que apenas na ala, também foram contabilizadas. A presença de outros insetos não foi contabilizada, apenas relatada a sua ocorrência ou não.

Os dados obtidos foram avaliados em relação à correlação existente entre o número de lagartas e o peso e tamanho dos frutos e o número de sementes danificadas e a quantidade de lagartas e pupas em cada fruto. Foi aplicado o teste t aos níveis de $1 \%$ e 5\% de probabilidade, com o auxílio do programa Assistat 7.6 (Silva, 2013). 


\subsection{RESULTADOS E DISCUSSÃO}

Dos 200 frutos coletados, 190 (95\%) apresentaram orifícios feitos pelas lagartas, utilizados primordialmente para a sua entrada e posteriormente para a saída do adulto. Grande parte dos frutos apresentou apenas um único orifício $(81 \%)$ e foi encontrado até cinco orifícios em um único fruto (Figura 1). Muitas vezes foi possível observar excrementos, teia e goma próximos a esses orifícios, indicando a presença do inseto no interior dos frutos. Após a entrada da lagarta no fruto, as sementes são severamente danificadas, sobretudo o endosperma, resultando na perda da sua viabilidade. Uma única lagarta pode se alimentar de várias sementes, causando grandes danos quando estas atacam em conjunto. Além disso, a columela do fruto também foi danificada e muitas vezes o inseto se alojou em seu interior para empupar (Figura 2).

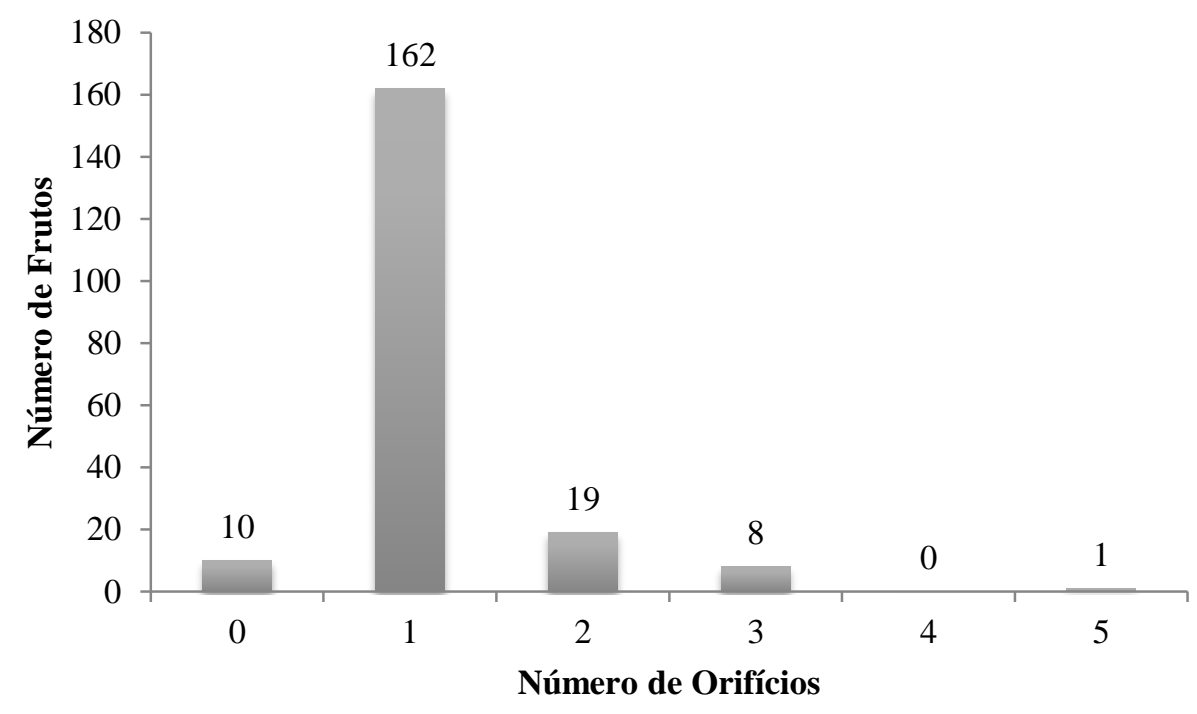

Figura 1. Número de orifícios feitos pela Hypsipyla grandella em frutos de mogno. 

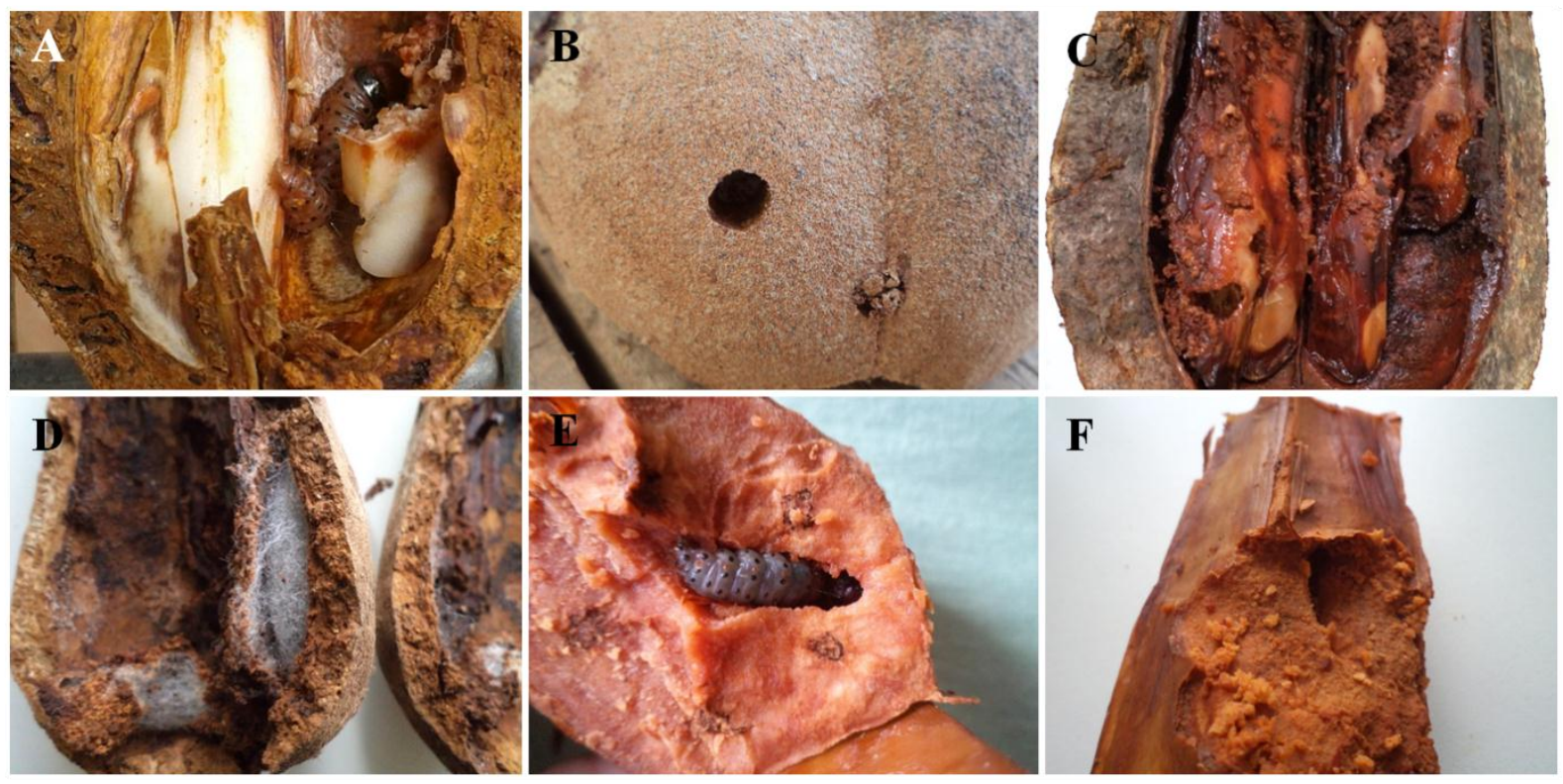

Figura 2 (A - F). Predação em frutos de mogno pela Hypsipyla grandella. A - Lagarta de $3^{\circ}$ instar no interior do fruto; B - Orifício feito pela lagarta; C - Sementes danificadas pelas lagartas; D - Pupas no interior do fruto; E - Lagarta de $6^{\circ}$ instar no interior da columela; F Columela danificada pela lagarta.

Os orifícios encontrados nos frutos de mogno feitos pela Hypsipyla grandella tinham em média 0,8 cm de diâmetro. Eles são feitos pelos insetos para diversos fins. Junqueira et al. (1996) observaram que a broca-da-semente da gravioleira, Bephratelloides pomorum (Fabricius) (Hymenoptera: Eurytomidae), faz um orifício na semente e percorre o caminho de saída até a casca do fruto, onde faz um orifício circular de $2 \mathrm{~mm}$ para sair. O maior dano causado por esse inseto consiste na queda dos frutos jovens, quando perfurados, e pelo fato dos orifícios servirem de porta de entrada para outras pragas e microrganismos causadores da podridão-dos-frutos (Braga Sobrinho et al., 1998; Gazel Filho et al., 2002; Gazel Filho \& Silva, 2003). No presente estudo, 95\% dos frutos analisados estavam predados. Em uma análise de frutos de Syagrus coronata (Martius) Beccari coletados em Caetés, foi constatado que em frutos com orifícios de saída e/ou pela presença da larva de Pachymerus nucleorum (Fabricius) (Coleoptera: Bruchidae) no processo de liberação da amêndoa, o nível de 
infestação alcançou $80 \%$ dos frutos analisados. Resultados semelhantes foram encontrados por Garcia et al. (1980) ao estudar a predação de frutos da espécie Syagrus oleracea (Martius) Beccari por P. nucleorum em vários municípios de Goiás, onde os autores encontraram uma variação na predação entre $42,03 \%$ e $84,5 \%$.

No total, foram encontradas 180 lagartas (Figura 3) em diferentes instares e 45 pupas. As lagartas menores e mais jovens foram encontradas geralmente no interior das sementes e as maiores e de últimos instares próximo ou dentro da columela do fruto. Até oito lagartas de diferentes tamanhos e instares foram encontradas em um único fruto, o que pode ser um indício que esse inseto não possui hábitos canibais. Três pupas foram encontradas em um único fruto (Figura 4), reforçando o fato de que provavelmente eles não sejam canibais.

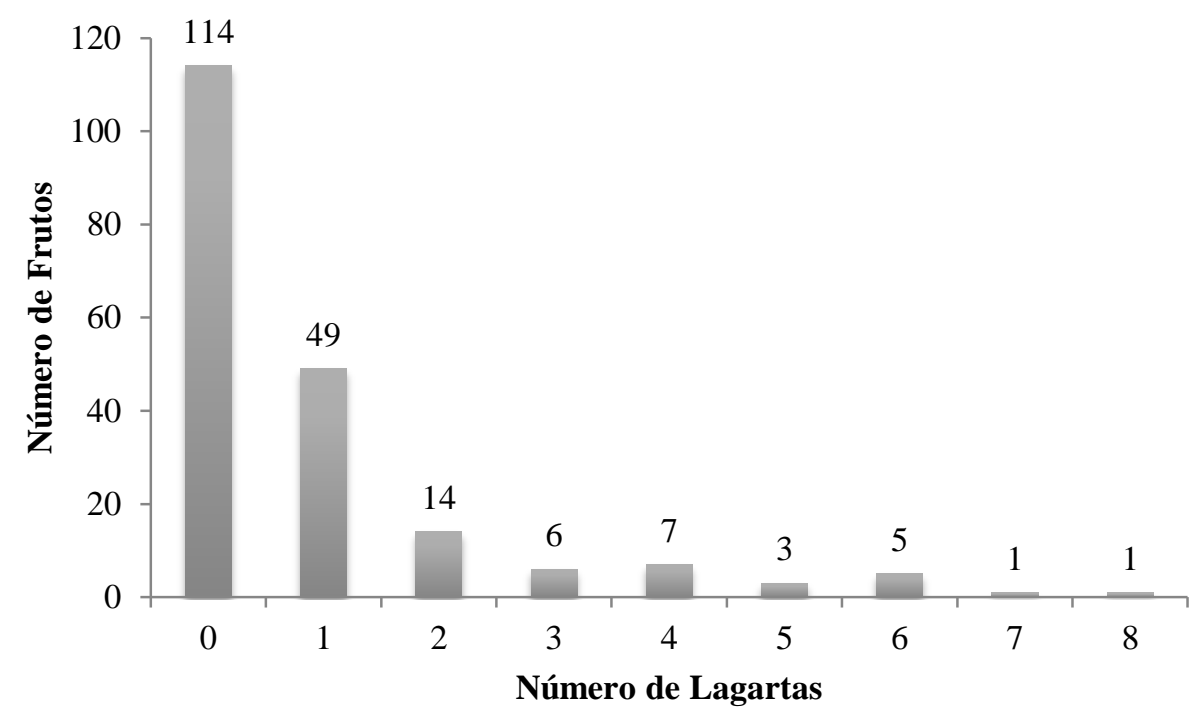

Figura 3. Número de lagartas de Hypsipyla grandella por fruto de mogno. 


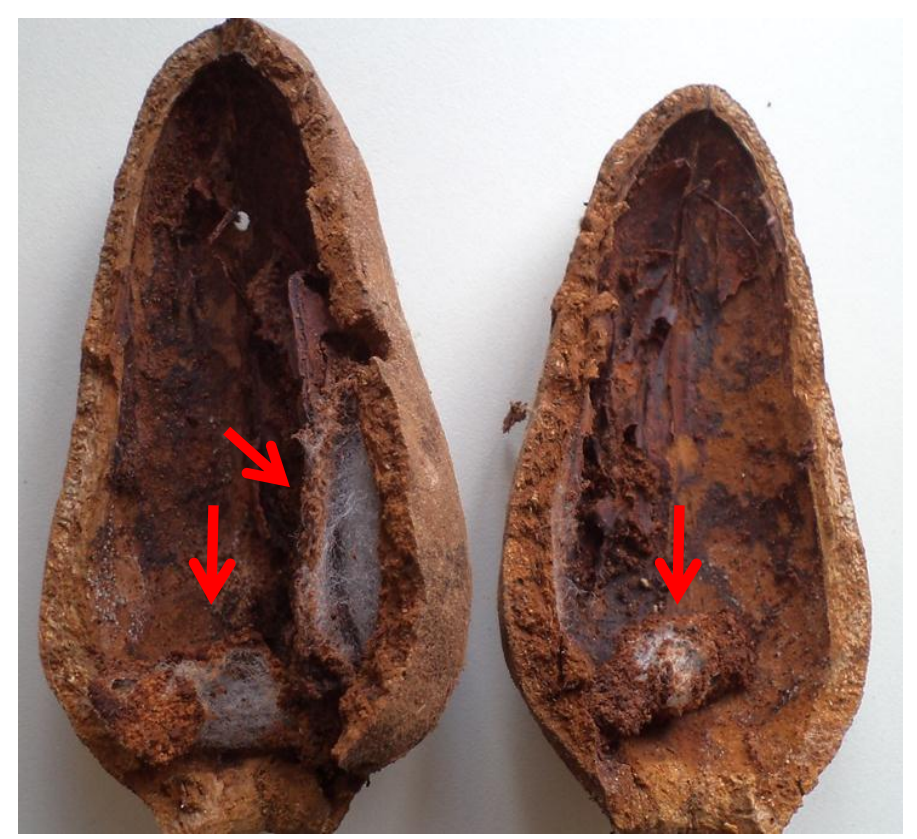

Figura 4. Pupas (setas) de Hypsipyla grandella no interior do fruto de mogno.

Apesar de possuírem orifícios, nem todos os frutos continham lagartas. Do total, 57\% dos frutos não possuíam indivíduos de $H$. grandella, apesar de apresentarem danos nas sementes e $24,5 \%$ continham apenas uma lagarta. Os frutos que apresentaram mais de duas lagartas totalizaram $18,5 \%$ (Figura 3 ).

Setenta e dois frutos, de um total de 200 , estavam com todas as sementes danificadas por $H$. grandella, sobretudo aqueles que continham pupas. Primeiramente, o endosperma da semente foi atacado, seguido pela ala e por último a columela. Após o ataque, com o endosperma totalmente comprometido, a semente fica inviável. Em um estudo realizado por Querino et al. (2008), ao analisar a predação de sementes de Carapa guianensis Aubl. por Hypsipyla ferrealis em São João da Balisa/RR, o endosperma sofreu intensidades diferenciadas de danos, desde danos mínimos, com sinais da lagarta pela presença de galerias, até totalmente destruídos, com resíduos de alimentação e/ou restos de casulos. Na Flórida, $H$. grandella atacou $100 \%$ das árvores de Swietenia mahogani (L.) Jacq. e consumiu entre $50 \%$ e $96 \%$ das sementes. Durante o mesmo período, somente $22 \%$ dos brotos novos foram atacados, 
inferindo na preferência da lagarta em se alimentar de sementes (Howard \& Giblin-Davis, 1997).

Insetos das ordens Coleoptera, Diptera, Isoptera e Dermaptera foram encontrados dentro dos frutos, juntos ou não com lagartas e pupas de H. grandella. Muitos insetos são provavelmente oportunistas, aproveitando-se dos orifícios de entrada da $H$. grandella e alimentando-se dos excrementos do inseto. Outros são possíveis predadores da lagarta, como alguns representantes de Dermaptera. Segundo Lemos (1997), os insetos dessa ordem são predadores vorazes, isto é, com alta capacidade de ataque e se alimentam de diversas presas, especialmente de ovos e formas imaturas das ordens Lepidoptera, Hemiptera, Coleoptera e Diptera. Não foram observados danos de outros insetos às sementes de mogno.

Apenas cinco lagartas foram encontradas mortas no interior dos frutos, representando $2,78 \%$ do total de lagartas encontradas $(n=180)$. Destas, três apresentaram sintomas de bacteriose, uma de fungo (vide capítulo 6) e outra por causas desconhecidas. A mortalidade foi inferior à verificada por Thomazini et al. (2011) quando coletaram lagartas no broto terminal de árvores de mogno, chegando a nove em um total de 28 coletadas no mês de maio de 2010 em Garça/SP. A mortalidade larval natural foi de 14,8\% em todo o estudo. Já em um trabalho realizado por Taveras et al. (2004), na Costa Rica, a taxa de mortalidade foi de $24 \%$. A baixa taxa de mortalidade dos insetos no presente estudo pode ser atribuída ao fato do inseto estar protegido de possíveis predadores e de contaminação por fungo e bactérias. $\mathrm{O}$ fato de o estudo ser realizado em árvores urbanas também pode influenciar a mortalidade, visto que na cidade há menor número de inimigos naturais quando comparada ao ambiente natural.

Não foram encontrados ovos sobre os frutos, pois estes são colocados preferencialmente nas brotações, ramos ou folhas (Grijpma \& Gara, 1970; Griffiths, 2001).

Dezoito pupários abandonados foram encontrados e um estava parasitado. Todas as pupas estavam próximas aos orifícios do fruto, provavelmente para facilitar a saída do adulto 
após a sua emergência. Do total de frutos, $81 \%$ não continham pupas, 16,5\% continham uma pupa, $1,5 \%$ duas pupas e $1 \%$ três pupas (Figura 5).

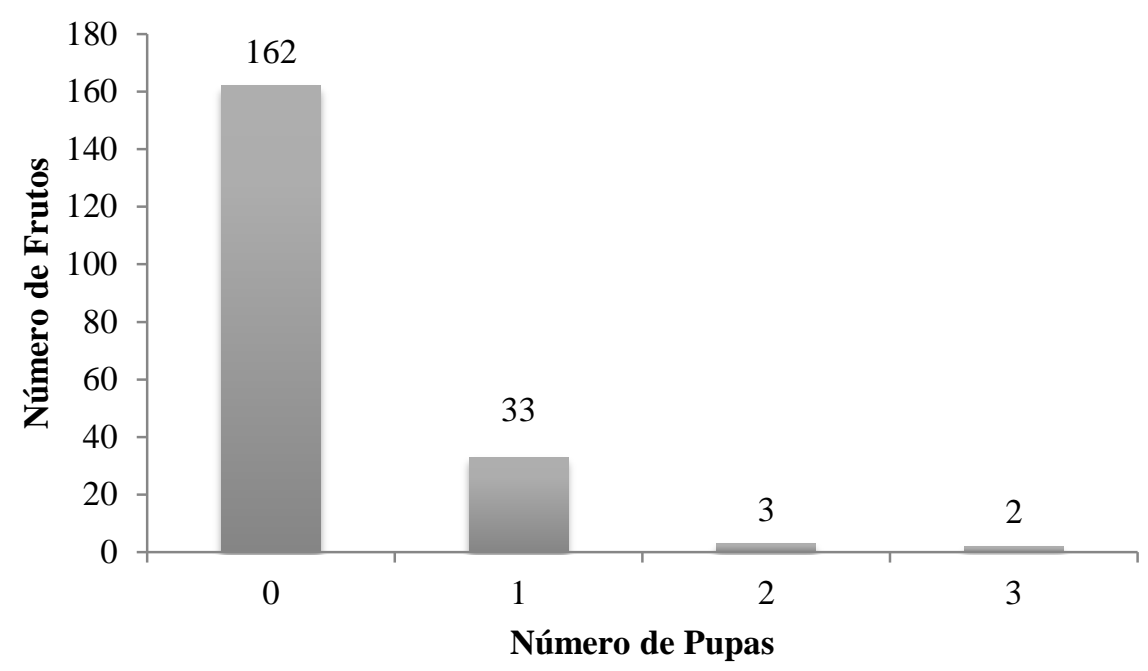

Figura 5. Número de pupas de Hypsipyla grandella por fruto de mogno.

A partir da Tabela 2 foi possível inferir que quanto maior o tamanho e o peso dos frutos, maior a quantidade de lagartas. O mesmo não ocorreu com o número de pupas, mas quanto mais orifícios os frutos possuírem, provavelmente será maior o número de pupários vazios ou não. 
Tabela 2. Matriz de correlação entre as variáveis analisadas.

\begin{tabular}{lccccc}
\hline Variável & $\begin{array}{c}\text { Tamanho } \\
\text { do Fruto }\end{array}$ & $\begin{array}{c}\text { Peso do } \\
\text { Fruto }\end{array}$ & $\begin{array}{c}\text { Número } \\
\text { de } \\
\text { Orifícios }\end{array}$ & $\begin{array}{c}\text { Número } \\
\text { de } \\
\text { Lagartas }\end{array}$ & $\begin{array}{c}\text { Número } \\
\text { de Pupas }\end{array}$ \\
\hline Tamanho do Fruto & 1 & 0,8440 & $-0,0386$ & 0,2797 & $-0,1829$ \\
Peso do Fruto & $* *$ & 1 & $-0,0432$ & 0,2974 & $-0,2217$ \\
Número de Orifícios & $* *$ & Ns & 1 & $-0,0040$ & 0,2517 \\
Número de Lagartas & $* *$ & $* *$ & Ns & 1 & $-0,0267$ \\
Número de Pupas & $* *$ & $* *$ & $* *$ & $\mathrm{~ns}$ & 1 \\
\hline
\end{tabular}

Em que: $*^{*}=$ significativo ao nível de $1 \%$ de probabilidade $(\mathrm{p}<0.01) ; *=$ significativo ao nível de $5 \%$ de probabilidade $(0.01=<\mathrm{p}<0.05)$; ns $=$ não significativo $(\mathrm{p}>=0.05)$.

O número de lagartas tem uma relação direta com o número de sementes danificadas, assim como o número de pupas, conforme a Tabela 3. Portanto, quanto maior o número de lagartas, provavelmente mais sementes serão danificadas. Em todos os frutos onde foram encontradas pupas em seu interior, todas as sementes estavam danificadas, o que indica que há um alto grau de predação das sementes por $H$. grandella.

Tabela 3. Matriz de correlação entre o número de lagartas e pupas de Hypsipyla grandella e o número de sementes de mogno danificadas.

\begin{tabular}{lccc}
\hline Variável & $\begin{array}{c}\text { Número } \\
\text { de } \\
\text { Lagartas }\end{array}$ & $\begin{array}{c}\text { Número } \\
\text { de } \\
\text { Pupas }\end{array}$ & $\begin{array}{c}\text { Número de } \\
\text { Sementes } \\
\text { Danificadas }\end{array}$ \\
\hline Número de Lagartas & 1 & $-0,0267$ & 0,2751 \\
Número de Pupas & ns & 1 & 0,3167 \\
Número de Sementes Danificadas & $* *$ & $* *$ & 1
\end{tabular}

Em que: $* *$ = significativo ao nível de $1 \%$ de probabilidade $(\mathrm{p}<0.01) ; *$ = significativo ao nível de $5 \%$ de probabilidade $(0.01=<\mathrm{p}<0.05)$; ns = não significativo ( $\mathrm{p}>=0.05)$. 
Resultados semelhantes foram obtidos por Pinto et al. (2013), onde perdas causadas pela predação de $H$. ferrealis e $H$. grandella em frutos de $C$. guianensis e Carapa procera D. C. na Reserva Florestal A. Ducke na Amazônia demonstraram que essas pragas são limitantes para essas culturas, destruindo frutos e sementes no campo.

Todos os frutos coletados estavam caídos, fato que pode ser explicado pela presença da $H$. grandella em seu interior. Roberts (1966, 1968) e Griffiths (1997) constaram a ocorrência de queda prematura de frutos do gênero Khaya na Nigéria e Toona ciliata M. Roem. na Austrália após o ataque do inseto. Na Austrália, as lagartas contornam o fruto com teia no ponto de abscisão, onde os frutos ficam pendurados na copa das árvores e o inseto desenvolve todo o seu ciclo dentro do fruto suspenso. Não foi observado esse tipo de comportamento referente aos frutos de mogno, visto que o fruto é demasiadamente pesado, em comparação com os frutos de T. ciliata, e, possivelmente, a teia não suportaria o peso.

\subsection{CONCLUSÕES}

- A partir da análise dos frutos foi possível constatar a presença de H. grandella em várias árvores de mogno situadas em Brasília/DF;

- 95\% dos frutos de mogno caídos continham oríficios feitos pelo inseto e 36\% estavam com todas as sementes danificadas por $H$. grandella;

- Foram encontradas 180 lagartas de diferentes instares e 45 pupas de H. grandella no interior dos frutos.

\subsection{REFERÊNCIAS BIBLIOGRÁFICAS}

BRAGA SOBRINHO, R.; OLIVEIRA, M. A. S.; WARUMBY, J.; MOURA, J. I. L. 1998. Pragas da Gravioleira. In: BRAGA SOBRINHO, R.; CARDOSO, J. E.; FREIRE, F. C. O. 
Pragas de Fruteiras Tropicais de Importância Agroindustrial. Brasília: Embrapa-SPI; Fortaleza: Embrapa-CNPA, p. 131-141.

CORDEIRO, Y. E. M. 2012. Potencial de uso em recuperação de áreas degradadas: um estudo de três espécies nativas da Amazônia Oriental sob dois regimos hídricos. UFAM. 89 p.

GARCIA, A. H.; ROSA, J. A. M.; COSTA, M. G. G. 1980. Contribuição ao conhecimento do ataque de Pachymerus nucleorum Fabr., 1972 (Bruchidae: Coleoptera) em Syagrus oleraceae Mart. (Palmae). Anais da Escola de Agronomia e Veterinária, v. 10, p. 5-11.

GAZEL FILHO, A. B.; SILVA, R. A. 2003. Insetos prejudiciais à cultura da gravioleira (Annona muricata L. - Annonaceae) no Estado do Amapá, Brasil. Reunião Anual do Instituto Biológico, n. 16. Arquivos do Instituto Biológico, v. 70. CD-ROM.

GAZEL FILHO, A. B.; SILVA, R. A.; LIMA, J. A. de S. 2002. Pragas da gravioleira (Annona muricata L.) no Amapá. Macapá: Embrapa Amapá, Comunicado Técnico, n. 75.

GRIFFITHS, M. W. 2001. The biology and ecology of Hypsipyla shoot borers. In: FLOYD, R. B.; HAUXWELL, C. (Ed.) Hypsipyla Shoot Borers in Meliaceae: Proceedings of an International Workshop. Canberra: Australian Centre for International Agricultural Research, p. 74-80.

GRIJPMA, P.; GARA, R. I. 1970. Studies on the shootborer Hypsipyla grandella (Zeller): II. Host preference of the larva. Turrialba, v. 20, p. 241-247. 
GULLISON, R. E.; PANFIL, S. N. STRUOSE, J. J.; HUBBELL, S. P. 1996. Ecology and management of mahogany (Swietenia macrophylla King) in the Chimanes Forest, Neni, Bolivia. Botanical Journal of the Linnean Society, v. 122, p. 9-34.

JANZEN, D. H. 1971. Seed predation by animals. Annual Review of Ecology and Systematics, v. 2, p. 465-492.

LEMOS, W.P. 1997. Biologia e exigências térmicas de Euborellia annulipes (Lucas, 1847) (Dermaptera: Anisolabididae), predador do bicudo-do-algodoeiro. Dissertação de Mestrado, Universidade Federal da Paraíba, 119 p.

LIMA, A. C. 1940. Insetos do Brasil, Escola Nacional de Agronomia, Série Didática, nº 3.

PENNINGTON, T. D.; STYleS, B. T.; TAYLER, D. A. H. 1981. Meliaceae. Flora Neotropica Monograph, v. 28, p. 1-472.

PINTO, A. A.; TELES, B. R.; ANJOS, N.; COUCEIRO, S. R. M. 2013. Predação de sementes de andiroba [Carapa guianensis Aubl. e Carapa procera DC. (Meliaceae)] por insetos na Amazônia. Revista Árvore, v.37, n. 6, p. 1115-1123.

QUERINO, R. B.; TONINI, H.; MARSARO JR, A. L.; TELES, A. S.; COSTA, J. A. M. 2008. Predação de Sementes de Andiroba (Carapa spp.) por Hypsipyla ferrealis Hampson (Lepidoptera : Pyralidae) em Roraima. Boa Vista: Embrapa Roraima, Boletim de Pesquisa e Desenvolvimento, n. 5, 24 p. 
SILVA, F. A. S. 2013. Assistat, versão 7.6 beta.

Disponível em: http://www.assistat.com/indexp.html

SNOOK, L. K. 1998. Colheita sustentada da madeira de mogno (S. macrophylla) nas florestas de Yucatan de México. Conservação e desenvolvimento na floresta de Maya de Belize, de Guatemala e de México. In: PRIMACK, R. B.; ZUARRA, D.; GALlETT, H. A.; PONCIANO, I. Imprensa do Console, p. 61-80.

TAVERAS, R.; HILJE, L.; CARBALLO, M. 2004. Development of Hypsipyla grandella (Zeller) (Lepidoptera: Pyralidae) in response to constant temperatures. Neotropical Entomology, n. 33, p. 1-6.

THOMAZINI, M. J.; TEDESCHI, V. H. P.; MEIRA, J. R. de. 2011. Incidência e danos da broca-das-meliáceas, Hypsipyla grandella, em mogno, no interior paulista. Colombo: Embrapa Florestas, Comunicado Técnico, n. 280, 6 p.

VANIN, S. A.; GAIGER, F. 2005. A new spermophagous species of Heilipus Germar from the Amazonian Region (Coleoptera, Curculionidae, Molytinae). Revista Brasileira de Entomologia, v. 49, n. 2, p. 240-244.

WEATHERBASE, 2013. Disponível em: http://www.weatherbase.com/. Acessado em janeiro de 2014.

ZHANG, J.; DRUMMOND, F. A.; LIEBMAN, M.; HARTKE, A. 1997. Insect predation of seeds and plant population dynamics. Mafes Technical Bulletin, University of Maine, v. 163. 


\section{ESTABELECIMENTO DE CRIAÇÃO E BIOLOGIA DE Hypsipyla grandella Zeller (Lepidoptera: Pyralidae) ALIMENTADAS COM SEMENTES DE MOGNO (Swietenia macrophylla King)}

\subsection{RESUMO}

A broca-das-meliáceas, Hypsipyla grandella Zeller, é uma Lepidoptera que abrange praticamente todo o território brasileiro. Seus danos no mogno são tão intensos que inviabilizam o estabelecimento de plantios comerciais dessa espécie. Estudos visando o seu controle são fundamentais para que o sucesso do plantio do mogno em diferentes regiões seja viável e sustentável. Para isso, a criação massal do inseto é necessária para a realização dos bioensaios e estudos acerca de sua biologia. Com base nisso, este estudo teve como objetivo elaborar um método de criação massiva com base em uma dieta baseada em sementes de mogno. Foram utilizadas lagartas advindas de populações de mogno situadas em Brasília/DF e estas foram alocadas em recipientes plásticos com sementes de mogno. Foram avaliados aspectos morfológicos e morfométricos durante oito gerações sucessivas. As sementes de mogno propiciaram o fornecimento de insetos de boa qualidade para a realização de bioensaios, com pesos e tamanhos uniformes de acordo com cada instar, além de baixa taxa de deformação de adultos.

Palavras-chave: entomologia florestal, praga, bioensaio, laboratório. 


\section{BREEDING AND BIOLOGY OF Hypsipyla grandella Zeller (Lepidoptera: Pyralidae) FED WITH MAHOGANY SEEDS (Swietenia macrophylla King)}

\subsection{ABSTRACT}

The shoot borer, Hypsipyla grandella Zeller, is a Lepidopteran that practically covers the entire Brazilian territory. Its damage to mahogany is so intense that it can prevent establishment of commercial plantations of the species. Studies of its control are critical for mahogany planting in different regions to be feasible and sustainable. To conduct bioassays and studies of this insect's biology, mass rearing is necessary. This study aimed to develop a method of mass rearing based on a diet of mahogany seeds. Caterpillars arising from mahogany populations located in Brasilia, Brasil were placed in plastic containers containing mahogany seeds. Morphological and morphometric aspects were evaluated through eight successive generations. The mahogany seeds produced a good supply of quality insects for performance of bioassays, with uniform sizes and weights for each instar and a low adult deformation rate.

Keywords: forest entomology, pest, bioassay, laboratory. 


\subsection{INTRODUÇÃO}

O gênero Hypsipyla é composto por 11 espécies, dentre as quais cinco se destacam por atacar árvores de interesse econômico, sobretudo representantes da família Meliaceae. Segundo Bradley (1968), H. robusta Moore é encontrada na África, Ásia e Austrália, $H$. ferrealis Hampson na América Central e norte da América do Sul, H. grandella na América Central e América do Sul, H. albopartalis Hampson e H. areboruna Meiryck na África. Hypsipyla robusta ataca os gêneros Khaya, Toona e Entandrophragma e H. grandella os gêneros Swietenia, Cedrela e Carapa. Hypsipyla grandella e H. robusta são consideradas as principais pragas do gênero (Grijpma, 1974).

Na família Meliaceae, 13 gêneros são alvos de $H$. grandella. No Brasil, ocorrem em mogno (Swietenia macrophylla King), cedro (Cedrela odorata L.) e andiroba (Carapa guianensis Aubl.), atacando ramos, brotos, folhas, frutos, casca e até mesmo a raiz (Yamazaki et al., 1990; Taveras et al., 2004).

O principal dano do inseto em árvores de mogno consiste na destruição do broto terminal em mudas e árvores novas, devido à entrada e escavação de galerias pelas lagartas (Grijpma \& Roberts, 1976). Os sintomas do ataque da lagarta são representados por exsudação de goma, presença de folhas secas em meio à folhagem verde e emissão de novos ponteiros a cada ataque consecutivo, que posteriormente também serão atacados (Silva, 1985; Griffiths, 2000; Ohashi et al., 2000). O crescimento de um tronco retilíneo é fortemente prejudicado (Grijpma \& Roberts, 1976; Ohashi et al., 2002), com perda em altura de até 35\% nos primeiros anos (Ohashi et al., 2002). Ataques repetitivos e intensos poderão causar a morte da planta.

Em uma revisão feita por Lunz et al. (2009), os principais métodos de controle pesquisados para o controle da broca são o uso de genótipos resistentes ao inseto; manejo silvicultural por meio da interferência na localização da planta hospedeira, redução da 
adequabilidade hospedeira, aumento de inimigos naturais e incremento da altura da planta; uso de semioquímicos; e o controle biológico, com o uso de fungos, vespas, nematoides e bactérias. O uso de inseticidas convencionais tem sido desaconselhável para o controle da broca por razões como o hábito do inseto (críptico), a natureza dos danos (internos na planta), fatores climáticos (pluviosidade intensa na região de ocorrência natural) e o longo período de proteção necessário que perdura quase todo o ciclo de vida da planta, que o torna oneroso, impraticável e danoso para o meio ambiente (Wylie, 2001; Mahroof et al., 2002).

A criação do inseto a base de uma dieta artificial é difícil. Estudos baseados em diferentes dietas adaptadas de outros lepidópteros foram realizados, porém as lagartas ficaram pequenas e com baixo peso, as pupas deformadas e os adultos inférteis (Vargas et al., 2001).

Devido a sua elevada importância comercial, ecológica e paisagística, o interesse de se realizar pesquisas com o objetivo de preservar, conservar e garantir o uso sustentável do mogno é evidente, sendo necessárias pesquisas com o intuito de diminuir os prejuízos causados por $H$. grandella. A partir disso, a criação do inseto torna-se necessária para a realização de bioensaios de mortalidade e, assim, verificar a eficiência das formas de controle.

Este trabalho teve como objetivo estabelecer um método de criação massal de $H$. grandella.

\subsection{MATERIAL E MÉTODOS}

As lagartas foram obtidas por meio de coleta em plantas de mogno situadas na Asa Norte, Brasília/DF e criadas no Laboratório de Bactérias Entomopatogênicas da Embrapa Recursos Genéticos e Biotecnologia (CENARGEN). Essas lagartas foram colocadas em recipientes de plástico com capacidade de $1000 \mathrm{~mL}$ contendo sementes de mogno e alimentadas até a sua fase de pupa. 
Previamente, foram realizados ensaios com objetivo de verificar qual o tipo de dieta seria mais adequado ao desenvolvimento do inseto, utilizando aproximadamente 20 gramas de folhas de mogno jovens, 20 gramas de alas da semente e 20 gramas de sementes de mogno inteiras. Uma dieta artificial idealizada por Vargas et al. (2001) também foi testada. Todas as dietas foram trocadas de dois em dois dias em todas as gerações, com o objetivo das lagartas sempre continuarem se alimentando. $\mathrm{O}$ delineamento experimental foi inteiramente casualizado, com cinco repetições e 10 lagartas por tratamento. As lagartas foram observadas até o último ínstar, onde elas foram pesadas (mg) e medidas (mm).

Após definida a dieta que permitisse o melhor desenvolvimento de $H$. grandella, iniciou-se o procedimento de estabelecimento de criação do inseto. Assim, as mariposas advindas das pupas foram dispostas em recipientes de plástico revestidos com papel toalha e recobertos com tecido do tipo "morim" para a oviposição. Como dieta, foi empregada a solução de mel a $10 \%$ oferecida sobre chumaço de algodão disposto em um copo plástico de 50 mL e substituído a cada dois dias.

Os ovos foram retirados do tecido e do papel e colocados em um recipiente contendo sementes para que tão logo emergissem, as lagartas já se alimentassem. A dieta foi trocada a cada três dias e as lagartas transferidas para outro recipiente de maior tamanho. Próximo à pupação, as lagartas eram transferidas para um recipiente contendo folhas de mogno. As pupas, após a separação por sexo foram, então, transferidas na proporção de 1:1 para gaiolas plásticas, conforme descritas anteriormente, e todo o processo reiniciado.

Durante oito gerações subsequentes foram avaliados:

1. Duração média do período (dias) larval, pupal, de adulto e de ovo de 50 indivíduos;

2. Peso (mg) e o comprimento ( $\mathrm{mm})$ de 50 lagartas de último instar;

3. Peso (mg) e o comprimento (mm) de 50 pupas; 
4. Número de adultos (machos e fêmeas) e de adultos deformados, baseado em características morfológicas, como o formato da cabeça e das antenas. Foram considerados adultos deformados aqueles que foram morfologicamente diferentes das características originais (Monte, 1933).

5. Comparação do número de ovos de 25 fêmeas, colocadas com 25 machos.

Os dados foram submetidos ao teste de variância ANOVA ao teste de Tukey $(\mathrm{p}<0,05)$, através do programa estatístico Assistat. Os resultados acerca do uso de diferentes dietas, como também a biologia e o comportamento de $H$. grandella sob confinamento foram também comparados com os obtidos na literatura e avaliados quanto à eficácia do uso de sementes de mogno como forma de dieta natural.

\subsection{RESULTADOS E DISCUSSÃO}

As lagartas colocadas em dieta artificial não comeram, logo não se alimentaram. A dieta artificial não foi ingerida pelas lagartas mesmo após a adaptação dos ingredientes, de tal forma a incluir sementes de mogno, porém não houve alimentação por parte das lagartas. Dessa forma, a dieta artificial foi descartada. Assim, foi utilizada dieta natural à base sementes de mogno, ala e folhas.

Das 180 lagartas coletadas, 100 do $6^{\circ}$ instar foram destinadas para a criação (Figura 1). Destas, 86 originaram adultos, onde 44 eram fêmeas e 25 foram usadas. Elas depositaram aproximadamente 550 ovos, com 95\% de viabilidade. As lagartas da primeira geração (F1) emergiram após três/quatro dias e tiveram, em média, 15 dias de período larval e 10 de período pupal

Uma única fêmea fertilizada de H. grandella pode colocar de 30 a 200 ovos durante três a quatro dias (Grijpma, 1971; Berti Filho, 1973; Sarmento Junior, 2001; Ohashi et al.,2002; Silva, 2003) e mais de 1.000 ovos em condições de laboratório (Grijpma \& Roberts, 
1976). A queda do número de ovos a partir da F3 (Figura 2) ocorreu provavelmente devido à “deriva genética", ou seja, perda de variabilidade genética durante as sucessivas gerações, o que resulta numa queda do número de indivíduos férteis e saudáveis (Lande \& Barrowclough, 1987; Cassel et al, 2001). A solução para esse problema seria a introdução de indivíduos selvagens na colônia, de preferência de outras regiões de ocorrência, aumentando a chance de cruzamento entre indivíduos sem grau de parentesco evidente.
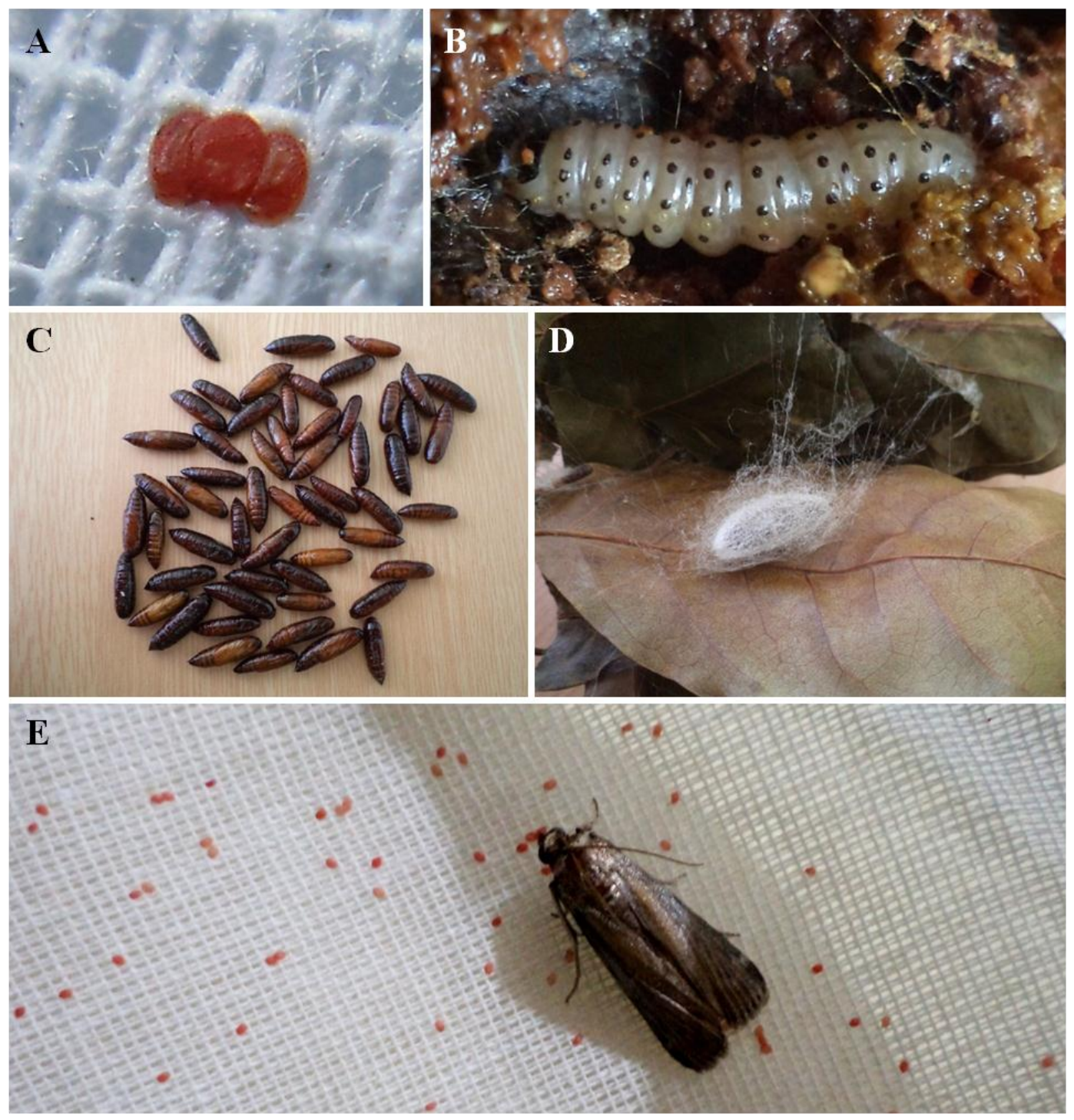

Figura 1 (A - E). Criação de Hypsipyla grandella. A) Ovos férteis; B) Lagarta de $3^{\circ}$ instar; C) Pupas com a teia removida; D) Pupário com teia de proteção; E) Inseto adulto (fêmea) e ovos. 


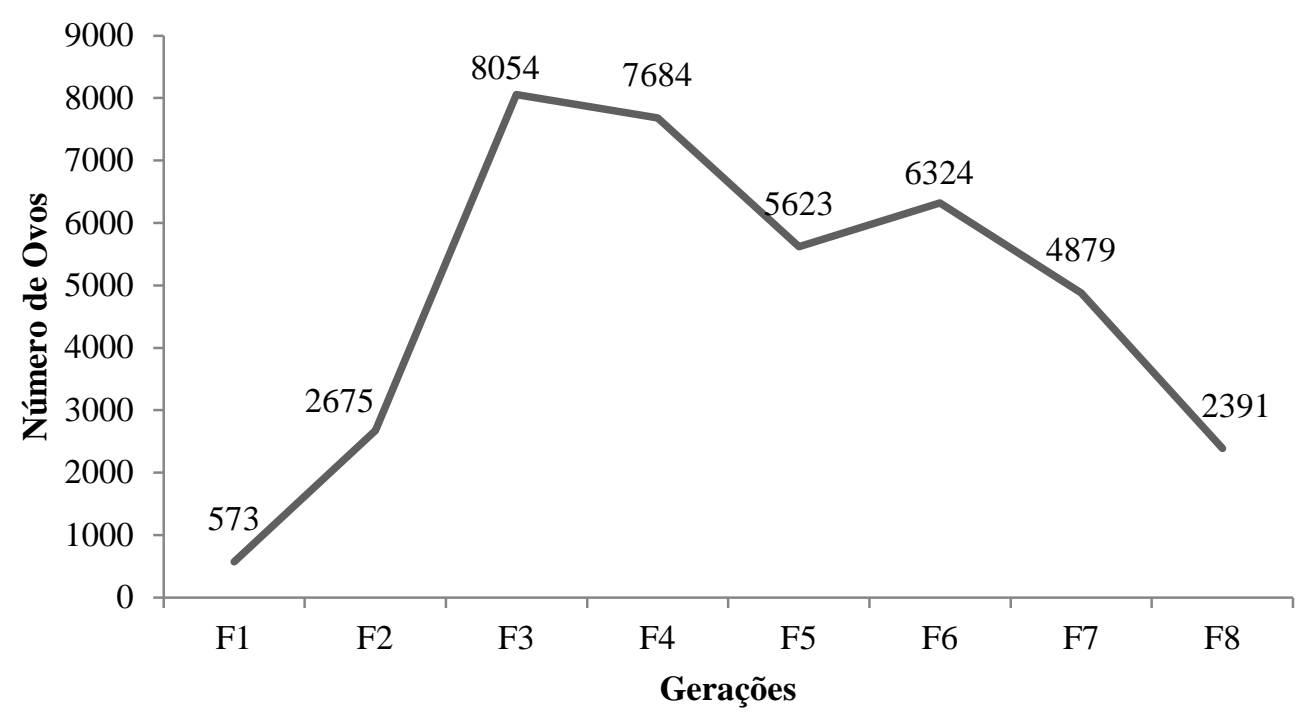

Figura 2. Número de ovos por sucessivas gerações de Hypsipyla grandella.

A criação conjunta de várias lagartas em um mesmo recipiente é viável. As lagartas não demonstraram nenhum grau de canibalismo quando criadas em um recipiente de $500 \mathrm{~mL}$ de capacidade, diferindo de Vargas et al. (2001), onde os autores propõem a individualização das lagartas a partir do terceiro instar.

Os resultados dos testes com as diferentes dietas naturais evidenciaram um melhor crescimento do inseto quando alimentados com sementes de mogno. Isso pode ocorrer pelo fato da semente ser mais rica em ácidos graxos (Chan et al., 1976), com ácido palmítico, ácido palmitólico, ácido oleico e ácido linoleico, ácidos esses que são considerados benéficos para a saúde (Suliman et al., 2013) e também por conferir, após a penetração da lagarta, proteção contra predadores ou fornecer um ambiente similar ao das galerias que elas fazem nos ponteiros. As lagartas de último ínstar apresentaram maior peso e comprimento com base em uma dieta natural de sementes quando comparadas com outras dietas, como evidencia a Tabela 1. 
Tabela 1. Peso e tamanho de lagartas do último instar de Hypsipyla grandella quando mantidas em diferentes dietas.

\begin{tabular}{ccc}
\hline Dieta & Peso $(\mathrm{mg})$ & Comprimento $(\mathrm{mm})$ \\
\hline Alas & $0,0 \mathrm{c}$ & $0,0 \mathrm{~b}$ \\
Artificial & $0,0 \mathrm{c}$ & $0,0 \mathrm{~b}$ \\
Folhas & $116,25 \mathrm{~b}$ & $26 \mathrm{a}$ \\
Sementes & $262,53 \mathrm{a}$ & $28 \mathrm{a}$ \\
\hline * Médias seguidas da mesma letra não diferem estatisticamente entre si, ao nível de significância de 5\% - Tukey.
\end{tabular}

As sementes de mogno podem apresentar uma composição de nutrientes e proteínas diferenciadas quando comparadas com a ala e as folhas, o que explica o diferencial de peso das lagartas.

Os ovos, assim que colocados, apresentaram coloração branca a amarelada tornandose vermelhos após 24 horas, quando férteis. Apresentam formato ovalado a elíptico, com 0,6 $1,1 \mathrm{~mm} \times 0,5-0,8 \mathrm{~mm}$ em média, com leves depressões em sua superfície quando vistos sob microscópio óptico (Figura 3), estruturas denominadas faveoladas ou alveoladas, corroborando as observações obtidas por Griffiths (1997) e Gallo et al. (2002). Os ovos foram colocados, em sua maioria, de maneira individualizada, porém, foi possível observar grupos de até 5 ovos. Costa (2000) observou uma postura de até 4 ovos próxima das axilas foliares, porém em casos isolados. O período de incubação dos ovos durou de 3 a 5 dias em condições ambiente de temperatura $\left(26-28{ }^{\circ} \mathrm{C}\right)$. Observações semelhantes foram encontradas por Griffiths (1997), em populações naturais da Austrália. 


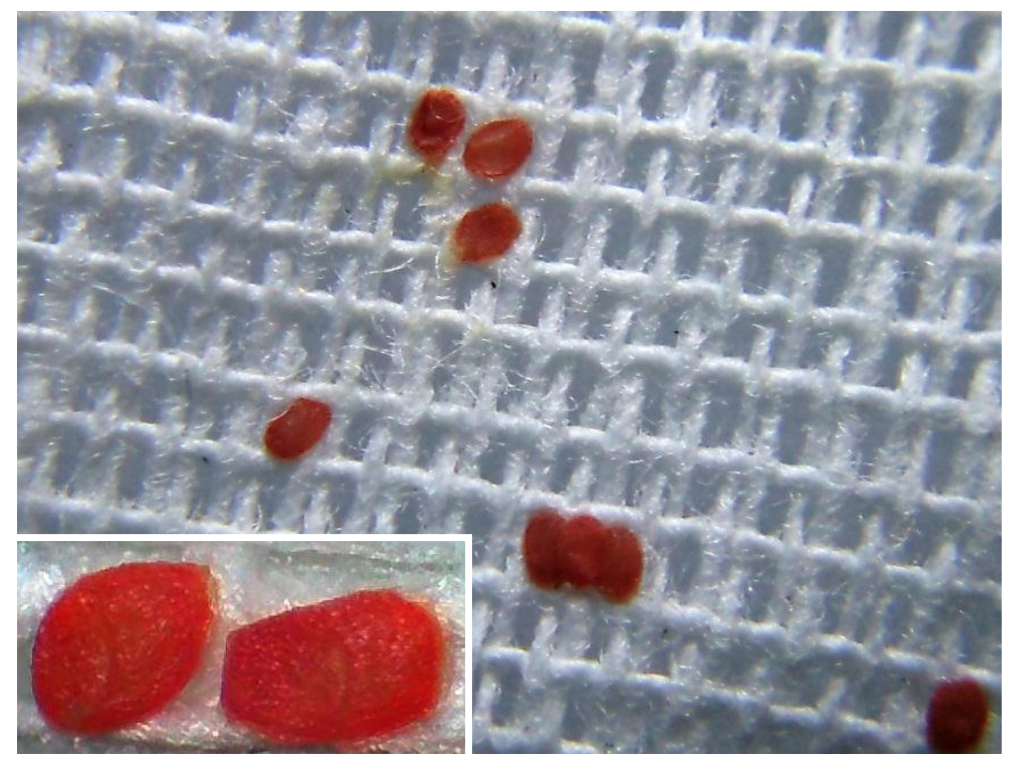

Figura 3. Postura individual e em grupo de Hypsipyla grandella em tecido tipo "morim" e detalhes do formato do ovo visto em microscopia estereoscópica.

As lagartas de primeiro ínstar apresentavam coloração amarelada a amarronzada com o escudo protorácico enegrecido, contendo vários pequenos tubérculos escuros. À medida que as lagartas foram avançando em seu ciclo biológico, adquiriram coloração bege a amarronzada ou rósea, dependendo do instar. A lagarta de último instar apresentou coloração azulada, com cabeça acastanhada e escudo protorácico escuro. Sobre o corpo, foi possível visualizar inúmeros tubérculos pretos, em número de 10, em média, com um pêlo da mesma cor em cada um deles, corroborando as observações feitas por Monte (1933). O tamanho e o peso no último instar, de lagartas de $H$. grandella alimentadas com uma dieta natural a base de sementes de mogno, durante sucessivas gerações, indica que a dieta a base de sementes não influencia suas características morfométricas (Tabela 2). 
Tabela 2. Média do comprimento e peso de lagartas de último instar de Hypsipyla grandella mantidas em dieta à base de sementes de mogno, após oito gerações sucessivas.

\begin{tabular}{ccc}
\hline Geração & Peso $(\mathrm{mg})$ & Comprimento $(\mathrm{mm})$ \\
\hline $1^{\circ}$ & $257,3 \pm 5,84 \mathrm{a}$ & $27 \pm 3 \mathrm{a}$ \\
$2^{\circ}$ & $263,7 \pm 6,87 \mathrm{a}$ & $26 \pm 3 \mathrm{a}$ \\
$3^{\circ}$ & $260,1 \pm 5,98 \mathrm{a}$ & $27 \pm 4 \mathrm{a}$ \\
$4^{\circ}$ & $261,9 \pm 6,32 \mathrm{a}$ & $28 \pm 3 \mathrm{a}$ \\
$5^{\circ}$ & $259,1 \pm 6,43 \mathrm{a}$ & $25 \pm 4 \mathrm{a}$ \\
$6^{\circ}$ & $256,9 \pm 6,41 \mathrm{a}$ & $27 \pm 3 \mathrm{a}$ \\
$7^{\circ}$ & $249,8 \pm 6,55 \mathrm{a}$ & $28 \pm 4 \mathrm{a}$ \\
$8^{\circ}$ & $255,5 \pm 6,59 \mathrm{a}$ & $28 \pm 3 \mathrm{a}$ \\
* Médias seguidas da mesma letra não diferem estatisticamente entre si, ao nível de significância de 5\% - Tukey.
\end{tabular}

As pupas de $H$. grandella apresentaram coloração amarronzada e brilhante, envoltas por um casulo de proteção feito com teia branca, com crisálidas do tipo obtecta. Tanto o macho quanto a fêmea apresentaram variegação na coloração, sendo mais escuros na parte superior e mais claros na parte inferior, podendo, em alguns casos, serem totalmente marrons ou totalmente castanhos. As pupas apresentaram valores médios de comprimento de $19 \mathrm{~mm}$ e peso de 191,96 mg, conforme representado na Tabela 3. Sanchez (1964) e Roovers (1971) encontraram pupas medindo $20 \mathrm{~mm}$ de comprimento por $5 \mathrm{~mm}$ de largura, em média.

A duração da fase pupal foi de 8 a 12 dias, com média de 9 dias, corroborando os resultados de Berti Filho et al. (1992), Sarmento Jr. (2001) e Almeida (2005). 
Tabela 3. Peso e tamanho de pupas de Hypsipyla grandella mantidas em dieta natural a base de sementes de mogno em sucessivas gerações.

\begin{tabular}{ccc}
\hline Geração & Peso $(\mathrm{mg})$ & Tamanho $(\mathrm{mm})$ \\
\hline $1^{\circ}$ & $192,4 \pm 6,23 \mathrm{a}$ & $18 \pm 4 \mathrm{a}$ \\
$2^{\circ}$ & $193,9 \pm 7,57 \mathrm{a}$ & $20 \pm 3 \mathrm{a}$ \\
$3^{\circ}$ & $190,7 \pm 11,27 \mathrm{a}$ & $18 \pm 4 \mathrm{a}$ \\
$4^{\circ}$ & $190,8 \pm 10,88 \mathrm{a}$ & $17 \pm 4 \mathrm{a}$ \\
$5^{\circ}$ & $192,1 \pm 9,03 \mathrm{a}$ & $19 \pm 3 \mathrm{a}$ \\
$6^{\circ}$ & $189,3 \pm 7,98 \mathrm{a}$ & $18 \pm 4 \mathrm{a}$ \\
$7^{\circ}$ & $188,6 \pm 8,54 \mathrm{a}$ & $20 \pm 3 \mathrm{a}$ \\
$8^{\circ}$ & $191,1 \pm 7,75 \mathrm{a}$ & $18 \pm 4 \mathrm{a}$ \\
\hline * Médias seguidas da mesma letra não diferem estatisticamente entre si, ao nível de significância de 5\% - Tukey.
\end{tabular}

Os adultos de $H$. grandella apresentaram coloração cinza nas asas anteriores e branca transparente nas posteriores, o que está de acordo com a descrição de Alves (2002). As fêmeas apresentaram maior longevidade (6,3 dias) em comparação com os machos (4,2 dias). Berti Filho (1973) relatou longevidade de 4,6 dias para fêmeas e de 2,9 dias para machos. Newton et al. (1993) encontrou valores variáveis de 8 dias para fêmeas e 6 dias para machos e Sarmento Jr. (2001) relatou longevidade de 4,2 dias para fêmeas e 3,8 dias para machos. As diferenças podem estar relacionadas a dieta utilizada na alimentação e a temperatura em que foram mantidas.

Durante a avaliação dos ensaios, foi observado um comportamento de vibração das asas nas fêmeas, sem alçar voo. Grijpma (1971) explica esse fenômeno como liberação e propagação de feromônio atraente sexual para os machos.

O número de adultos machos e fêmeas em sucessivas gerações, feitas a partir da análise de 50 pupas aleatórias até a F8, pode ser visualizada na Figura 4. É possível inferir que a razão sexual é praticamente de 1:1 nas várias gerações, corroborando os dados Newton et al. (1993). 


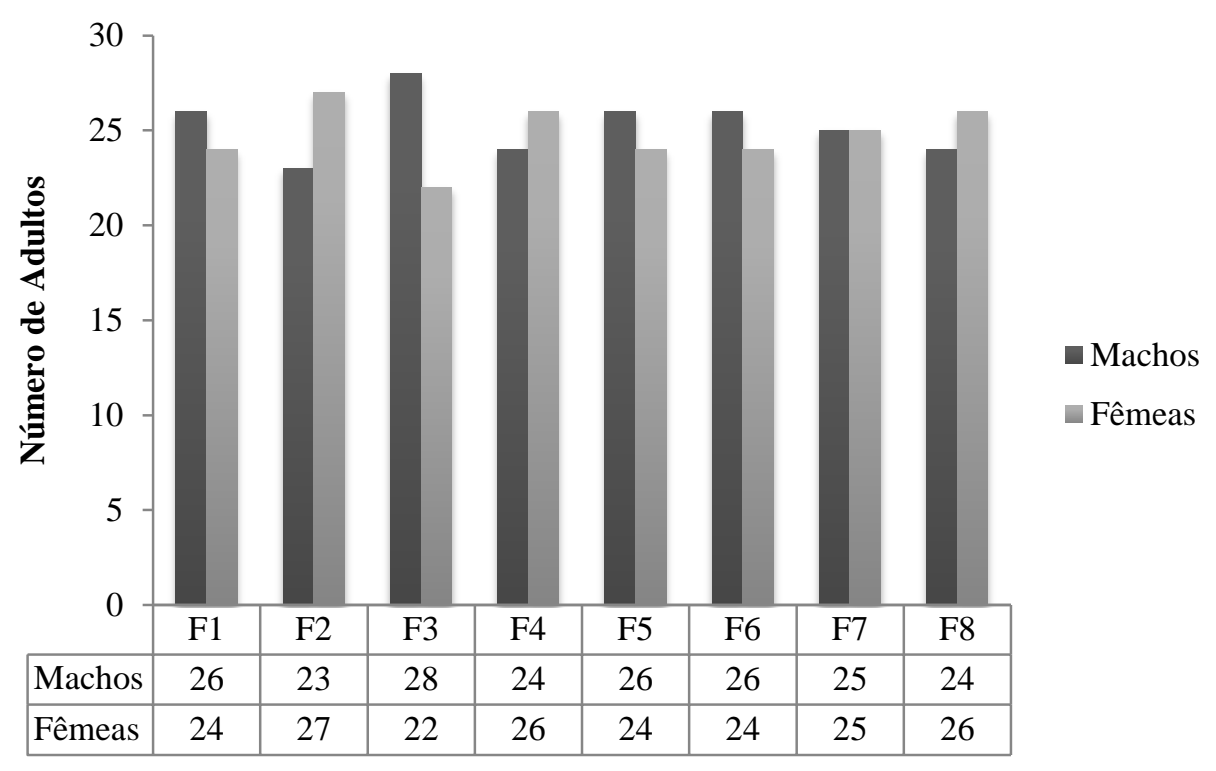

Figura 4. Número de adultos machos e fêmeas de Hypsipyla grandella, durante oito gerações sucessivas.

O número de adultos deformados foi contabilizado durantes 8 gerações sucessivas, e está representado na Figura 5. A quarta geração foi a que apresentou o maior número de insetos deformados, cinco indivíduos ou $10 \%$ do total analisado. Dietas deficientes em ácidos graxos, como os ácidos linoleicos e linolênicos, podem resultar em adultos com asas deformadas (Parra, 2001). Entretanto, alguns adultos estavam deformados possivelmente por causas naturais. Os resultados indicam que a dieta a base de sementes de mogno apresenta nutrientes essenciais para um bom desenvolvimento do inseto, contribuindo para uma baixa formação de adultos deformados. 


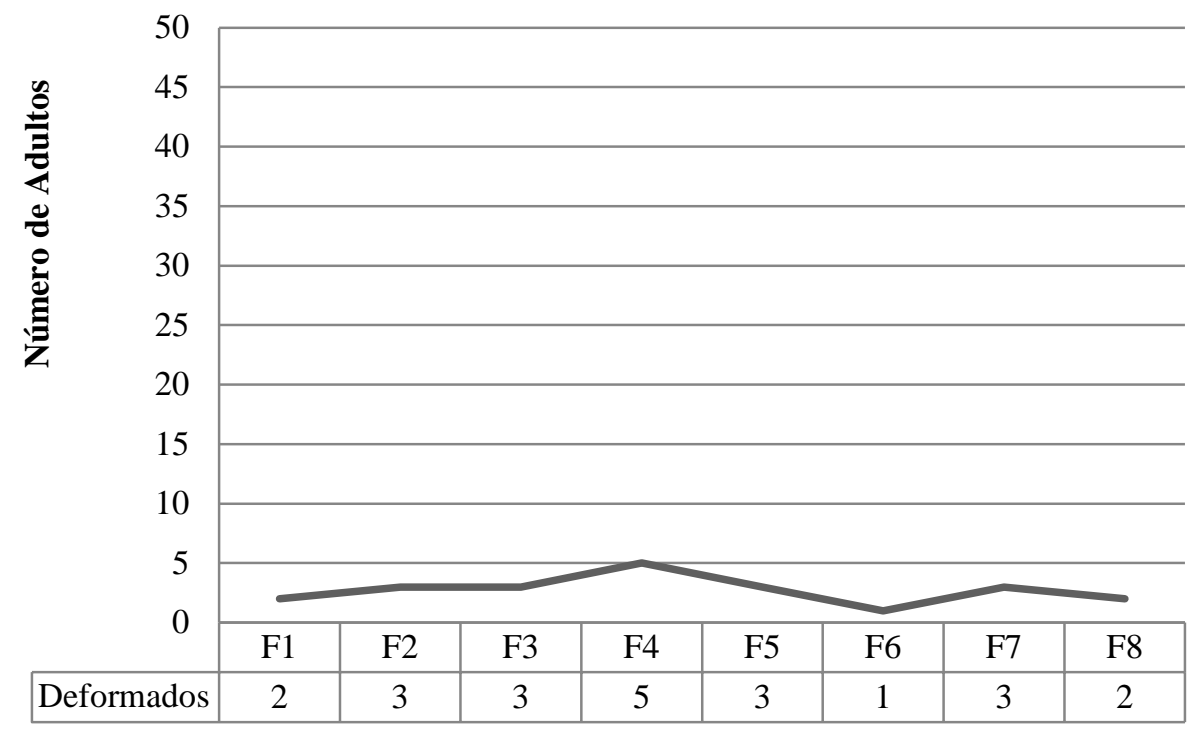

Figura 5. Número de adultos de Hypsipyla grandella deformados quando alimentados com sementes de mogno, durante sucessivas gerações, até a F8.

\subsection{CONCLUSÕES}

- O estabelecimento de uma criação de Hypsipyla grandella a base de sementes de mogno é possível, rápido e prático;

- O uso dessa dieta propiciou insetos de boa qualidade para futuros bioensaios, com lagartas de peso e tamanhos uniformes e baixa taxa de adultos deformados.

\subsection{REFERÊNCIAS BIBLIOGRÁFICAS}

ALMEIDA, G. B. 2005. Criação contínua de Hypsipyla grandella (Zeller, 1848) (Lepidoptera: Pyralidae) com dieta artificial. Dissertação (Mestrado em Agronomia) Universidade Federal Rural da Amazônia, Belém, 63 f.

ALVES, M. Z. N. 2002. Efeito letal de Toona ciliata M. J. Roem, folhas maduras de mogno (Swietenia macrophylla) e seus extratos à lagarta de Hypsipyla grandella Zeller 
em laboratório. Dissertação (Mestrado em Agronomia) - Faculdade de Ciências Agrárias do Pará, Belém. 53 f.

BERTI FILHO, E. Observações sobre a biologia de Hypsipyla grandella (Zeller, 1848) (Lepidoptera, Phycitidae). 1973. Dissertação (Mestrado em Entomologia). Escola Superior de Agricultura Luiz de Queiroz, Universidade de São Paulo, Piracicaba, São Paulo. 108 f.

BERTI FILHO, E.; BATISTA, G.C; ALVES, S.B. 1992. Curso de Entomologia Aplicada a Agricultura-pragas de espécies florestais arbóreas. Piracicaba, FEALQ, 760p.

BRADLEY, J. D. 1968. Description of two genera and species of Phycitinae associated with Hypsipyla robusta (Moore) on Meliaceae in Nigeria (Lepidoptera, Pyralidae). Bulletin of Entomological Research, London, v.57, n.4, p.605-613.

CASSEL, A.; WINDIG, J.; NYLIN, S.; WIKLUND, C. 2001. Effects of Population Size and Food Stress on Fitness-Related Characters in the Scarce Heath, a Rare Butterfly in Western Europe. Conservation Biology, Boston, v.15, n.6, p.1667.

CHAN, K. C.; TANG, T. S.; TOH, H. T. 1976. Isolation of swietenolide diacetate from Swietenia macrophylla. Phytochesmistry, v.15, p.429-430.

COSTA, M. S. S. 2000. Controle de Hypsipyla grandella Zeller (broca do mogno) utilizando a planta resistente Toona ciliata Roem (cedro australiano) e métodos mecânicos e cultural no plantio de Swietenia macrophylla King (mogno). Dissertação (Mestrado em Agronomia) - Faculdade de Ciências Agrárias do Pará. 51p. 
GALlO, D.; NAKANO, O.; SILVEIRA NETO, S.; CARVALHO, R. P. L.; BATISTA, G. C.; BERTI FILHO, E.; PARRA, J. R. P.; ZUCCHI, R. A.; ALVES, S. B.; VENDRAMIN, J. D.; MARCHINI, L. C.; LOPES, J. R. S.; OMOTO, C. 2002. Entomologia Agrícola. FEALQ, Piracicaba, v.10, 920 p.

GRIFFITHS, M. W. 1997. The biology and host relations of the red cedar tip moth, Hypsipyla robusta Moore (Lepidoptera: Pyralidae) in Australia. Ph.D. Thesis, University of Queensland, Brisbane. 182 p.

GRIFFITHS, M. W. 2000. The biology and host relations of the red cedar tip moth, Hypsipyla robusta, in Australia. In: SNELL, A.; VIZE, S. (Ed.) Opportunities for the New Millennium: Proceedings of the Australian Forest Growers Biennal Conference. Canberra: Australian Forest Growers, p.135-140.

GRIJPMA, P. 1971. Studies on the shootborer Hypsipyla grandella Zeller. Observations on a rearing technique and on host selection behavior of adults in captivity. Turrialba, v.21, p.202-213.

GRIJPMA, P. 1974. Contributions to an integrated control program of Hypsipyla grandella (Zeller) in Costa Rica. Doctoral Thesis. State Agriculture University of Wageningen, Holland.

GRIJPMA, P.; ROBERTS, S. C. 1976. Biological and chemical screening for the basis of resistance of Toona ciliate M. J. Roem. var australis. In: WHITMORE, J. L (Ed.) Studies on 
the shootborer Hypsipyla grandella (Zeller) Lep. Pyralidae. Vol. III. San José: Centro Agronómico Tropical de Investigación y Enseñanza, p.103-109.

LANDE, R.; G. F. BARROWCLOUGH. 1987. Effective population size, genetic variation, and their use in population management, p. 87-123. In: M. E. Soule (Ed.). Viable populations for conservation. Cambridge, Cabridge University Press.

LUNZ, A. M; THOMAZINI, M. J.; MORAES, M. C. B.; NEVES, E. J. M.; BATISTA, T. F. C.; DEGENHARDT, J.; SOUSA, L. A.; OHASHI, O. S. 2009. Hypsipyla grandella em Mogno (Swietenia macrophylla): situação atual e perspectivas. Pesquisa Florestal Brasileira, n.59, p.45-55.

MAHROOF, R. M.; HAUXWELL, C.; EDIRISINGHE, J. P.; WATT, A. D.; NEWTON, A. C. 2002. Effects of artificial shade on attack by the mahogany shoot borer, Hypsipyla robusta (Moore). Agricultural and Forest Entomology, Midlothian, n.4, p.283-292.

MONTE, O. 1933. Hypsipyla grandella Zeller, uma praga da silvicultura. Revista de Entomologia, v.50, p.281-285.

NEWTON, A.C.; BAKER, P.; RAMMARINE, S.; MESEN, J.F; LEAKEY, R.R.B. 1993. The mahogany shoot borer - prospects for control. Forest Ecology and Management, v.57, p.301-328.

OHASHI, O. S.; COSTA, M. S. S.; SILVA, J. N. M.; SILVA, M. F. G. G. 2000. Resistência do tipo antibiose apresentada pelas folhas novas de Toona ciliata M. J. Roem às lagartas 
de Hypsipyla grandella Zeller. Comunicado Técnico, 48. Belém: Embrapa Amazônia Oriental. $3 \mathrm{p}$.

OHASHI, S. T.; SILVA, J. N. M.; SILVA, M. E. C. E.; COSTA, M. S. S.; SARMENTO JUNIOR, R. G.; SANTOS, E. B.; ALVES, M. Z. N.; PESSOA, A. M. C.; SILVA, T. C. O.; BITTENCOURT, P. R. G.; BARBOSA, T. C.; SANTOS, T. M. 2002. Manejo Integrado da Broca do Mogno Hypsipyla grandella Zeller (Lep. Pyralidae). In: POLTRONIERI, L. S.; TRINDADE, D. R. Manejo integrado das principais pragas e doenças de cultivos amazônicos. Belém: Embrapa Amazônia Oriental, 304 p.

PARRA, J. R. P. 2001. Técnicas de criação de insetos para programas de controle biológico. ESALQ/FEALQ. Piracicaba, São Paulo, 134 p.

ROOVERS, M. 1971. Observaciones sobre el ciclo de vida de Hypsipyla grandella (Zeller) en Barinitas, Venezuela. Boletín del Instituto Forestal Latino-Americano de Investigación y Capacitacion, v.38, p.1-46.

SÁNCHEZ, J.R. 1964. Investigación preliminar sobre la biología, ecología y control de Hypsipyla grandella (Zeller). Boletín Del Instituto Forestal Latino Americano de Investigación y Capacitacion, v.16, p.54-77.

SARMENTO JUNIOR, R. G. 2001. Biologia de Hypsipyla grandella (Zeller, 1848) e avaliação da resistência de Swietenia macrophylla King, Cedrela odorata L., Toona ciliata Roem e Toona sp. à broca das meliáceas em laboratório. Dissertação (Mestrado em Agronomia), Instituto de Ciências Agrárias, Faculdade de Ciências Agrárias do Pará, 60 f. 
SILVA, N. M. 1985. Características biológicas e demográficas de Hypsipyla grandella (Zeller, 1848) (Pyralidae, Lepidoptera) e níveis de infestação sob dois sistemas de plantio de Carapa guianensis Aubl. (Meliaceae) no Amazonas. Dissertação (Mestrado em Ciências Biológicas), Departamento de Ciências Fundamentais e Desenvolvimento Agrícola, Instituto Nacional de Pesquisas da Amazônia, 103 f.

SILVA, T. C. O. 2003. Dieta artificial para a criação de Hypsipyla grandella (Zeller, 1848) (Lepidoptera), broca das meliáceas, em laboratório. Dissertação (Mestrado em Agronomia), Instituto de Ciências Agrárias, Universidade Federal Rural da Amazônia, 73 f.

SULIMAN, M. B.; NOUR, A. H.; YUSOFF, M. M.; NOUR, A. H.; KUPPUSAMY, P.; YUVARAJ, A. R. \& ADAM, M. S. 2013. Fatty acid composition and antibacterial activity of Swietenia macrophylla King seed oil. African Journal of Plant Science, v.7, n.7, p.300-303.

TAVERAS, R.; HILJE, L. CARBALLO, M. 2004. Development of Hypsipyla grandella (Zeller) (Lepidoptera: Pyralidae) in response to constant temperatures. Neotropical Entomology, n.33, p.1-6.

VARGAS, C; SHANNON, P. J.; TAVERAS, R.; SOTO, F.; HILJE, L. 2001. Un nuevo método para la cría masiva de Hypsipyla grandella. Manejo Integrado de Plagas, n.62, p.14.

WYLIE, F. R. 2001. Control of Hypsipyla spp. shoot borers with chemical pesticides: a review. In: FLOYD, R. B.; HAUXWELL, C. (Ed.) Hypsipyla Shoot Borers in Meliaceae: 
Proceedings of an International Workshop. Canberra: Australian Centre for International Agricultural Research, p.109-117.

YAMAZAKI, S.; TAKETANI, A.; FUJITA, K. VASQUES, C.; IKEDA, T. 1990. Ecology of Hypsipyla grandella and its seasonal changes in population density in Peruvian Amazon forest. Japan Agricultural Quarterly, n.24, p.149-155. 


\section{CAPÍtULO 3}

\section{OCORRÊNCIA NATURAL E PATOGENICIDADE DE UM ISOLADO DE Beauveria bassiana (Balsamo) Vuill. À Hypsipyla grandella Zeller (Lepidoptera: Pyralidae) COLETADO EM BRASÍLIA, DISTRITO FEDERAL}

\subsection{RESUMO}

Um dos principais entraves para o estabelecimento do plantio de mogno é a ocorrência da Hypsipyla grandella Zeller, que ataca o broto terminal em mudas e árvores novas, formando galerias em seu interior Esse trabalho teve como objetivo isolar, identificar e verificar a capacidade patogênica de fungos associados à $H$. grandella em Brasília, Brasil. Para isso, 200 frutos atacados pelo inseto foram coletados e analisados. Uma lagarta com sintoma de infecção fúngica foi encontrada. A lagarta sintomática foi colocada em câmara úmida para maior formação de esporos e então, colônias puras foram obtidas a partir de diluições seriadas e repicagens sucessivas do fungo. Foi feita a sua caracterização molecular, morfológica e patogênica. O isolado foi identificado como Beauveria bassiana (Balsamo) Vuillemin, um entomopatógeno muito utilizado em programas de controle biológico. As colônias puras eram de cor branca e, ao microscópio óptico, apresentavam conídios unicelulares, células conidiogênicas holoblásticas com dentículos conspícuos, caracterizando a espécie. Quanto ao teste de patogenicidade, o isolado se mostrou eficaz, com mortalidade de $70 \%$ de lagartas recém-eclodidas. Este é o primeiro relato de um fungo entomopatogênico encontrado em $H$. grandella no Distrito Federal. O isolado foi incorporado na Coleção de Fungos de Invertebrados da Embrapa Recursos Genéticos e Biotecnologia.

Palavras-chave: entomologia florestal, controle biológico, fungo entomopatogênico. 


\section{NATURAL OCCURRENCE AND PATHOGENICITY OF AN ISOLATE OF Beauveria bassiana (Balsamo) Vuill. AT Hypsipyla grandella Zeller (Lepidoptera: Pyralidae) COLLECTED IN BRASILIA, BRAZIL}

\subsection{ABSTRACT}

One of the main obstacles to the establishment of mahogany plantations is the occurrence of Hypsipyla grandella Zeller, which attacks the terminal bud in new seedlings and trees, forming galleries. This study aimed to isolate, identify and verify the pathogenic ability of fungi associated with $H$. grandella in Brasilia, Brazil. For this, 200 fruit attacked by insects were collected and analyzed. A caterpillar with fungal infection symptom was found. Symptomatic caterpillar was placed in a humid chamber for increased formation of spores and then pure colonies were obtained from serial dilutions and successive subcultures of the fungus. Its molecular, morphological and pathogenic was made. The isolate was identified as Beauveria bassiana (Balsamo) Vuillemin, an entomopathogen widely used in biological control programs. Pure colonies were white, and the optical microscope showed unicellular conidia, conidiogenous cells with denticles conspicuous, featuring the species. As for the pathogenicity test, the isolated was effective, with $70 \%$ mortality of newly hatched caterpillar. This is the first report of an entomopathogenic fungus found in $H$. grandella the Distrito Federal, Brazil. The isolate was incorporated into the "Coleção de Fungos de Invertebrados" of "Embrapa Recursos Genéticos e Biotecnologia".

Keywords: forest entomology, biological control, entomopathogenic fungus. 


\subsection{INTRODUÇÃO}

O mogno (Swietenia macrophylla King) é uma espécie florestal de elevado valor comercial, sendo considerada como nobre ou "madeira de lei" em muitos países. Sua propagação é feita via sementes e o início da frutificação nas árvores começa aos oito anos de idade (Yared \& Carpanezzi, 1981). Uma árvore adulta pode produzir até 600 frutos ou 30 mil sementes por ano, que são dispersas pelo vento até cerca de 80 metros da árvore matriz, principalmente na direção dos ventos mais fortes e durante o final da estação seca (Gullison $e t$ al., 1996).

O plantio de mogno para florestamento e reflorestamento seria uma alternativa viável tanto, para a recuperação de áreas degradadas, como para o estabelecimento comercial sustentável de madeira. Porém, um dos principais entraves é a ocorrência da broca, Hypsipyla grandella Zeller (Lepidoptera: Pyralidae), que ataca o broto terminal em mudas e árvores novas, formando galerias em seu interior (Grijpma \& Gara, 1976). O crescimento, estabelecimento e formação de um fuste reto e com o menor número de nós possível é comprometido, resultando em árvores com grande bifurcação do fuste, com perdas de até 35\% em altura nos três primeiros anos e morte da planta, após ataques sucessivos (Ohashi et al., 2002). Tentativas do cultivo de mogno fora de sua área de origem foram consideradas um fracasso devido às mudas de baixa qualidade e a incidência de H. grandella (Carvalho, 2007).

Não existe atualmente uma técnica eficaz para o controle da broca do mogno. As medidas usualmente utilizadas em diferentes países e com diferentes graus de sucesso envolvem o manejo silvicultural, com o plantio consorciado de mogno e outras espécies resistentes à $H$. grandella, controle químico e o controle biológico com o uso de inimigos naturais (Lunz et al., 2009).

Os fungos entomopatogênicos têm grande versatilidade e podem infectar diferentes estágios de desenvolvimento dos hospedeiros. Penetram os insetos através do tegumento, por 
via oral, anal, entre outras formas. Os fungos mais utilizados na redução populacional de insetos-praga de florestas são Metarhizium anisopliae (Metsch.) Sorokin e Beauveria bassiana (Balsamo) Vuillemin (Costa et al., 2008). Segundo Alves (1998), os sinais das doenças produzidas por $B$. bassiana em insetos são caracterizados inicialmente pela interrupção da alimentação e desorientação, posteriormente aparecem as hifas através dos espiráculos e, finalmente, pela presença do micélio que envolve externamente o cadáver do inseto, dando o aspecto de algodão, de cor branca.

Devido a sua elevada importância comercial, ecológica e paisagística, o interesse de realizar pesquisas com o objetivo de preservar, conservar e garantir o uso sustentável do mogno é evidente, sendo necessárias pesquisas com o intuito de diminuir os prejuízos causados por essa praga. Esse trabalho teve como objetivo isolar, identificar e verificar a capacidade patogênica de fungos associados à $H$. grandella em Brasília, Brasil.

\subsection{MATERIAL E MÉTODOS}

\subsubsection{Obtenção de lagartas com sintomas}

Foram analisados 200 frutos coletados em Brasília, Distrito Federal, para a verificação da ocorrência, quantificação e isolamento de possíveis agentes fúngicos de biocontrole da $H$. grandella. Os frutos foram abertos e os insetos que apresentaram sintomas e/ou sinais de fungos foram separados e individualizados em recipientes plásticos estéreis e armazenados em geladeira até o seu isolamento.

\subsubsection{Isolamento do fungo entomopatogênico}

Os insetos sintomáticos foram colocados em câmara úmida para maior formação de esporos e então, com o auxílio de um microscópio estereoscópio e uma agulha, parte do fungo 
foi transferido para meio BDA. Colônias puras foram obtidas a partir de diluições seriadas e repicagens sucessivas do fungo.

\subsubsection{Caracterização morfológica}

As estruturas fúngicas foram retiradas do meio de cultura por meio de estilete de ponta fina e em seguidas colocadas sobre lâminas de vidro com corantes à base de lacto-glicerol / azul de algodão (Cotton blue) ou glicerol-KOH / floxina básica, as quais foram seladas com duas camadas de esmalte de unha comercial. Foram descritos e medidos os conidióforos, células conidiogênicas e conídios do fungo por meio de microscópio óptico.

Para a visualização das estruturas fúngicas em microscopia eletrônica de varredura, amostras do fungo foram fixadas com glutaraldeído 2,5\% e tampão cacodilato de sódio a 0,1M pH 7,0 e colocados em rotator orbital (4 rpm) por 24 horas. Após esta etapa, as amostras foram submetidas a duas lavagens de 15 minutos em tampão cacodilato de sódio a $0,1 \mathrm{M}$ pH 7,2, seguidas de imersão em solução de tetróxido de ósmio (OsO4) a 2\% por 2 horas. As amostras pós-fixadas em OsO4 foram lavadas em tampão cacodilato de sódio $0,1 \mathrm{M}$, por 3 vezes seguidas e por mais 2 vezes com água a cada 15 minutos. Foi realizada a desidratação dos materiais em série etanólica crescente (10, duas vezes de 30, 50, 70, 90 e 100\%) permanecendo por 2 horas em cada uma das concentrações, sempre utilizando um rotator orbital. Em seguida, as amostras foram secas pelo método do ponto crítico do $\mathrm{CO} 2$ em aparelho Baltec CPD 030, recobertas com 25 nm de ouro em aparelho MED 010 da Balzers e observadas ao microscópio eletrônico de varredura Zeiss modelo DSM 962.

\subsubsection{Caracterização molecular e sequenciamento}

O isolado purificado foi crescido em meio de cultura BDA, em câmara de germinação (BOD) à $25+\_0.5^{\circ} \mathrm{C}$ por 10 dias. Foram cortados três discos do meio de cultura contendo o 
fungo e inoculados em frasco de Erlenmeyer com 200mL de meio líquido SDY (4\% dextrose, $1 \%$ extrato de levedura e $1 \%$ peptona). Após $72 \mathrm{~h}$ de incubação em shaker rotativo a $25+\_0.5^{\circ} \mathrm{C}$ e $250 \mathrm{rpm}$, o micélio foi coletado em papel de filtro sob filtração a vácuo e utilizado para a extração de DNA segundo o método descrito por Raeder e Broda (1985). A região intergênica Bloc foi amplificada e sequenciada de acordo com Renher et al. (2011). A sequência obtida foi editada pelo programa DNA baser (DNABaser Sequence Assembler 3, Heracle Biosoft, Pitesti, Romania) e alinhada com outras 23 sequencias obtidas pelo banco de dados GenBank, segundo Renher et al. (2011), através do programa MEGA 5.03 (Tamura et al., 2011), utilizando o clustaw. Este alinhamento foi utilizado para a construção de uma árvore filogenética (Figura 2), através do programa Mr Bayes, utilizando as informações geradas pelo critério de Akaike (AIC) através do JModeltest 1.1 e com 1 milhão de gerações.

\subsubsection{Bioensaio de mortalidade}

O isolado obtido foi testado em condições de laboratório quanto a sua patogenicidade em $H$. grandella no Laboratório de Micologia de Invertebrados da Embrapa Recursos Genéticos e Biotecnologia em Brasília, Brasil, em maio de 2015. Para a realização do ensaio, foram utilizados ovos férteis, obtidos a partir da criação do inseto feita com dieta natural a base de sementes de mogno. O experimento foi conduzido em delineamento inteiramente casualizado, com um tratamento e cinco repetições, com 10 ovos por repetição. O tratamento consistiu na inoculação dos ovos na suspensão de conídios com água destilada autoclavada com $0,05 \%$ de Tween 80 . A concentração utilizada foi de $1 \times 10^{8}$ conídios $/ \mathrm{mL}$ além da testemunha com água destilada e Tween 80. Os ovos e lagartas foram observados diariamente durante sete dias, quanto ao parasitismo pelo fungo e mortalidade de lagartas recémeclodidas. Foram colocadas duas folhas novas de mogno esterilizadas para a alimentação das 
lagartas neonatas. Esse bioensaio foi repetido duas vezes para comprovar a ação patogênica do fungo.

As lagartas neonatas mortas foram retiradas dos recipientes, desinfectadas externamente com álcool 70\% e mantidas em câmara úmida para esporulação e confirmação do agente causal da mortalidade.

\subsection{RESULTADOS E DISCUSSÃO}

Apenas cinco lagartas foram encontradas mortas no interior dos frutos, representando $2,78 \%$ do total de lagartas encontradas $(n=180)$. Destas, três apresentaram sintomas de bacteriose, uma de fungo (Figura 1 - A) e outra por causas desconhecidas. A quantidade de lagartas mortas encontradas foi inferior à verificada por Thomazini et al. (2011) quando coletaram lagartas no broto terminal de árvores de mogno, chegando a nove em um total de 28 coletadas no mês de maio de 2010 em Garça/SP. A mortalidade larval natural foi de 14,8\% em todo o estudo. Já em um trabalho realizado por Taveras et al. (2004), na Costa Rica, a taxa de mortalidade foi de $24 \%$. A baixa taxa de mortalidade dos insetos no presente estudo pode ser atribuída ao fato do inseto estar protegido de possíveis predadores e de contaminação por fungo e bactérias. $\mathrm{O}$ fato de o estudo ser realizado em árvores urbanas também pode influenciar a mortalidade, visto que na cidade há menor número de inimigos naturais quando comparada ao ambiente natural.

O fungo isolado da lagarta em meio BDA foi identificado como Beauveria bassiana, com colônias brancas a ligeiramente amareladas de aspecto cotonoso e pulverulento, características do gênero Beauveria (De Hoog, 1972; McCoy et al., 1988) (Figura 1 - B e C). A análise das estruturas fúngicas em microscopia óptica e em microscopia eletrônica de varredura mostrou conídios de forma globosa a subglobosa, asseptados, lisos, numerosos, com germinação uni ou bipolar (Figura 1 - D, E e F). Os conidióforos formam cachos densos, 
com células conidiogênicas em zigue-zague. O isolado foi depositado na Coleção de Fungos Entomopatogênicos da Embrapa Recursos Genéticos e Biotecnologia (CG 1301 / BRM 029000).
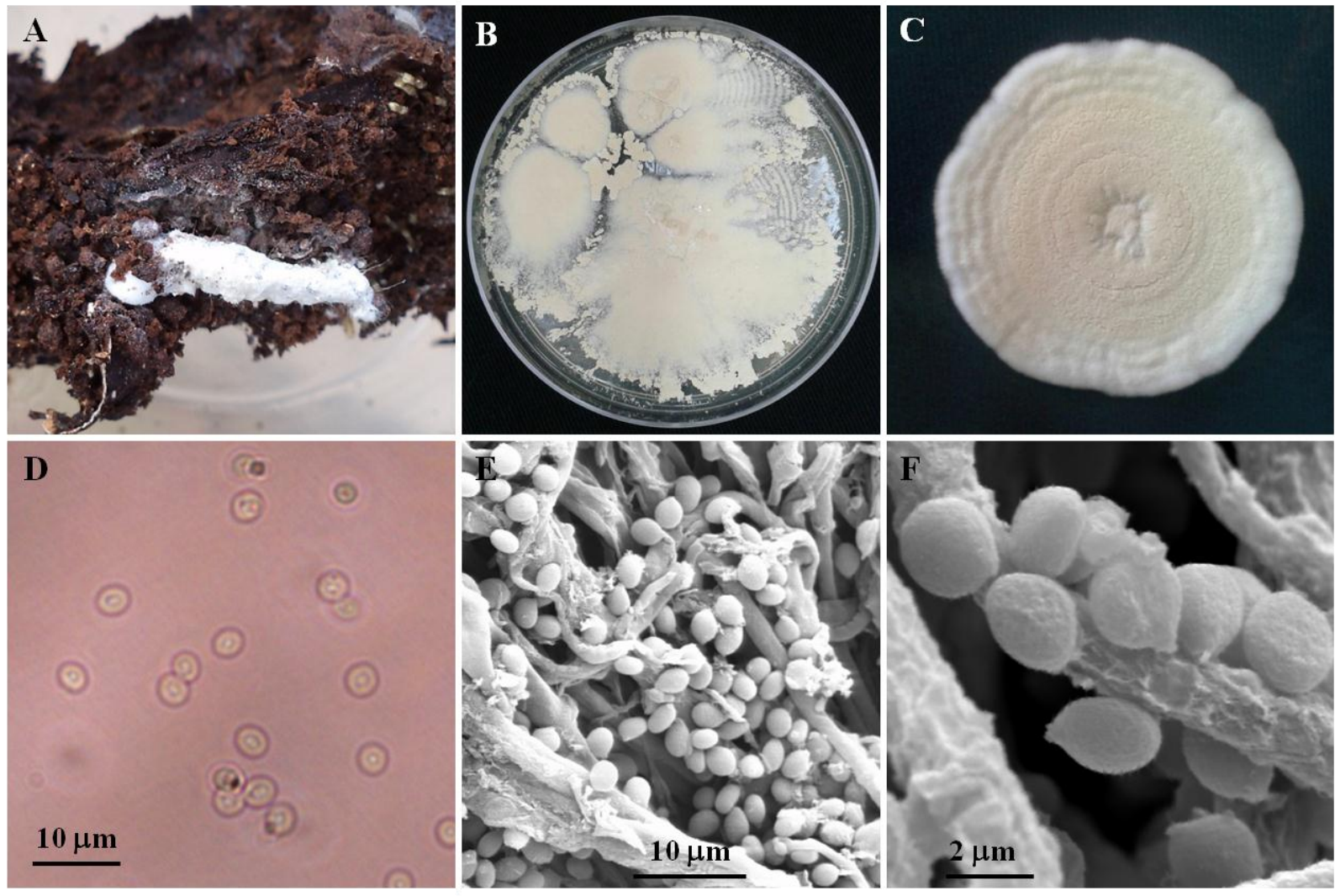

Figura 1 (A - F). Beauveria bassiana isolada de Hypsipyla grandella. A - Lagarta com sintomas de infecção fúngica. B - Cultura de B. bassiana em meio BDA. C - Detalhe da cultura monospórica em meio BDA, após dez dias de crescimento. D - Conídios de $B$. bassiana vistos em Microscópio de Luz. E e F - Detalhe dos conídios do fungo vistos em Microscopia Eletrônica de Varredura.

A análise filogenética do isolado (CG1301) o identificou como Beauveria bassiana com grande suporte através da inferência bayesiana (Figura 2), agrupando-o com os outros dois isolados de referência de B. bassiana. 


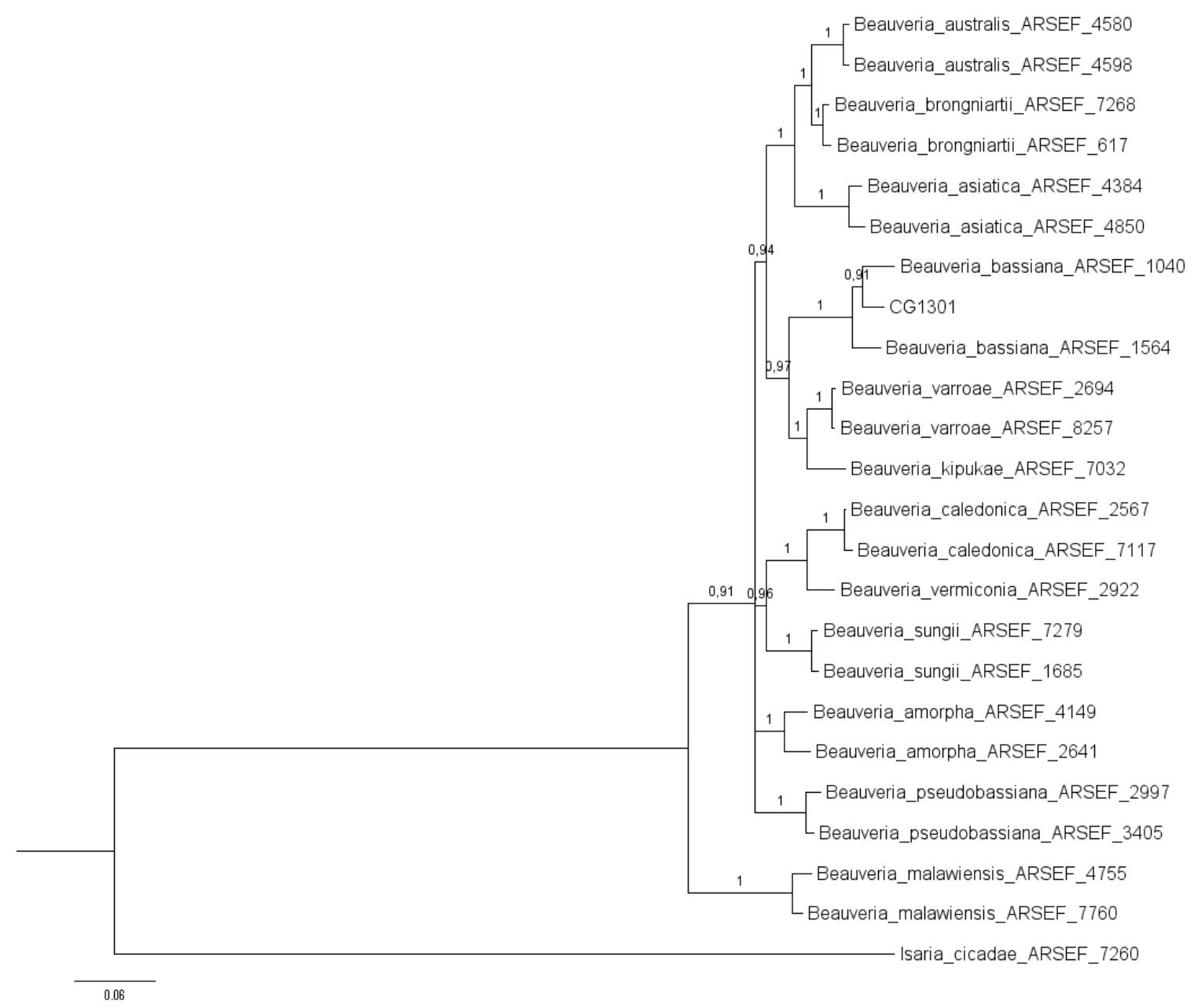

Figura 2. Árvore filogenética dos isolados do gênero Beauveria através da análise Bayesiana da região intergênica Bloc. Os valores de suporte da inferência Bayesiana são mostrados na árvore.

Quanto ao bioensaio de mortalidade, as largartas eclodiram após 24 horas da inoculação do fungo. Após sete dias, todos os ovos da testemunha se mostraram viáveis, ao passo que cinco ovos (10\%) com o tratamento com B. bassiana não resultaram em lagartas. Porém, 30 (trinta) lagartas recém-eclodidas do tratamento com o fungo morreram após sete dias $(70 \%)$, o que indica que o isolado obtido pode ser promissor para ser utilizado futuramente em programas de controle da $H$. grandella. 
Yamazaki et al. (1990) reportaram um isolado de Beuveria não identificado infectando H. grandella no Peru, com baixa mortalidade. Misra (1993) isolou B. bassiana em cadáveres de H. robusta na Índia e constatou $80 \%$ de mortalidade de lagartas quando inoculadas com esporos obtidos da cultura pura do fungo em água. Berrios \& Hidalgo-Salvatierra (1973) testaram a patogenicidade de esporos de $B$. bassiana em $H$. grandella. As lagartas foram imersas em uma suspensão de esporos e apresentaram mortalidade de 13,9\% sob uma concentração de $1,4 \times 10^{6}$ esporos $/ \mathrm{mL}$. Segundo os autores, a maioria das lagartas morreram oito dias após a inoculação do fungo.

\subsection{CONCLUSÕES}

- O fungo Beauveria bassiana foi encontrado em Hypsipyla grandella;

- Sua patogenicidade foi testada e comprovada, com mortalidade de aproximadamente $70 \%$ de lagartas recém-eclodidas.

\subsection{REFERÊNCIAS BIBLIOGRÁFICAS}

ALVES, S.B. 1998. Fungos entomopatogênicos. In: ALVES, S. B (Ed.). Controle microbiano de insetos. 2. Ed. Piracicaba: FEALQ, p. 289-382.

BERRIOS, F.; HIDALGO-SALVATIERRA, O. 1973. Susceptibility of the larva to the fungi Beauveria bassiana (Bal.) and B. tenella (Del.). In: GRIJPMA, P. (Ed.) Studies on the shoot borer Hypsipyla grandella (Zeller) Lepidoptera: Pyralidae, Turrialba, v. 24, n. 4, p. 68-70.

CARVALHO, P. E. R. 2007. Mogno - Swietenia macrophylla. Colombo, Paraná, Embrapa Florestas. Circular Técnico 140, p. 12. 
COSTA, E. C.; D’AVILlA, M.; CANTARELli, E. D.; MURARI, A. B.; MANZONI, C. G. 2008. Entomologia Florestal. Santa Maria: Editora UFSM, 239 p.

DE HOOG, G. S. 1972. The genera Beauveria, Isaria, Tritirachium and Acrodontium gen. nov. Studies in Mycology, v. 1, p. 1-41.

GULLISON, R. E.; PANFIL, S. N.; STRUOSE, J. J.; HUBBELL, S. P. 1996. Ecology and management of mahogany (Swietenia macrophylla King) in the Chimanes Forest, Neni, Bolivia. Botanical Journal of the Linnean Society, v. 122, p. 9-34.

GRIJPMA, P.; GARA, R. I. 1976. Studies on the shootborer Hypsipyla grandella (Zeller): II. Host preference of the larva. Turrialba, v. 20, p. 241-247.

LUNZ, A. M; THOMAZINI, M. J.; MORAES, M. C. B.; NEVES, E. J. M.; BATISTA, T. F. C.; DEGENHARDT, J.; SOUSA, L. A.; OHASHI, O. S. 2009. Hypsipyla grandella em Mogno (Swietenia macrophylla): situação atual e perspectivas. Pesquisa Florestal Brasileira, n. 59, p. 45-55.

MCCOY, C.W.; SAMSON, R. A.; BOUCIAS, D.G. 1988. Entomogenous fungi. In: Ignoffo, C.M. ed. Handbook of Natural Pesticides, v. V. CRC Press, p. 151-237.

MISRA, R.M. 1993. Beauveria bassiana (Balsamo) Vuillemin, a fungal pathogen of Hypsipyla robusta Moore (Lepidoptera: Pyralidae). Indian Journal of Forestry, v. 16, p. $236-238$. 
OHASHI, S. T.; SILVA, J. N. M.; SILVA, M. E. C. E.; COSTA, M. S. S.; SARMENTO JUNIOR, R. G.; SANTOS, E. B.; ALVES, M. Z. N.; PESSOA, A. M. C.; SILVA, T. C. O.; BITTENCOURT, P. R. G.; BARBOSA, T. C.; SANTOS, T. M. 2002. Manejo Integrado da Broca do Mogno Hypsipyla grandella Zeller (Lep. Pyralidae). In: POLTRONIERI, L. S.; TRINDADE, D. R. Manejo integrado das principais pragas e doenças de cultivos amazônicos. Belém: Embrapa Amazônia Oriental, 304 p.

READER, U. E.; BRODA, P. RAPD preparation of DNA from filamentous fungi. Letters in Applied Microbiology, v. 1, p.17-20, 1985. http://dx.doi.org/10.1111/j.1472-765X.1985. tb01479.x

RENHER, M.; DOMANOV, Y.; SANDRIN, F.; IZEDDIN, I.; BASSEREAU, P.; TRILLER, A. 2011. Lateral diffusion on tubular membranes: quantification of measurements bias. PLoS ONE, v. 6:e25731.

TAMURA, K.; BATTISTUZZI, F. U.; BILLING-ROSS, P.; MURILLO, O.; FILIPSKI, A.; KUMAR, S. 2011. Estimating divergence times in large molecular phylogenies. Proceedings of the National Academy of Sciences, v. 109, n. 47, p. 19333-19338.

TAVERAS, R.; HILJE, L.; CARBALLO, M. 2004. Development of Hypsipyla grandella (Zeller) (Lepidoptera: Pyralidae) in response to constant temperatures. Neotropical Entomology, n. 33, p. 1-6. 
THOMAZINI, M. J.; TEDESCHI, V. H. P.; MEIRA, J. R. DE. 2011. Incidência e danos da broca-das-meliáceas, Hypsipyla grandella, em mogno, no interior paulista. Colombo: Embrapa Florestas, Comunicado Técnico, n. 280, 6 p.

YAMAZAKI, S.; TAKETANI, A.; FUJITA, K.; VASQUES, C.; IKEDA, T. 1990. Ecology of Hypsipyla grandella and its seasonal changes in population density in Peruvian Amazon forest. Japan Agricultural Research Quarterly, v. 24, p. 149-155.

YARED, J. A. G.; CARPANEZZI, A. A. 1981. Conversão de capoeira alta da Amazônia em povoamento de produção madeireira: o método "recrû" e espécies promissoras. Belém: EMBRAPA CPATU, 27 p. 


\section{CAPÍTULO 4}

\section{CONTROLE BIOLÓGICO DE Hypsipyla grandella Zeller (Lepidoptera: Pyralidae) COM Bacillus thuringiensis Berliner EM LABORATÓRIO}

\subsection{RESUMO}

O uso de Bacillus thuringiensis (Bt) para o controle de insetos-praga já está estabelecido em várias culturas agronômicas e florestais, por ser uma bactéria que não possui efeito poluente ao meio ambiente, inocuidade aos mamíferos e vertebrados, ausência de toxicidade às plantas e especificidade aos insetos alvo. Até o presente momento não foram realizados estudos aprofundados quanto ao uso de Bt para o controle da principal praga do mogno, a Hypsipyla grandella (Lepidoptera: Pyralidae). Portanto, esse trabalho teve como objetivo testar a patogenicidade de estirpes de $B t$ em lagartas de $H$. grandella, assim como determinar a concentração letal para matar $50 \%$ da população $\left(\mathrm{CL}_{50}\right)$ das estirpes mais promissoras e de suas principais toxinas. Para tanto, foram utilizadas dez estirpes de $B t$ comprovadamente tóxicas a lepidópteros em ensaios anteriores e estas foram incorporadas em dieta natural com sementes de mogno para verificar a sua mortalidade. $\mathrm{A} \mathrm{CL}_{50}$ das cinco melhores estirpes foi determinada, assim como de cinco proteínas Cry comuns em várias dessas estirpes. Os resultados comprovaram que $H$. grandella é altamente suscetível às toxinas de $B t$ e que a estirpe S1905 é altamente tóxica. Além disso, parece haver sinergismo entre as toxinas Cry. Portanto, o uso de estirpes de $B t$ pode ser uma ferramenta para ser incorporada no manejo integrado dessa importante praga das meliáceas.

Palavras-chave: bioensaios, Bt, proteínas Cry, toxinas Cry, broca do mogno. 


\section{BIOLOGICAL CONTROL OF Hypsipyla grandella Zeller (Lepidoptera: Pyralidae) WITH Bacillus thuringiensis Berliner IN LABORATORY}

\subsection{ABSTRACT}

The use of Bacillus thuringiensis (Bt) to control insect pests is already established in various agronomic and forest crops, being a bacterium that has no polluting effect on the environment, safety to mammals and vertebrates, lack of toxicity to plants and specifity to target insects. To date it has not been conducted in-depth studies about the use of $B t$ to control the main pest of mahogany, the Hypsipyla grandella (Lepidoptera: Pyralidae). Therefore, this study aimed to test the pathogenicity of $B t$ strains on $H$. grandella caterpillars, as well determine the lethal concentration to kill $50 \%$ of the population $\left(\mathrm{LC}_{50}\right)$ of the most promising strains and it main toxins. To this, was used ten strains of $B t$ toxic to lepidopteran proven in previus trials and these were incorpored into natural diet with mahogany seeds to check their mortality. The $\mathrm{LC}_{50}$ of the top five strains was determined, and five Cry proteins comoon in several of these strains. The results prove that $H$. grandella is highly susceptible to $B t$ toxins and the S1905 strain is highly toxic. In addition, there appears to be synergy between the Cry toxins. Therefore, the use of $B t$ strains may be a tool to be incorporated into the integrated management of this important pest of mahogany.

Keywords: bioassays, Bt, cry proteins, cry toxins, mahogany shoot borer. 


\subsection{INTRODUÇÃO}

Um dos principais problemas da silvicultura do mogno brasileiro, Swietenia macrophylla King, é ocorrência da Hypsipyla grandella Zeller, na qual ataca os brotos terminais das plantas, inviabilizando o cultivo comercial dessa espécie. O controle dessa praga é dificultado devido ao seu hábito críptico e inviabilidade de aplicação de defensivos químicos a grandes alturas. O uso de Bacillus thuringensis Berliner (Bt) pode ser uma alternativa viável e econômica para esse fim. Bt é uma bactéria gram positiva, aeróbia, da família Bacillaceae, de abrangência cosmopolita (Krywunczyk \& Fast, 1980) e que possui atividade inseticida. A ação entomopatogênica dessa bactéria se deve justamente a inclusões protéicas que são cristais compostos por proteínas denominadas endoproteínas ou proteínas cristal (Bravo et al., 1998; Monnerat \& Bravo, 2000).

$\mathrm{O}$ uso de $B t$ no biocontrole de insetos-praga apresenta muitas vantagens como a sua especificidade aos insetos alvo, possui efeito não poluente ao meio ambiente, inocuidade aos mamíferos e vertebrados e ausência de toxicidade às plantas, o que permite a sua aplicação direta (Whiteley \& Schnepf, 1986). Segundo Quesada-Moraga et al. (2004), esse organismo tem merecido atenção pelos pesquisadores por controlar larvas/lagartas/ninfas de insetos das ordens Lepidoptera, Diptera, Coleoptera, Orthoptera e Hemiptera, além de outros organismos, como ácaros, nematoides e protozoários. São poucas as pesquisas relacionadas ao uso de $B t$ para o controle de $H$. grandella. Em uma revisão feita por Lunz et al. (2009), o uso de Bt na cultura do mogno está restrita a aplicação antes da penetração das lagartas nos ramos (Gallo et al., 2002).

Portanto, esse trabalho teve como objetivo testar a patogenicidade de estirpes de $B t \mathrm{em}$ lagartas de $H$. grandella, assim como determinar a $\mathrm{CL}_{50}$ das estirpes mais promissoras e de algumas toxinas Cry. 


\subsection{MATERIAL E MÉTODOS}

\subsubsection{Estirpes utilizadas}

Foram utilizadas dez estirpes de B. thuringiensis (Tabela 1) escolhidas com base em bioensaios de mortalidade para insetos da ordem Lepidoptera realizados por Praça (2012) e Macedo et al. (2012).

Tabela 1. Estirpes de Bacillus thuringiensis utilizadas nos bioensaios seletivos.

\begin{tabular}{ccc}
\hline Estirpe & Toxinas & Fonte \\
\hline S602 & Cry 1Aa, Cry 1Ab, Cry 1Ac, Cry 2Aa, Cry 2Ab & Macedo et al. (2012) \\
S1264 & Cry 1Aa, Cry 1Ab, Cry 1Ac, Cry2Aa & Macedo et al. (2012) \\
S1289 & Cry 1Ab, Cry 1Ad, Cry 2Ab & Macedo et al. (2012) \\
S1301 & Cry 1Ab, Cry 1F, Cry 1Ac, Cry 1D, Cry 1G, Cry 2Aa, Cry 2Ab & Macedo et al. (2012) \\
S1905 & Cry 1Aa, Cry 1Ab, Cry 1Ac, Cry 1B, Cry 2Aa, Cry 2Ab & Praça (2012) \\
S1979 & Cry 1Aa, Cry 1Ab, Cry 1Ac, Cry 1Ad, Cry 2Aa, Cry 2Ab & Macedo et al. (2012) \\
S2021 & Cry 1Aa, Cry 1Ad, Cry 2Ab & Macedo et al. (2012) \\
S2122 & Cry 1Aa, Cry 1Ab, Cry 1Ad, Cry 1C, Cry 1D, Cry 1F, Cry 2Ab & Praça (2012) \\
S2124 & Cry 1Ab, Cry 1E, Cry 2Aa, Cry 2Ab & Praça (2012) \\
Btk 1450 HD-1 & Cry 1Aa, Cry 1Ab, Cry 1Ac, Cry 1B, Cry 2Aa, Cry 2Ab & Praça (2012) \\
\hline
\end{tabular}

\subsubsection{Produção das bactérias e montagem do bioensaio seletivo}

O bioensaio seletivo foi realizado com base em protocolos para outras espécies de Lepidoptera (Praça et al., 2004), com modificações. As estirpes listadas (Tabela 1) foram fermentadas em meio Embrapa (Monnerat et al., 2007) empregando-se incubador rotativo a $200 \mathrm{rpm}, 28^{\circ} \mathrm{C}$, durante 72 horas, até a obetenção de esporos. As estirpes foram visualizadas em microscópio óptico de contraste de fases com aumento de 1.000 x para observação de esporos e cristais. O caldo bacteriano $(100 \mu \mathrm{L})$ foi misturado com sementes de mogno trituradas em uma placa de Petri estéril e foram oferecidas a dez lagartas neonatas $\left(1^{\circ}\right.$ instar) por placa, com três repetições. A testemunha negativa consistiu da dieta misturada com água 
destilada. O material foi acomodado em B.O.D. com fotoperíodo de 12 horas e com 24 a 27 ${ }^{\circ} \mathrm{C}$.

A avaliação da mortalidade ocorreu após 24 e 48 horas e as lagartas vivas foram transferidas para outra placa contendo sementes trituradas sem tratamento. A última leitura de mortalidade foi feita após 96 horas.

\subsection{3 $\mathrm{CL}_{50}$ das melhores estirpes e de toxinas Cry puras}

As melhores estirpes (S1905, S2021, S2122, S2124, Btk 1450 HD-1) foram utilizadas para o cálculo da $\mathrm{CL}_{50}$. Para cada estirpe multiplicada foram realizadas centrifugações a 9.500 por 30 minutos (Centrífuga Hettich Zentrifugen, modelo Rotanda 460R), o sobrenadante foi desprezado para obtenção de um pellet concentrado ao final do trabalho e posteriormente foi ressuspendido em água destilada, congelado e depois liofilizado em Liofilizador Christ, modelo Alpha 2-4 LD Plus. O material liofilizado foi acondicionado em tubos Falcon e armazenado à $-20^{\circ} \mathrm{C}$.

Foi feita a contagem de esporos de todas as estirpes utilizadas através da determinação do número de unidades formadoras de colônia por $\mathrm{mL}(\mathrm{UFC} / \mathrm{mL})$, a partir de diluições em série. Para tanto, em $5 \mathrm{~mL}$ de água destilada autoclavada foram diluídos 0,005 g da biomassa liofilizada contendo esporo-cristal (diluição $10^{-1}$ ). A diluição $10^{-1}$ foi homogeneizada em vórtex, e para a composição da diluição $10^{-2}$, foram acrescentadas $4,5 \mathrm{~mL}$ de água destilada autoclavada e $0,5 \mathrm{~mL}$ da diluição anterior e assim sucessivamente. Todas as diluições foram plaqueadas em triplicata em placas de Petri contendo meio Embrapa Ágar (Monnerat et al., 2007) e foi utilizada a técnica da gota. Para cada replicata foram plaqueados $10 \mu 1$ da diluição correspondente com o auxílio de uma pipeta. As placas foram vedadas com filme PVC, de forma que o meio de cultura estivesse voltado para cima, e foram incubadas em estufa a $28{ }^{\circ} \mathrm{C}$ por aproximadamente 15 horas, para posterior contagem das UFC's. 
As estirpes recombinantes S2211 (Cry 1Aa), S2210 (Cry 1Ab), S2209 (Cry 1Ac) e S2212 (Cry 2Aa) foram utilizadas para o cálculo da $\mathrm{CL}_{50}$ das toxinas puras. As estirpes foram crescidas em meio EMBRAPA, conforme descrito anteriormente, porém com o uso de antibiótico $(10 \mu \mathrm{g} / \mathrm{mL}$ de eritromicina). Posteriormente o cultivo foi centrifugado por 10 minutos a $10.000 \mathrm{rpm}$ com temperatura de $4{ }^{\circ} \mathrm{C}$, com tampão contendo $0,3 \mathrm{M}$ de $\mathrm{NaCl}$ e 0,01 $\mathrm{M}$ de EDTA (pH 8,0), e em seguida por três vezes com o tampão PMFS a 1mM. O sobrenadante foi recuperado e o sedimento recuperado com tampão TTN (20 mM de tris, 300 $\mathrm{mM}$ de $\mathrm{NaCl}, 0,1 \%$ de triton $\mathrm{x}-100, \mathrm{pH} 7,2)$, posteriormente centrifugado a $10.000 \mathrm{rpm} \mathrm{e} 4{ }^{\circ} \mathrm{C}$ durante 10 minutos, e repetido por três vezes. O material foi então sonicado a três pulsos de um minuto com intervalos iguais de um minuto a $15 \mathrm{~W}$ (VirSonic CelDisrutter 16-850). As estirpes recombinantes foram purificadas por meio de gradiente de sacarose (Thomas \& Ellar, 1983), recuperadas com a adição de triton 1\% (v/v) e PMSF 1 mM e solubilizadas em tampão alcalino decarbonato de sódio a $50 \mathrm{mM}$ e pH 10,5 com $0,2 \%$ (v/v) de $\beta$-mercaptoetanol por duas horas a $37{ }^{\circ} \mathrm{C}$ com agitação constante de $60 \mathrm{rpm}$. A amostra foi então centrifugada por 5 minutos a 12.000 x g e em seguida a proteína solúvel foi quantificada com Protein Assay (Bio Rad) pelo método de Bradford (Bradford, 1976). A observação da integridade e massa molecular das proteínas foi feita a partir de um gel desnaturante de polacrilamida (SDSPAGE) a 12\% (Laemmli, 1970), corado com Comassie blue (40\% metanol, ácido acético 10\% e Comassie blue $0,1 \%$ ) por aproximadamente 16 horas sob leve agitação e descorado com 20 mL de água por 1-2 horas até a visualização dos perfis proteicos das estirpes.

O cálculo da concentração letal para matar $50 \%$ dos indivíduos $\left(\mathrm{CL}_{50}\right)$ foi determinado a partir de quatro diluições seriadas do liofilizado das três estirpes selecionadas, na qual foram colocadas em sementes de mogno trituradas. Para cada diluição foram utilizadas 10 lagartas neonatas $\left(1^{\circ}\right.$ instar $)$, com três repetições. A testemunha negativa consistiu da dieta misturada com água destilada. A avaliação da mortalidade ocorreu após 24 e 48 horas e as lagartas vivas 
foram transferidas para outra placa contendo sementes trituradas sem tratamento. Para tanto, primeiramente foi preparada uma solução mãe com $0,5 \mathrm{mg}$ do liofilizado bacteriano mais 5 mL de água destilada autoclavada. A partir da solução mãe, as diluições seriadas foram feitas retirando 0,5 mL da solução e colocadas em 4,5 mL de água destilada autoclavada, e assim sucessivamente, até chegar à diluição de $10^{-9}$. As concentrações utilizadas nos bioensaios foram de 2.000, 432, 93 e $20 \mathrm{ng} / \mathrm{cm}^{2}$

A $\mathrm{CL}_{50}$ foi feita a partir da análise de Probit (Finney, 1971), com o auxílio do programa Polo-Plus®. Os intervalos de confiança (95\%) para a $\mathrm{CL}_{50}$ foram calculados e a não sobreposição desse parâmetro foi utilizada para detectar diferenças significativas entre as estirpes e as proteínas.

\subsection{RESULTADOS E DISCUSSÃO}

Todas as 10 estirpes utilizadas se mostraram altamente letais para $H$. grandella (Tabela 2). A partir desse bioensaio, cinco estirpes foram selecionadas para os ensaios subsequentes. Foi considerada estirpe eficaz aquela que apresentou mortalidade superior a $90 \%$.

As lagartas mortas nos bioensaios apresentaram corpos flácidos e tegumentos de coloração marrom a marrom-escura, com aspecto opaco. Algumas lagartas estavam lentas e com dificuldade para se movimentar, sintomas característicos de infecção por $B t$ (Habib \& Andrade, 1998; Viana et al., 2009; Praça, 2012). Uma observação importante está relacionada ao tempo inicial do potencial de mortalidade, na qual as estirpes 2124, 1905 e 1450 foram superiores aos outros tratamentos. 
Tabela 2. Mortalidade de lagartas de Hypsipyla grandella por estirpes de Bacillus thuringiensis após 24, 48 e 96 horas.

\begin{tabular}{cccc}
\hline \multirow{2}{*}{ Estirpe } & \multicolumn{3}{c}{ Mortalidade } \\
\cline { 2 - 4 } & $24 \mathrm{~h}$ & $48 \mathrm{~h}$ & $96 \mathrm{~h}$ \\
\hline $\mathrm{S} 602$ & $80 \%$ & $86,6 \%$ & $86,6 \%$ \\
$\mathrm{~S} 1264$ & $70 \%$ & $76,6 \%$ & $76,6 \%$ \\
$\mathrm{~S} 1289$ & $60 \%$ & $63,3 \%$ & $70 \%$ \\
$\mathrm{~S} 1301$ & $73,3 \%$ & $80 \%$ & $80 \%$ \\
$\mathrm{~S} 1905$ & $93,3 \%$ & $100 \%$ & - \\
$\mathrm{S} 1979$ & $60 \%$ & $60 \%$ & $66,6 \%$ \\
$\mathrm{~S} 2021$ & $83,3 \%$ & $86,6 \%$ & $100 \%$ \\
$\mathrm{~S} 2122$ & $90 \%$ & $100 \%$ & - \\
$\mathrm{S} 2124$ & $86,6 \%$ & $100 \%$ & - \\
Btk $1450 \mathrm{HD}-$ & $100 \%$ & $100 \%$ & - \\
Testemunha & $6,66 \%$ & $10 \%$ & $16,6 \%$ \\
\hline
\end{tabular}

A $\mathrm{CL}_{50}$ das melhores estirpes (S1905, S2021, S2122, S2124 e a padrão Btk 1450 HD1) variou entre 9,55 e $85,61 \mathrm{ng} / \mathrm{cm}^{2}$ (Tabela 3). A estirpe padrão Btk $1450 \mathrm{HD}-1$ foi a que apresentou a menor concentração $\left(9,55 \mathrm{ng} / \mathrm{cm}^{2}\right)$, enquanto a estirpe $\mathrm{S} 2021$ apresentou a maior $\left(85,61 \mathrm{ng} / \mathrm{cm}^{2}\right)$. Porém, elas não diferiram estatisticamente porque os intervalos de confiança se sobrepõem, o que indica que todas as estirpes são igualmente eficientes no controle de $H$. grandella.

Tabela 3. Concentração letal $\left(\mathrm{CL}_{50}\right)$ das estirpes de Bacillus thuringiensis para matar lagartas de Hypsipyla grandella da população testada após cinco dias de tratamento (96 horas).

\begin{tabular}{ccc}
\hline Estirpe & $\mathrm{CL}_{50}\left(\mathrm{ng} / \mathrm{cm}^{2}\right)^{*}$ & Intervalo de Confiança (95\%) \\
\hline $\mathrm{S} 1905$ & $12,715 \mathrm{a}$ & $0,452-40,318$ \\
$\mathrm{~S} 2021$ & $85,617 \mathrm{a}$ & $11,731-244,778$ \\
$\mathrm{~S} 2122$ & $20,573 \mathrm{a}$ & $0,197-74,360$ \\
$\mathrm{~S} 2124$ & $27,520 \mathrm{a}$ & $1,016-87,713$ \\
Btk $1450 \mathrm{HD}-1$ & $9,554 \mathrm{a}$ & $0,097-36,167$
\end{tabular}

*Médias seguidas pelas mesmas letras não diferem entre si pelo intervalo de confiança de acordo com a análise de Probit. 
A susceptibilidade de lagartas de primeiro instar de $H$. grandella ao $B t$ já foi mostrada por Hidalgo-Salvatierra \& Palm (1973), na qual os autores obtiveram até $100 \%$ de mortalidade utilizando diferentes diluições de uma única estirpe bacteriana, comprovando que o inseto é altamente suscetível à bactéria, corroborando os resultados do presente trabalho. No entando, a $\mathrm{CL}_{50}$ da estirpe utilizada não foi estimada. Goulet et al. (2005) utilizaram o produto DiPel 6.4 WG (B. thuringiensis var. kurstaki 6.4\%, ABBOTT Laboratories, Chicago) na forma de spray para o controle da $H$. grandella em plantações Swietenia humilis Zucc. e apenas $17 \%$ das árvores foram atacadas, contra $44 \%$ das plantas controle sem a bactéria.

Todas as quatro estirpes recombinantes de $B$. thuringiensis que expressam as toxinas Cry1Aa, Cry $1 \mathrm{Ab}$, Cry $1 \mathrm{Ac}$ e Cry $2 \mathrm{Aa}$ causaram mortalidade em lagartas de $H$. grandella. Porém, a $\mathrm{CL}_{50}$ das proteínas variou entre 99,83 e 395,48 ng/ $\mathrm{cm}^{2}$ (Tabela 4), apresentando valores de toxicidade signficamente semelhantes, pois os valores do intervalo de confiança se sobrepõem.

Tabela 4. Concentração letal $\left(\mathrm{CL}_{50}\right)$ observada de toxinas puras para matar lagartas de Hypsipyla grandella da população testada após cinco dias de tratamento (96 horas).

\begin{tabular}{ccc}
\hline Toxina & CL $_{50}\left(\mathrm{ng} / \mathrm{cm}^{2}\right)^{*}$ & Intervalo de Confiança $(95 \%)$ \\
\hline Cry 1Aa & $395.484 \mathrm{a}$ & $105,523-2025,488$ \\
Cry $1 \mathrm{Ab}$ & $99,834 \mathrm{a}$ & $12,057-312,299$ \\
Cry 1Ac & $160,661 \mathrm{a}$ & $17,870-645,980$ \\
Cry 2Aa & $112,014 \mathrm{a}$ & $16,019-346,298$
\end{tabular}

*Médias seguidas pelas mesmas letras não diferem entre si pelo intervalo de confiança de acordo com a análise de Probit.

A estimativa da $\mathrm{CL}_{50}$ de proteínas purificadas de B. thuringiensis é realizada para assegurar que o resultado expresse a atividade somente para determinadas toxinas Cry, evitando a influência de outras toxinas, como VIP's e exotoxinas (Aranda et al., 1996; Bohorova et al, 1997). As subespécies aizawai, kurstaki e gallerie normalmente apresentam 
as toxinas Cry $1 \mathrm{Aa}$, Cry $1 \mathrm{Ab}$, Cry $1 \mathrm{Ac}$, Cry 2Aa e Cry 2Ab, toxinas essas que são comprovadamente tóxicas a insetos da ordem Lepidoptera (Kwa et al., 1998; Monnerat et al., 1999; Ibargutxi et al., 2006; Pigott \& Ellar, 2007).

As estirpes Btk $1450 \mathrm{HD}-1$ e S1905 apresentam todas as toxinas puras testadas nos bioensaios e tiveram resultados semelhantes de $\mathrm{CL}_{50}\left(9,55\right.$ e $12,71 \mathrm{ng} / \mathrm{cm}^{2}$, respectivamente), apesar da 1450 ser numericamente mais tóxica. Porém, os resultados das toxinas Cry puras revelaram que possivelmente há sinergismo entre essas elas, ou seja, o poder de controle das estirpes utilizadas nos ensaios depende da composição conjunta de proteínas Cry, corroborando os estudos de Estruch et al. (1997), onde os autores afirmam que o espectro de ação de diferentes isolados de B. thuringiensis depende da combinação das proteínas Cry individuais. Portanto, bioensaios com misturas de toxinas em diferentes proporções devem ser realizados com o propósito de se obter a $\mathrm{CL}_{50}$ observada e então calcular a $\mathrm{CL}_{50}$ esperada, obtendo, assim o Fator de Sinergismo (FS) para verificar se há efeito aditivo, sinergético ou até mesmo antagônico com essas misturas (Tabashnik, 1992).

Além disso, ensaios de ligação e de competição das proteínas Cry aos receptores de membranas instestinais (BBMV's) devem ser realizados com o objetivo de determinar quais proteínas se ligam ao intestin médio do inseto, o que pode indicar quais proteínas estão causando a formação de poros e consequentemente a morte das lagartas. Já o de competição analisa se as proteínas competem por um mesmo sítio de infecção (Aranda et al., 1996). Esses estudos serão importantes para elucidar o patossistema Bacillus thuringensis - Hypsipyla grandella.

Vale lembrar que ocorrem variações de susceptibilidade dos insetos a diferentes toxinas Cry de B. thuringiensis entre espécies e até mesmo populações diferentes, conferindo diferentes graus de toxicidade, como foi demonstrado por Sebastião et al. (2015) em Helicoverpa armigera Hubner (Lepidoptera: Noctuidae), em Spodoptera frugiperda Smith 
(Lepidoptera: Noctuidae) por Monnerat et al. (2006) e em Spodoptera spp por Constanski et al. (2015).

\subsection{CONCLUSÃO}

- H. grandella é altamente suscetível às estirpes S1905, S2021, S2122, S2124 e a padrão Btk 1450 HD-1 de B. thuringiensis.

\subsection{REFERÊNCIAS BIBLIOGRÁFICAS}

ARANDA, E.; SANCHES, J.; PEFEROEN, N.; GUERECA, L.; BRAVO, A. 1996. Interactions of Bacillus thuringiensis crystal proteins with the midgut epithelial cells of Spodoptera frugiperda (Lepidoptera: Noctuidae). Journal of Invertebrate Pathology, v. 68, p. 202-212.

BOHOROVA, N.; CABRERA, M.; ABARCA, C.; QUINTERO, R.; MACIAL, A. M.; BRITO, R. M.; HOISINGTON, D.; BRAVO, A. 1997. Susceptibility of four tropical lepidopteran maize pests to Bacillus thuringiensis CryI-type inseticidal toxins. Journal of Economic Entomology, v. 90, p. 412-415.

BRADFORD, M. 1976. A rapid and sensitive method for the quantitation of microgram quantities protein utilizing the principle of protein dye biding. Analytical Biochemistry, v. 72, p. 248-254.

BRAVO, A.; SARABIA, S.; LOPEZ, L.; ONTIVEROS, H.; ABARCA, C.; ORTIZ, A.; ORTIZ, M.; LINA, L.; VILLA-LOBOS, F.J.; GUADALUPE, P.NUNEZ-VALDEZ, M.E.; SOBERÓN, M.; QUINTERO, R. 1998. Characterization of cry genes in Mexican Bacillus 
thuringiensis strain collection. Applied Environmental Microbiology, v. 64, n.12, p. 49654972.

CONSTANSKI, K. C.; ZORZETII, J.; VILAS BOAS, G. T.; RICIETO, A. P. S.; FAZION, F. A. P.; VILAS BOAS, L. V.; MONNERAT, R. G.; NEVES, P. M. O. J. 2015. Seleção e caracterização molecular de isolados de Bacillus thuringiensis para o controle de Spodoptera spp. Pesquisa Agropecuária Brasileira, v. 50, n. 8, p. 730-733.

ESTRUCH, J. J.; CAROZZI, N. B.; DESAI, N.; DUCK, N. B.; WARREN, G. W.; KOZIEL, M. G. 1997. Transgenic plants: an emerging approach to pest control. Nature Biotechnology, v. 15, p. $137-141$.

FINNEY, D. J. 1971. Probit analysis. Cambridge, England: Cambridge University Press, 31 p.

GALLO, D.; NAKANO, O.; SILVEIRA NETO, S.; CARVALHO, R. P. L.; BATISTA, G. C.; BERTI FILHO, E.; PARRA, J. R. P.; ZUCCHI, R. A.; ALVES, S. B.; VENDRAMIN, J. D.; MARCHINI, L. C.; LOPES, J. R. S.; OMOTO, C. 2002. Entomologia Agrícola. FEALQ, Piracicaba, v.10, 920p.

GOULET, E.; RUEDA, A.; SHELTON, A. 2005. Management of the mahogany shoot borer, Hypsipyla grandella Zeller (Lepidoptera: Pyralidae), through weed management and insecticidal sprays in 1- and 2-years-old Swietenia humilis Zucc. plantations. Crop Protection, n. 24, p. 821-828. 
HABIB, M. E. M.; ANDRADE, C. F. S. 1998. Bactérias entomopatogênicas. In: Controle microbiano de insetos. Ed. ALVES, S.B., FEALQ, Piracicaba, p. 383-446.

HIDALGO-SALVATIERRA, O.; PALM, J. D. 1973. Susceptibility of first instar larvae to Bacillus thuringiensis. In: GRIJPMA, P. (Ed.). Studies on the shoot borer Hypsipyla grandella (Zeller) Lep. Pyralidae. Vol. I: 88.

IBARGUTXI, M. A.; ESTELA, A.; FERRE, J.; CABALlERO, P. 2006. Use of Bacillus thuringiensis Toxins for Control of the Cotton Pest Earias insulate (Boisd.) (Lepidoptera: Noctuidae). Applied and Environmental Microbiology, v. 72, n. 1, p. 437-442.

KRYWUNCZYK, J.; FAST, P. G. 1980. Sorological relationships of the crystals of Bacillus thuringiensis var. israelensis. Journal of Invertebrate Pathology, v. 36, p. 139-140.

KWA, M. S. G.; MAAGD, R. A.; STIEKEMA, W. J.; VLAK, J. M. BOSCH, D. 1998. Toxicity and Binding Properties of the Bacillus thuringiensis Delta-Endotoxin Cry 1C to Cultured Insect Cells. Journal of Invertebrate Pathology, v. 71, p. 121-127.

LAEMMLI, U. K. 1970. Cleavage of structural proteins during the assembly of the head bacteriophage T4. Nature, v. 227, p. 680-685.

LUNZ, A. M; THOMAZINI, M. J.; MORAES, M. C. B.; NEVES, E. J. M.; BATISTA, T. F. C.; DEGENHARDT, J.; SOUSA, L. A.; OHASHI, O. S. 2009. Hypsipyla grandella em Mogno (Swietenia macrophylla): situação atual e perspectivas. Pesquisa Florestal Brasileira, n. 59, p. 45-55. 
MACEDO, C. L.; MARTINS, E. S.; MACEDO, L. L. P.; SANTOS, A. C.; PRAÇA, L. B.; GÓIS, L. A. B.; MONNERAT, R. G. 2012. Seleção e caracterização de Bacillus thuringiensis eficientes contra a Diatraea saccharalis (Lepidoptera: Crambidae). Pesquisa Agropecuária Brasileira, v. 47, n. 12, p. 1759-1765.

MONNERAT, R.; MASSON, L.; BROUSSEAU, R.; PUSZTAI-CAREY, M.; MORDAT, D.; FRUTOS, R. 1999. Differential activity and activation of Bacillus thruringiensis insecticidal proteins in Diamond moth, Plutella xylostella. Current Microbiology, v. 39, p. 159-162.

MONNERAT, R. G.; BRAVO, A. 2000. Proteínas bioinseticidas produzidas pela bactéria Bacillus thuringiensis: modo de ação e resistência. In: Controle Biológico, eds. Melo, I.S. e Azevedo, J.L, Jaguariúna, SP, Embrapa Meio Ambiente, v. 3, p.163-200.

MONNERAT, R. G.; MARTINS, E. S.; QUEIROZ, P. R.; ORDÚZ, P.; JARAMILLO, G.; BENINTENDE G. 2006. Genetic variability of Spodoptera frugiperda: Smith (Lepidoptera: Noctuidae) populations from Latin America is associated with variations in susceptibility to Bacillus thuringiensis Cry toxins. Applied and Environmental Microbiology, v. 72, p. 7029-7035.

MONNERAT, R.G.; BATISTA, A. C.; MEDEIROS, P. T.; MARTINS, E.; MELATTI, V.; PRAÇA, L. B.; DUMAS, V.; DEMO, C.; GOMES, A. C.; FALCÃO, R.; BERRY, C. 2007. Characterization of Brazilian Bacilus thuringiensis strains active against Spodoptera frugiperda, Plutella xylostella and Anticarsia gemmatalis. Biological Control, v. 41, p. 291295. 
PIGGOT, C. R.; ELLAR, D. J. 2007. Role of Receptors in Bacillus thuringiensis Crystal Toxin Activity. Microbiology and Molecular Biology, v. 71, n. 2, p. 255-281.

PRAÇA, L. B. 2012. Interações entre estirpes de Bacillus thuringiensis e híbridos de repolho visando o controle de Plutella xylostella e a promoção do crescimento vegetal. Tese de Doutorado em Agronomia. Universidade de Brasília/Faculdade de Agronomia e Medicina Veterinária, 141 f.

PRAÇA, L. B.; BATISTA, A. C.; MARTINS, E. S.; SIQUEIRA, C. B.; DIAS, D. G. de S.; GOMES, A. C. M. M.; FALCÃO, R.; MONNERAT, R. G. 2004. Estirpes de Bacillus thuringiensis efetivas contra insetos das ordens Lepidoptera, Coleoptera e Diptera. Pesquisa Agropecuária Brasileira, v. 39, p. 11-16.

QUESADA-MORAGA, E.; GARCIA-TÓVAR, E.; VALVERDE-GARCIA, P.; SANTIAGOALVAREZ, C. 2004. Isolation, geographical diversity and insecticidal activity of Bacillus thuringiensis from soils in Spain. Microbiological Research, v. 159, n. 1, p. 59-71.

SEBASTIÃO, I.; LEMES, A. R. N.; FIGUEIREDO, C. S.; POLANCZYK, R. A.; DESIDÉRIO, J. A.; LEMOS, M. V. F. 2015. Toxicidade e capacidade de ligação de proteínas Cry1 a receptores intestinais de Helicoverpa armigera (Lepidoptera: Noctuidae). Pesquisa Agropecuária Brasileira, v. 50, n. 11, p. 999-1005.

TABASHNIK, B. E. 1992. Evaluatin of synergism among Bacillus thuringiensis toxins. Applied Environmental Microbiology, v. 58, n. 10, p. 3343-3346. 
THOMAS, W. E.; ELLAR, D. J. 1983. Mechanism of action of Bacillus thuringiensis var. israelensis insecticidal delta-endotoxin. FEBS Letters, v. 154, p. 362-368.

VIANA, C. L. T. P.; DE BORTOLI, S. A.; THULER, R. T.; GOULAR, T. R. M.; THULER, A. M. G.; LEMOS, M. V. F.; FERRAUDO, A. S. 2009. Efeito de novos isolados de Bacillus thuringiensis Berliner em Plutella xylostella (Linnaeus, 1758) (Lepidoptera: Plutellidae). Científica, v. 37, n. 1, p. 22-31.

WHITELEY, H. R.; SCHNEPF, H. E. 1986. The molecular biology of parasporal crystal body formation in Bacillus thuringiensis. Annual Review of Microbiology, v. 40, p. 549576. 


\section{CAPÍtUlO 5}

\section{CONTROLE BIOLÓGICO DE Hypsipyla grandella Zeller (Lepidoptera: Pyralidae) COM O USO SISTÊMICO DE Bacillus thuringiensis Berliner EM MUDAS DE Swietenia macrophylla King}

\subsection{RESUMO}

Hypsipyla grandella Zeller, conhecida popularmente como broca do mogno, é a principal praga de Swietenia macrophylla King, limitando o estabelecimento do plantio comercial da espécie em todo o Brasil. Para contornar essa situação, estudos visando o manejo sustentável da praga são imprescindíveis. O uso sistêmico da bactéria Bacillus thuringiensis $(B t)$ para o controle de insetos-praga vem se tornando uma ferramenta promissora a ser incorporada em programa de manejo integrado de diversas pragas agrícolas e florestais. Com base nisso, esse trabalho teve como objetivo avaliar o uso de $B t$ em plantas de mogno para o controle de $H$. grandella. Para tanto, foram utilizadas cinco estirpes comprovadamete letais às lagartas recém-eclodidas, quando misturadas com sementes de mogno. No intuito de verificar o efeito sistêmico em mudas de mogno, a bactéria foi suspendida com água destilada autoclavada e a suspensão foi aplicada via solo na concentração de 1 x $10^{8}$ esporos por $\mathrm{mL}$, para cada tratamento. A testemunha consistiu de água destilada autoclavada sem bactéria. Para cada tratamento foram utilizadas seis mudas, e, em cada muda, foram colocados três ovos de $H$. grandella com 48 horas de idade. Portanto, foram utilizadas 36 mudas, dispostas em delineamento inteiramente casualizado, com 108 ovos de H. grandella no total. Após 30 dias, os parâmetros avaliados foram: presença ou ausência de goma, teia e excrementos, tamanho da galeria formada pelo inseto e o número de lagartas vivas/mortas no interior das plantas. Como resultado, as plantas tratadas com a estirpe S1905 apresentaram um ataque 
desacelerado em comparação com a testemunha, com sintomas e danos pouco aparentes, caracterizado por pouca exsudação de goma e pouca presença de excrementos e teia por parte do inseto. As plantas sem tratamento com $B t$ se mostraram completamente atacadas, com até três lagartas em seu interior, além de apresentarem as maiores galerias (até 15,7 cm de comprimento). Este trabalho é pioneiro no uso sistêmico de $B t$ em mudas arbóreas e esse método parece ser uma alternativa promissora e viável ao uso de inseticidas químicos. Apesar de ser um estudo preliminar, os resultados obtidos abrem um caminho ainda inexplorado na área florestal e que, futuramente, pode se tornar um dos principais métodos para o controle de insetos-praga, sobretudo com o uso de microrganismos sistêmicos.

Palavras-chave: broca do mogno, endofítico, controle biológico, praga florestal. 


\section{BIOLOGICAL CONTROL OF Hypsipyla grandella Zeller (Lepidoptera: Pyralidae) WITH THE SYSTEMIC USE OF Bacillus thuringiensis Berliner ON Swietenia macrophylla King SEEDLINGS}

\subsection{ABSTRACT}

Hypsipyla grandella Zeller, popularly known as mahogany shootborer, is the major pest of Swietenia macrophylla King, limiting the establishment of commercial planting of the species in Brazil. To work around this, studies for sustaintable pest management are essential. The systemic use of bacteria Bacillus thuringiensis $(B t)$ to control insect pests is becoming a promising tool to be incorporated in integrated pest management program for various agricultural and forest pests. Based on this, this study aimed to evaluate the use of $B t$ in mahogany plants for the control of $H$. grandella. For this, five strains used were chosen based on preliminary experiments, where all caused $100 \%$ of mortality in newly hatched larvae when mixed with mahogany seeds. In order to check the systemic effect in mahogany seedlings, the bacteria were mixed with autoclaves distilled water and the suspension was applied into the soil at a concentration of $1 \times 10^{8}$ spores per $\mathrm{mL}$ for each treatment. The witness consisted of distilled water autoclaved without bacteria. Each treatment was repeated with six plants, and in each seedling were placed three eggs of $H$. grandella 48 hours old. Therefore, we used 36 seedlings, arranged in a completely randomized design, with 108 eggs of $H$. grandella. After 30 days, the parameters evaluated were: presence or absence of gum, web and excrement, size of the gallery formed by the insect and the number of live caterpillars / dead inside the plant. As a result, the plants treated with the streain S1905 showed an attack decelerated compared with the control, with little apparent damage and symptoms, characterized by little exudate, gum, excrement and warp by the insect. The untreated plants with $B t$ proved completely attacked, with up to three caterpillars inside, in 
addition to having the largest galleries (up to $15.7 \mathrm{~cm}$ long). This word is a pioneer in systemic use of $B t$ in tree seedlings and this method seems to be a promising and viable alternative to using chemical insecticides. Despite being a preliminary study, the results open a follow untapped in the forest area and that in the future can become one of the main methods for the controle of insect pests, especially with the use of systemic microorganisms. Keywords: shoot borer, endophytic, biological control, forest pest. 


\subsection{INTRODUÇÃO}

Dentro da família Meliaceae, 13 gêneros são alvos de Hypsipyla grandella. No Brasil, ocorrem em mogno (Swietenia macrophylla King), cedro (Cedrella odorata L.) e andiroba (Carapa guianensis Aubl.), atacando ramos, brotos, folhas, frutos, casca (Taveras et al., 2004) e até mesmo a raiz (Yamazaki et al., 1990). Tentativas de cultivo de mogno fora de sua área de origem foram consideradas um fracasso devido às condições de cultivo, mudas de baixa qualidade e a incidência da Hypsipyla grandella Zeller (Carvalho, 2007).

O principal dano do inseto em árvores de mogno consiste na destruição do broto terminal em mudas e árvores novas, devido à entrada e escavação de galerias pelas lagartas (Grijpma, 1976). Os sintomas do ataque da lagarta são representados por exsudação de goma e serragem, presença de folhas secas em meio à folhagem verde e emissão de novos ponteiros a cada ataque consecutivo, que posteriormente também serão atacados (Silva, 1985; Griffiths, 2000, Ohashi et al., 2002). O crescimento de um tronco retilíneo é fortemente prejudicado (Grijpma, 1976; Ohashi et al., 2000), com perda em altura de até 35\% nos primeiros anos (Ohashi et al., 2005). Ataques repetitivos e intensos causam a morte da planta.

O plantio de mogno na região do Distrito Federal e Goiás, Brasil, se apresenta bastante promissor. Estudos realizados por Jacinto (2001) em árvores de Brasília mostraram que a espécie apresentou um crescimento primário e secundário bastante satisfatório, sendo passível de ser plantada de forma comercial. Porém, o ataque da $H$. grandella pode vir a prejudicar o estabelecimento do povoamento na região. Para contornar essa situação, medidas de controle devem ser estudadas e aprimoradas, para, então, aplicar medidas de manejo integrado dessa praga.

Os principais métodos de controle usualmente adotados para o controle da broca são (Lunz et al., 2009): uso de genótipos resistentes ao inseto; manejo silvicultural por meio da interferência na localização da planta hospedeira, redução da adequabilidade hospedeira, 
aumento de inimigos naturais e recuperação da forma e incremento da altura da planta; uso de semioquímicos; e o controle biológico, com o uso de fungos, vespas, nematoides e bactérias. O uso de inseticidas convencionais tem sido desaconselhável para o controle da broca por razões como o hábito do inseto (críptico), a natureza dos danos (internos na planta), fatores climáticos (pluviosidade intensa na região de ocorrência natural) e o longo período de proteção necessário, que o torna oneroso, impraticável e danoso para o meio ambiente (Wylie, 2001; Mahroof et al., 2002).

O uso de Bacillus thuringiensis Berliner, uma bactéria que produz proteínas tóxicas a diversas ordens de insetos, ocupa cerca de 1 a $2 \%$ do mercado de produtos usados como inseticidas de pragas agrícolas, florestais ou de vetores de doenças para o homem e animais (Estruch et al., 1996; Baum et al., 1999), conferindo níveis adequados e consistentes de controle. Algumas das vantagens da utilização de $B t$ são a sua alta especificidade em relação aos insetos sensíveis, seu efeito não poluente ao meio ambiente, sua inocuidade aos mamíferos e vertebrados e a ausência de toxicidade às plantas (Whiteley \& Schnepf, 1986).

Atualmente, não existem estratégias para controlar de forma eficaz e plena a incidência de $H$. grandella sobre as meliáceas de importância comercial. Devido a sua elevada importância comercial, ecológica e paisagística, o interesse de realizar pesquisas com o objetivo de preservar, conservar e garantir o uso sustentável do mogno é evidente, sendo necessárias pesquisas com o intuito de diminuir os prejuízos causados por essa praga. Portanto, esse trabalho tem como objetivo avaliar o uso de $B$. thuringiensis de forma sistêmica em plantas de mogno para o controle de $H$. grandella. 


\subsection{MATERIAL E MÉTODOS}

\subsubsection{Caracterização do local de realização dos experimentos}

O trabalho foi realizado em uma casa de vegetação da Embrapa Recursos Genéticos e Biotecnologia, Brasília, Distrito Federal. Segundo a classificação de Koppen, o clima da região é classificado como AW (clima tropical com chuvas no verão e seca no inverno), com a estação chuvosa de outubro a abril e seca de maio a setembro. A temperatura média anual é de $21{ }^{\circ} \mathrm{C}$ e umidade relativa do ar é de aproximadamente $70 \%$ (Weatherbase, 2015).

\subsubsection{Produção das mudas de mogno}

Para a produção de mudas, foram coletadas sementes de árvores de mogno utilizadas na arborização de Brasília, Distrito Federal, durante os meses de outubro a dezembro de 2013. Logo após a coleta, as sementes foram armazenadas em temperatura ambiente até a semeadura.

Em janeiro de 2014 foram plantadas aproximadamente 250 sementes de mogno em substrato PlantMax®. Após a germinação, as 200 melhores mudas foram selecionadas, regadas diariamente e adubadas trimestralmente com o fertilizante Osmocote ${ }$. Todo o processo de produção de mudas foi feito até maio de 2015, período de realização dos experimentos, com o uso de 36 mudas no total.

\subsubsection{Avaliações dendrométricas}

Em maio de 2015, as mudas (Figura 1) foram avaliadas quanto a sua altura, em centímetros, com o auxílio de uma trena, e o seu diâmetro medido com o uso de um paquímetro digital. Esta etapa foi realizada para a escolha das mudas quanto à inoculação da bactéria, a partir do diâmetro. Foram escolhidas as mudas com diâmetro superior a $1 \mathrm{~cm}$. 


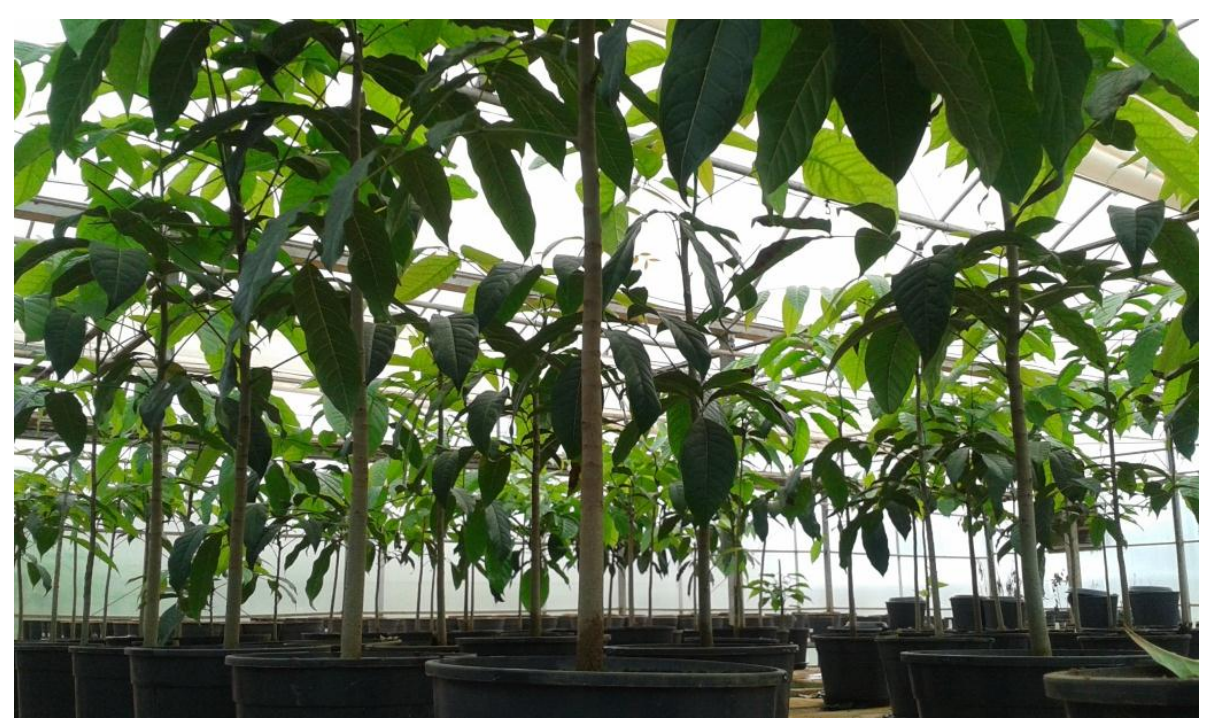

Figura 1. Mudas de mogno produzidas em casa de vegetação de janeiro de 2014 a maio de 2015.

\subsubsection{Tratamentos e delineamento experimental}

As estirpes de $B$. thuringiensis utilizadas no experimento foram escolhidas com base nos testes preliminares de ensaio de mortalidade, a saber: S1905, S2021, S2122, S2124, isoladas de solo e pertencentes à Coleção de Bactérias Entomopatogênicas da Embrapa Recursos Genéticos e Biotecnologia, e a estirpe Btk 1450 HD-1, obtida na Coleção de Bacillus thuringiensis e Lysinibacillus sphaericus do Instituto Pasteur de Paris. Todas essas estirpes causaram $100 \%$ de mortalidade em lagartas recém-eclodidas, quando misturadas com sementes de mogno.

Para cada tratamento foram utilizadas seis mudas, e, em cada muda, foram colocados três ovos de $H$. grandella com 48 horas de idade, com o auxílio de uma fita crepe, de modo a fixar o tecido "morim" na planta (Figura 2), conforme Silva Junior et al. (2014), com algumas modificações. Os ovos foram colocados próximos ao broto terminal da muda, com o propósito de facilitar a entrada das lagartas recém-eclodidas na planta. Portanto, foram 
utilizadas 36 mudas, dispostas em delineamento inteiramente casualizado, com 108 ovos de H. grandella.

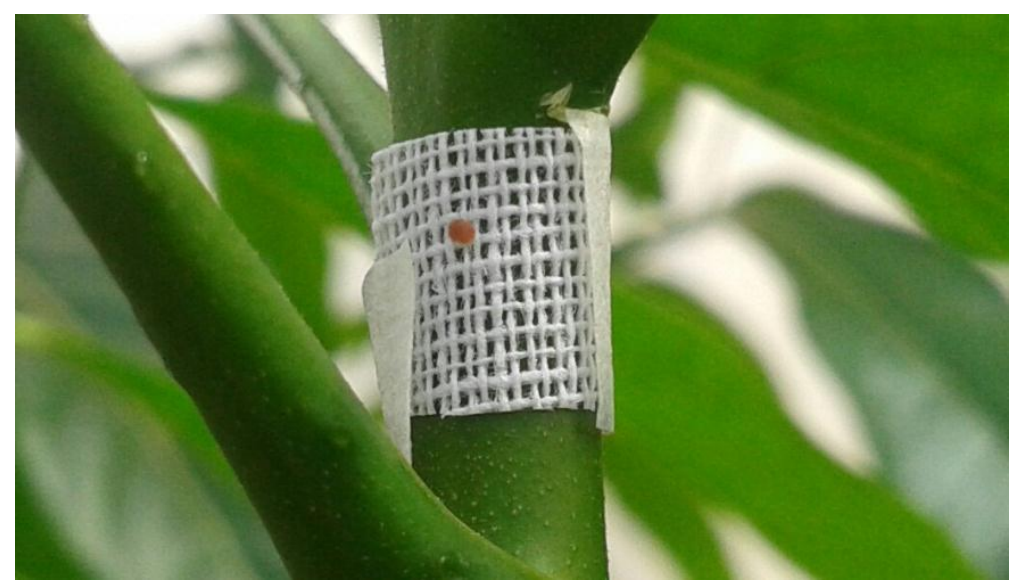

Figura 2. Ovo de Hypsipyla grandella em tecido fixado na planta de mogno com o auxílio de fita crepe.

\subsubsection{Produção e Inoculação de Bacillus thuringiensis}

As estirpes utilizadas neste ensaio foram produzidas em meio Embrapa (Monnerat et al., 2007) e incubadas em incubador rotativo. As estirpes foram visualizadas em microscópio óptico de contraste de fases com aumento de 1.000 x para observação de esporos e cristais. Para cada estirpe multiplicada em fermentador foram realizadas centrifugações a 9.500 por 30 minutos (Centrífuga Hettich Zentrifugen, modelo Rotanda 460R), o sobrenadante foi desprezado para obtenção de um pellet concentrado ao final do trabalho e posteriormente foi ressuspendido em água destilada, congelado e depois liofilizado em Liofilizador Christ, modelo Alpha 2-4 LD Plus. O material liofilizado foi acondicionado em tubos Falcon e armazenados $\mathrm{a}-20^{\circ} \mathrm{C}$.

Foi feita a contagem de esporos de todas as estirpes utilizadas através da determinação do número de unidades formadoras de colônia por $\mathrm{mL}$ (UFC/mL), a partir de diluições em série. Para tanto, em $5 \mathrm{~mL}$ de água destilada autoclavada foram diluídos 0,005 $\mathrm{g}$ da biomassa 
liofilizada contendo esporo-cristal (diluição $10^{-1}$ ). A diluição $10^{-1}$ foi homogeneizada em vórtex, e para a composição da diluição $10^{-2}$, foram acrescentadas $4,5 \mathrm{~mL}$ de água destilada autoclavada e $0,5 \mu \mathrm{l}$ da diluição anterior e assim sucessivamente. Todas as diluições foram plaqueadas em triplicata em placas de Petri contendo meio Embrapa Ágar (Monnerat et al., 2007) e foi utilizada a técnica da gota. Para cada replicata foram plaqueados $10 \mu \mathrm{l}$ da diluição correspondente com o auxílio de uma pipeta. As placas foram vedadas com filme PVC, de forma que o meio de cultura estivesse voltado para cima, e foram incubadas em estufa a $28{ }^{\circ} \mathrm{C}$ por aproximadamente 15 horas, para posterior contagem das UFC's.

Em seguida, depois de feita a contagem do número de esporos, o liofilizado bacteriano foi misturado com água destilada autoclavada e a suspensão foi inoculada via solo em uma única dose de $2 \mathrm{~mL}$ (Figura 3) na concentração de $1 \times 10^{8}$ esporos por mL, para cada tratamento. A testemunha consistiu de água destilada autoclavada sem o liofilizado bacteriano.

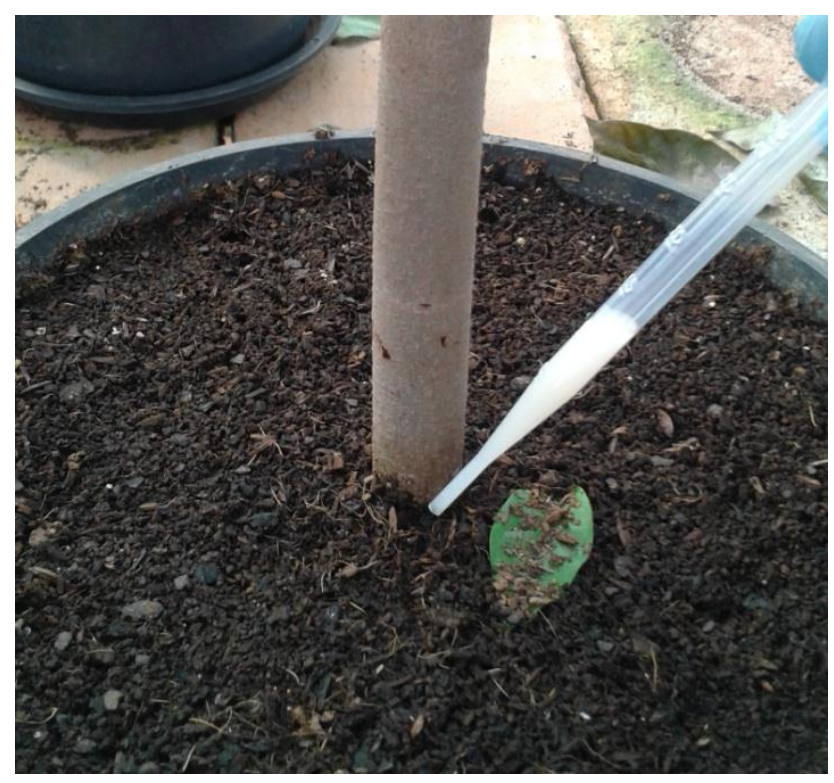

Figura 3. Inoculação da suspensão de Bacillus thuringiensis em mudas de mogno via solo. 


\subsubsection{Avaliação e parâmetros observados}

A avaliação perdurou até 30 dias após a inoculação. Durante esse período, foram observados diariamente os seguintes parâmetros:

1. Exsudação de goma no broto terminal ou na inserção das folhas;

2. Presença de teias de $H$. grandella;

3. Presença de excrementos de H. grandella;

4. Comportamento e ataque de H. grandella nas mudas;

5. Tamanho da galeria formada pela $H$. grandella, em centímetros.

6. Número de lagartas por planta;

7. Presença de lagartas mortas no interior das plantas.

Decorridos os 30 dias, foi observada a presença de pupas ou de lagartas de último instar $\left(6^{\circ}\right)$ em cada muda. Parâmetros relacionados ao desenvolvimento do inseto foram observados, como o atraso para empupar em relação à testemunha e averiguados para verificar se as plantas inoculadas com a bactéria poderiam apresentar algum efeito nocivo nas lagartas. $\mathrm{O}$ tamanho da galeria formada pela $H$. grandella se configura em um dos principais parâmetros para averiguar a eficiência de produtos ou da resistência do mogno ao ataque do inseto (Ohashi et al., 2002; Silva Junior et al., 2014).

\subsubsection{Análise estatística}

Os dados obtidos foram submetidos ao teste de Tukey a 1 e $5 \%$ de probabilidade, com o auxílio do programa Assistat. Para testar a eficiência das bactérias testadas, foi utilizada a fórmula de Abbot modificada (Abbot, 1925):

$$
\text { Eficiência }(\%)=(\text { PMT-PMTt/PMT }) \times 100
$$


Onde PMT é o número de plantas atacadas na testemunha e PMTt é o número de plantas atacadas no tratamento. Foi considerado eficaz o tratamento que obteve ao menos 80\% de eficácia (Nakano et al., 1981) e com galerias inferiores a dois centímetros. Foi verificada também a taxa de mortalidade das lagartas, uma vez que o inseto precisa ingerir a bactéria para que ocorra a sua morte. Além disso, as variáveis significativas foram submetidas ao teste de regressão entre o uso das estirpes de $B$. thuringiensis, o grau de infestação da broca nas mudas de mogno e o número de lagartas encontradas.

\subsection{RESULTADOS E DISCUSSÃO}

\subsubsection{Caracterização do ataque de $\boldsymbol{H}$. grandella em mudas de mogno}

Após dois dias, todas as lagartas eclodiram. Elas, frequentemente, penetraram primeiro na gema axilar ou no broto terminal e posteriormente se moveram e se alimentaram do entorno terminal não lignificado, incluindo a gema axilar, folhas novas e ponteiros dos ramos (Figura 4 - A). A alimentação continuou na medula, consumindo o floema e a medula, causando a destruição do ponteiro e consequente murcha das folhas mais novas. Em alguns casos, foi observado ataque no limbo foliar, em folhas isoladas (Figura 4 - B).

Após o ataque do inseto nas plantas, foi possível observar a presença de exsudação de goma, e, em todas as ocasiões, as lagartas protegeram seus sítios de entrada e alimentação construindo um tecido, o qual estava coberto com partículas de plantas e excrementos do inseto (Figura 4 - C). Essas estruturas protetoras também foram construídas antes da pupação, fato também observado por Vergara (1997). Não foi observada a presença de pupas até o final do experimento, apenas lagartas de variados íntares. Segundo Vergara (1997), as condições climáticas e a disponibilidade de alimento adequado afetam diretamente o seu ciclo de vida, podendo ser de quatro a seis semanas. 
No período de realização do experimento, não foi constatada a morte de nenhuma planta. Esses resultados indicam que se o inseto for detectado logo no início do ataque, os brotos podem ser podados para que a planta retome a sua dominância apical e não perca o seu valor comercial (Guimarães Neto et al., 2004).
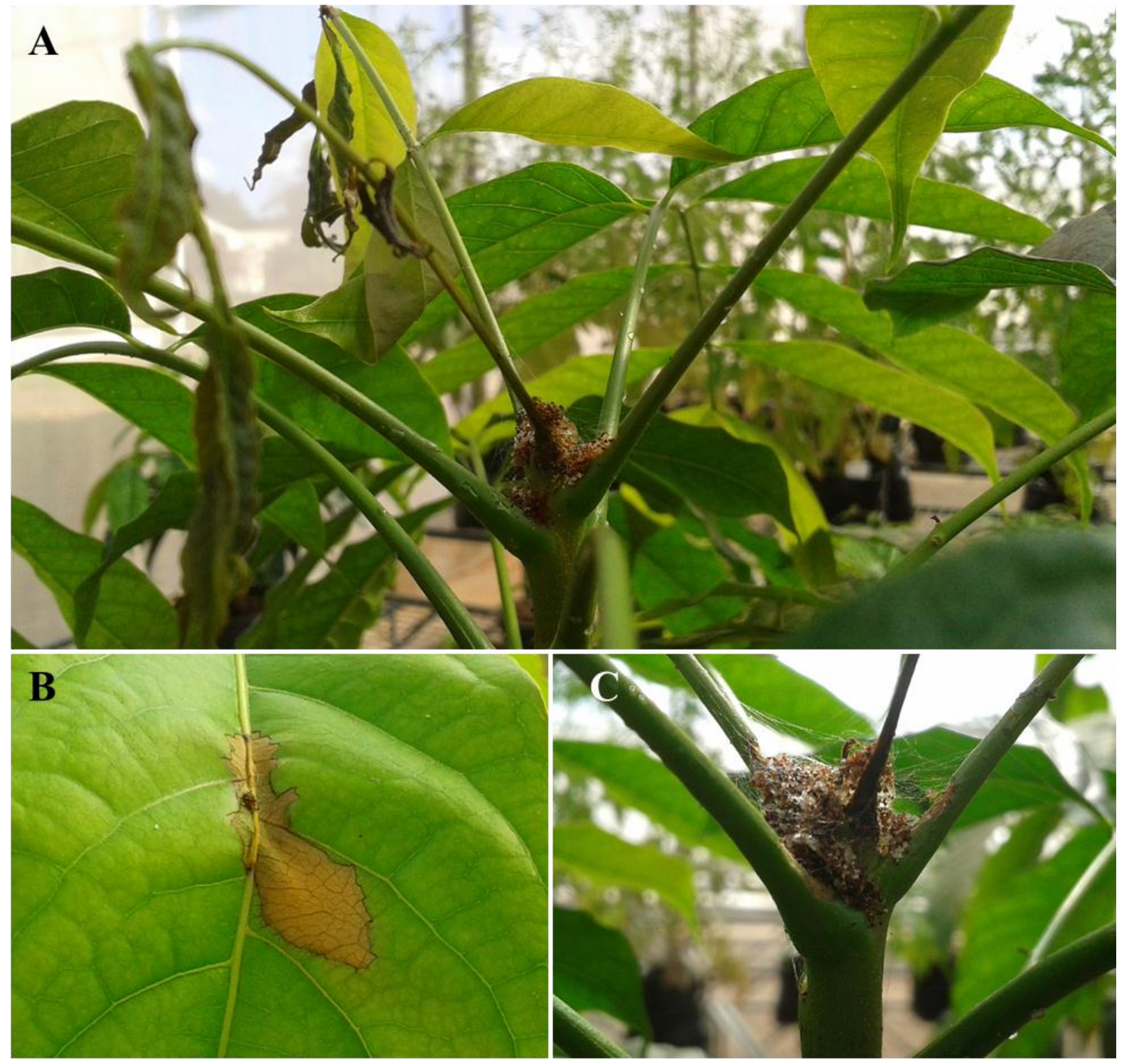

Figura 4 (A - C). Ataque de Hypsipyla grandella em mudas de mogno. A - Destruição do broto terminal e murcha de folhas novas, com a presença de excrementos do inseto e teia; $\mathrm{B}$ Lagarta na nervura central da folha. $\mathrm{C}$ - Detalhe da teia construída pela lagarta para proteger o sítio de alimentação. 
Após os 30 dias de experimento, 19 mudas se apresentaram debilitadas, sobretudo as plantas testemunhas, com os ponteiros totalmente destruídos (Figura 5 - A), galerias profundas no broto terminal (Figura 5 - B) e folhas e ramos novos completamente secos.
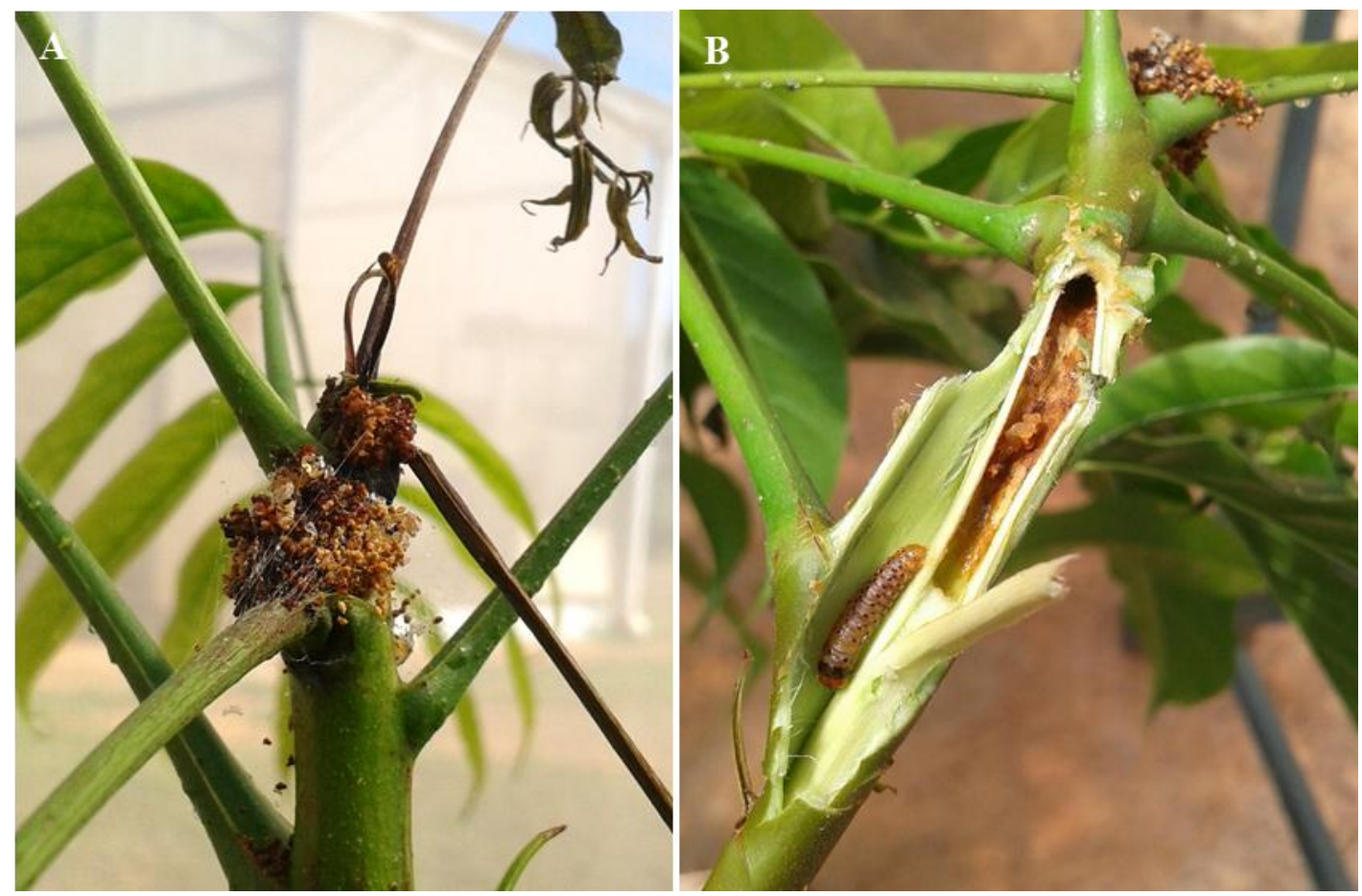

Figura 5 (A e B). Destruição da gema apical em muda de mogno pela Hypsipyla grandella. A

- Broto terminal completamente destruído pela $H$. grandella. B - Galeria formada pela lagarta ( $4^{\circ}$ instar).

\subsubsection{Avaliação do controle de $H$. grandella com o uso de estirpes de Bacillus thuringiensis via solo}

Todas as plantas que não foram inoculadas com a bactéria foram atacadas e, em algumas amostras, foram encontradas até três lagartas no interior dos ponteiros. Foram observadas, no total, 12 lagartas de diferentes ínstares (sobretudo do quarto ao sexto) nas plantas testemunhas. As galerias formadas pelo inseto nas plantas sem a bactéria foram as maiores observadas em todo o experimento, porém a estirpe $\mathrm{S} 2122$ não diferiu 
estatisticamente das plantas sem o $B t$, assim como o número de lagartas observadas no interior das plantas $(\mathrm{n}=11)$. Esse resultado sugere que a estirpe $\mathrm{S} 2122$ possivelmente não conseguiu se desenvolver e translocar nas plantas de mogno em quantidade suficiente para causar efeito adverso no inseto.

Uma vez dentro do hospedeiro, o microrganismo endofítico pode se alojar em tecidos específicos ou colonizar sistematicamente a planta, estabelecendo uma relação simbiótica, mutualística, comensal ou tropobiótica (Ulrich et al., 2008). Trabalhos recentes evidenciam que a capacidade da bactéria translocar na planta é proferida de acordo com a estirpe e o genótipo utilizado, o que indica que uma estirpe que seja eficaz no controle de uma determinada praga não necessariamente colonizará a planta de forma endofítica (Hardoim et al., 2008; Davitt et al., 2011; Costa, 2014).

Quanto à eficiência das bactérias testadas, de acordo com a fórmula de Abbot modificada, o único tratamento eficaz foi com a utilização da estirpe S1905 (Tabela 1), de acordo com o ataque e o tamanho das galerias formadas pelo inseto $(<2 \mathrm{~cm})$.

Tabela 1. Eficiência dos tratamentos bacterianos quanto à mortalidade de Hypsipyla grandella $\mathrm{e}$ tamanho médio da galeria formada pelo inseto em mudas de mogno inoculadas com $B t$ via solo.

\begin{tabular}{ccc}
\hline Estirpe & Eficiência & Tamanho médio da galeria $(\mathrm{cm})$ \\
\hline 1450 HD-1 & $16,7 \%$ & $8,22 \pm 2,29 \mathrm{ab}$ \\
S1905 & $83,3 \%$ & $2,20 \pm 0,73 \mathrm{~b}$ \\
S2021 & $50 \%$ & $5,83 \pm 1,74 \mathrm{~b}$ \\
S2122 & $0 \%$ & $15,22 \pm 1,24 \mathrm{a}$ \\
S2124 & $50 \%$ & $5,05 \pm 2,15 \mathrm{~b}$ \\
Testemunha & $0 \%$ & $13,55 \pm 0,96 \mathrm{a}$
\end{tabular}

* Médias seguidas da mesma letra não diferem estatisticamente entre si, ao nível de significância de 5\% - Tukey. 
As plantas inoculadas com a estirpe S1905 apresentaram um ataque desacelerado em comparação com a testemunha, com sintomas e danos pouco aparentes, caracterizado por pouca exsudação de goma e pequena presença de excrementos e teia por parte do inseto. Isso pode indicar um possível retardamento no desenvolvimento do inseto ou até mesmo sua morte. Além disso, foram contabilizadas quatro lagartas mortas no interior ou próximo das plantas (Figura 6), com sintomas característicos de infecção por Bt. As galerias formadas pelos insetos foram menores com esse tratamento (Tabela 1), realçando a hipótese de mortalidade por ingestão da bactéria.

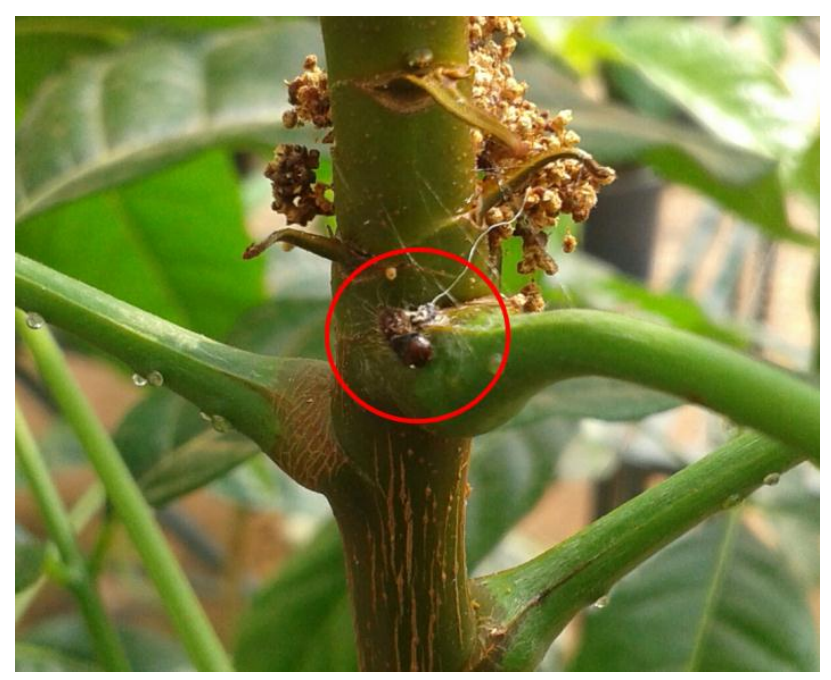

Figura 6. Lagarta morta de Hypsipyla grandella próxima ao broto terminal em planta de mogno inoculada com a bactéria Bacillus thuringiensis.

O tamanho das galerias nas plantas reflete o quanto as lagartas de $H$. grandella conseguiram ingerir e atacar o broto terminal das mudas, de acordo com o tempo. Galerias menores indicam um ataque desacelerado, e consequentemente, alimento não adequado e uma possível não preferência alimentar, ou até mesmo a morte do inseto. Este mesmo parâmetro foi utilizado por Silva Junior et al. (2014) ao analisar a resistência do mogno à $H$. grandella em função do uso de cálcio e boro. 
A maioria das plantas, em todos os tratamentos utilizados, apresentou sintomas típicos do ataque da $H$. grandella, como a confecção de teia pelo inseto, exsudação de goma, excrementos e a presença de folhas secas. O tratamento que apresentou o menor número de plantas que exibiram esses sinais foi com a estirpe 1905 (Figura 7).

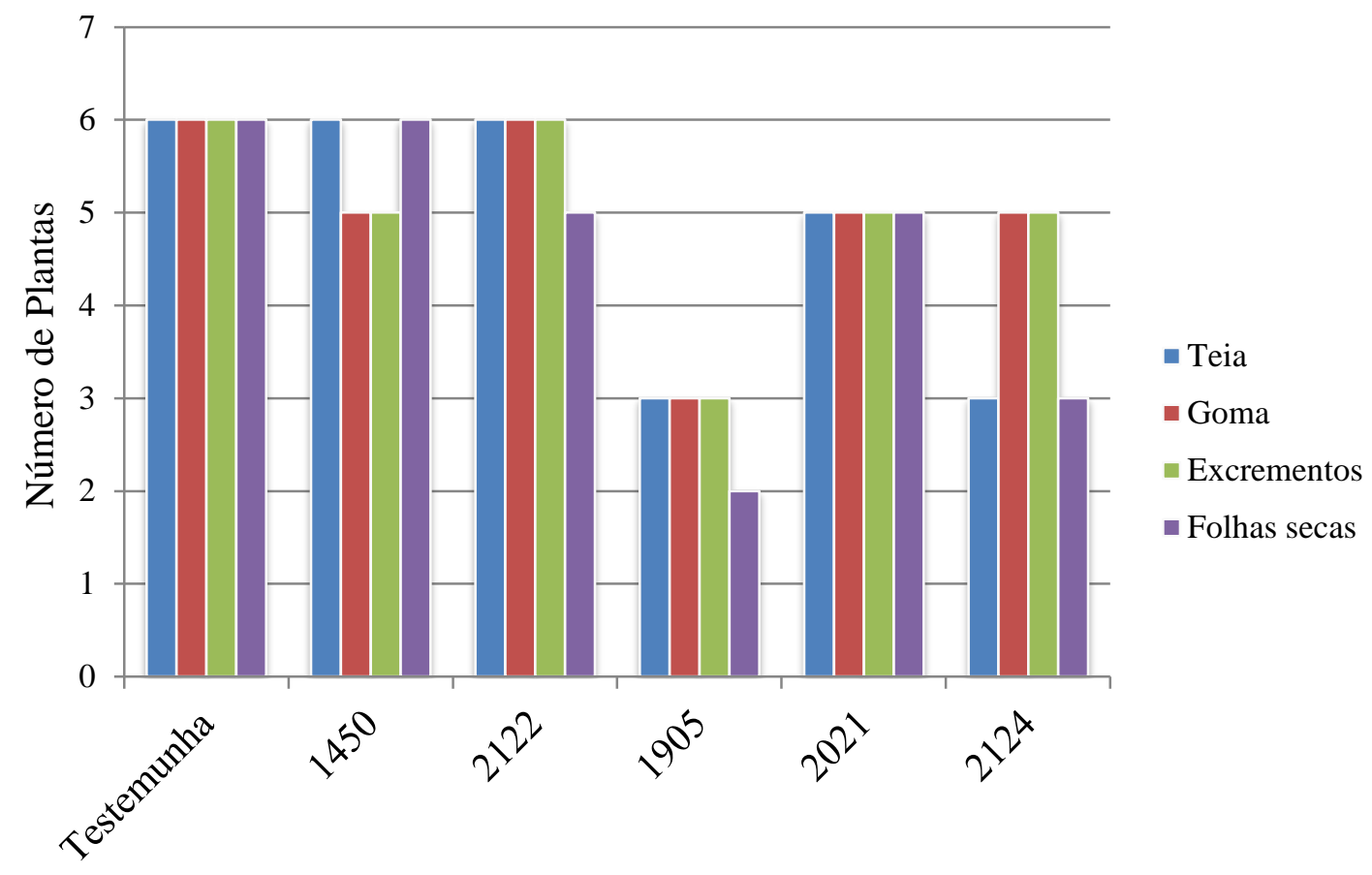

Figura 7. Número de plantas que apresentaram teia, exsudação de goma, excrementos e folhas secas de acordo com o uso de diferentes tratamentos quanto ao ataque de Hypsipyla grandella.

A incidência do ataque da $H$. grandella tem uma tendência de acompanhar os índices pluviométricos, com um maior ataque no período chuvoso (Ribeiro, 2010). Grijpma \& Roberts (1975) constataram que o uso de inseticidas pulverizados não tem obtido êxito para o controle do inseto devido à alta pluviosidade onde as meliáceas são comumente plantadas. Portanto, o uso de inseticidas sistêmicos se torna tão necessário. Wagner et al. (1991) relataram que inseticidas sistêmicos proporcionaram proteção parcial às plantas de mogno em 
Gana. Os compostos usualmente estudados para o controle da $H$. grandella de forma sistêmica são primordialmente químicos, sobretudo o acefato (Ribeiro, 2010).

Os resultados indicam que algumas estirpes de $B t$ utilizadas no experimento possuem algum efeito sistêmico em mudas de mogno, com capacidade de translocação via vasos condutores. Estudos realizados por Bizarri \& Bishop (2007) e Maduell et al. (2007) indicam que as estirpes de $B t$ encontradas no solo e no filoplano são as mesmas e que as bactérias algumas vezes são transportadas do solo para as folhas. Hinton \& Bacon (1995) demostraram que a colonização de $B t$ de forma endofítica pode começar com a migração de bactérias para locais onde as raízes estejam crescendo e sementes germinando. Monnerat et al. (2003) demonstraram que $B t$ coloniza tecidos de plantas de algodão e que algumas estirpes uma vez inoculadas nos solos próximos às raízes de plantas de algodão e de couve, espalham-se para todos os tecidos, chegando aos insetos (Monnerat et al., 2009), podendo causar a sua mortalidade. Praça (2012) ilustrou e confirmou a translocação de $B t$ em híbridos de repolho, além de promover o crescimento vegetativo. Coêlho et al. (2011) isolaram bactérias endofíticas do gênero Bacillus, Pantoea e outras duas não cultivada em meio de cultura em três espécies arbóreas da Amazônia, incluindo o mogno.

A colonização de microrganismos benéficos em mogno como o $B t$, pode ser uma opção importante ao uso de produtos químicos para o controle de H. grandella. Para tanto, investigações mais aprofundadas e testes com o liofilizado em árvores, sobretudo com a estirpe S1905, devem ser realizados a fim de estabelecer essa metodologia e formular um produto comercial a base de $B$. thuringiensis.

\subsection{CONCLUSÕES}

- As estirpes de Bacillus thuringiensis utilizadas possuem diferentes efeitos tóxicos à Hypsipyla grandella quando inoculadas via solo; 
- A estirpe S1905 se mostrou promissora no controle de H. grandella via efeito sistêmico em plantas de mogno, com eficiência de $83,3 \%$.

\subsection{REFERÊNCIAS BIBLIOGRÁFICAS}

ABBOT, W. S. 1925. A method of computing the effectiveness of an insecticide. Journal of Economic Entomology, v. 18, p. 265-266.

BAUM, J.A.; JOHNSON, T.B.; CARLTON, B.C. 1999. Bacillus thuringiensis. Natural and recombinant bioinsecticide products. Methods Biotechnology, v. 5, p. 189-209.

BIZARRI, M. F.; BISHOP, A. H. 2007. Recovery of Bacillus thuringiensis in vegetative form from phylloplane of clover (Trifolium hybrindum) during a growing season. Journal of Invertebrate Pathology, v. 94, p. 38-47.

CARVALHO, P. E. R. 2007. Mogno - Swietenia macrophylla. Colombo, Paraná, Embrapa Florestas. Circular Técnico 140, p. 12.

COSTA, F. S. S. 2014. Bacillus thuringiensis como endofíticos em algodão: avaliação na promoção de crescimento e controle de Spodoptera frugiperda. Dissertação (Mestrado em Agronomia) - Universidade de Brasília, Brasília, 99 f.

COÊLHO, M. M.; FERREIRA-NOZAWA, M. S.; NOZAWA, S. R.; SANTOS, A. L. W. 2011. Isolation of endophytic bactéria from arboreal species of the Amazon and identification by sequencing of the 16S rRNA enconding gene. Genetics and Molecular Biology, v. 34, n. 4, p. 676-680. 
DAVITT, A. J.; CHEN, C.; RUDGERS, J. A. 2011. Understanding context-dependency in plant-microbe symbiosis: the influence of abiotic and biotic contexts on host fitness and the rate of symbiont transmission. Environmental and Experimental Botany, v. 71, p. 137-145.

ESTRUCH, J. J.; WARREN, G. W.; MULLINS, M. A.; NYE, G. J.; GRAIG, J. A.; KOZIEL, M. G. 1996. VIP3A, A novel Bacillus thuringiensis vegetative insecticidal protein with a wide spectrum of activities against lepidopteran insects. Proceedings of the National Academics of Sciences. v. 93, p. 5389-5394.

GRIJPMA, P. 1976. Resistance of Meliaceae against the shoot borer Hypsipyla with particular reference to Toona ciliata M. J. Roem. var. australis (F.v. Muell.) CDC. In: BURLEY, J.; STYLES, B.T., ed. Tropical trees: variation breeding and conservation. London, Linnaean Society, p. 69-78.

GRIJPMA, P.; ROBERTS, S. C. 1975. Studies on the shootborer Hypsipyla grandella Zeller (Lep., Pyralidae). XXVIII Biological and chemical screening for the basis of resistance of Toona ciliata M. J. Roem. var. australis (F. v. M.) C. D. C. Turrialba, v. 25, p. 152-159.

GRIFFITHS, M. W. 2000. The biology and host relations of the red cedar tip moth, Hypsipyla robusta, in Australia. In: SNELL, A.; VIZE, S. (Ed.) Opportunities for the New Millennium: Proceedings of the Australian Forest Growers Biennal Conference. Canberra: Australian Forest Growers, p. 135-140. 
GUIMARÃES, NETO, A. B.; FELFILI, J. M.; SILVA, G. F.; MAZZEI, L.; FAGG, C. W.; NOGUEIRA, P. E. 2004. Avaliação do plantio homogêneo de mogno, Swietenia macrophylla King, em comparação com o plantio consorciado com Eucalyptus urophylla S. T. Blake, após 40 meses de idade. Revista Árvore, Viçosa - MG, v. 28, n. 6, p. 777-784.

HARDOIN, P. R.; VAN OVERBEEK, L. S.; VAN ELSAS, J. D. 2008. Properties of bacterial endophytes and their proposed role in plant growth. Trends Microbiology, v. 16, p. 463-471.

HINTON, D. M.; BACON, C. W. 1995. Enterobacter cloacae is an endophytic symbiont of corn. Mycopathologia, Dortrecht, v. 129, p. 117-125.

JACINTO, J. M. de M. Análise silvicultural urbana de seis espécies florestais utilizadas na arborização de Brasília. (Dissertação de Mestrado em Ciências Florestais). Brasília, DF, 2001. 65 p.

LUNZ, A. M; THOMAZINI, M. J.; MORAES, M. C. B.; NEVES, E. J. M.; BATISTA, T. F. C.; DEGENHARDT, J.; SOUSA, L. A.; OHASHI, O. S. 2009. Hypsipyla grandella em Mogno (Swietenia macrophylla): situação atual e perspectivas. Pesquisa Florestal Brasileira, n. 59, p. 45-55.

MADUELL, P.; ARMENGOL, G.; LIAGOSTERA, M.; LINDOW, S.; ORDUZ, S. 2007. Immigration of Bacillus thuringiensis to bean leaves from soil inoculums or distal plant parts. Journal of Applied Microbiology, v. 103, p. 2593-2600. 
MAHROOF, R. M.; HAUXWELL, C.; EDIRISINGHE, J. P.; WATT, A. D.; NEWTON, A. C. 2002. Effects of artificial shade on attack by the mahogany shoot borer, Hypsipyla robusta (Moore). Agricultural and Forest Entomology, Midlothian, n. 4, p. 283-292.

MONNERAT, R. G.; SANTOS, R.; BARROS, P.; BATISTA, A.; BERRY, C. 2003. Isolamento e caracterização de estirpes de Bacillus thuringiensis endofíticas de algodão. Brasília, Embrapa Recursos Genéticos e Biotecnologia, 4 p. (Embrapa Recursos Genéticos e Biotecnologia, Comunicado Técnico, 98).

MONNERAT, R.G., BATISTA, A. C., MEDEIROS, P. T., MARTINS, E., MELATTI, 1 V., PRAÇA, L., DUMAS, V., DEMO, C., GOMES, A. C., FALCÃO, R.; BERRY, C. 2007. Characterization of Brazilian Bacilus thuringiensis strains active against Spodoptera frugiperda, Plutella xylostella and Anticarsia gemmatalis. Biological Control, v. 41, p. 291295.

MONNERAT, R. G.; SOARES, C. M. S.; GOMES, A. C. M.; JONES, G.; MARTINS, E.; PRAÇA, L. B.; BERRY, C. 2009. Translocation and insecticidal activity of Bacillus thuringiensis bacteria living inside of plants. Microbial Biotechnology, v. 2, p. 1560-1562.

NAKANO, O.; SILVEIRA NETO, S.; ZUCCHI, R. A. 1981. Entomologia Econômica. São Paulo: Livroceres, 314 p.

OHASHI, O. S.; COSTA, M. S. S.; SILVA, J. N. M.; SILVA, M. F. G. G. 2000. Resistência do tipo antibiose apresentada pelas folhas novas de Toona ciliata M. J. Roem às lagartas 
de Hypsipyla grandella Zeller. Comunicado Técnico, 48. Belém: Embrapa Amazônia Oriental. $3 \mathrm{p}$.

OHASHI, S. T.; SILVA, J. N. M.; SILVA, M. E. C. E.; COSTA, M. S. S.; SARMENTO JUNIOR, R. G.; SANTOS, E. B.; ALVES, M. Z. N.; PESSOA, A. M. C.; SILVA, T. C. O.; BITTENCOURT, P. R. G.; BARBOSA, T. C.; SANTOS, T. M. 2002. Manejo Integrado da Broca do Mogno Hypsipyla grandella Zeller (Lep. Pyralidae). In: POLTRONIERI, L. S.; TRINDADE, D. R. Manejo integrado das principais pragas e doenças de cultivos amazônicos. Belém: Embrapa Amazônia Oriental, 304 p.

OHASHI, O. S.; SILVA JUNIOR, M. L.; LAMEIRA, O. A.; SILVA, J. N. M.; LEÃO, N. V. M.; TEREZO, E. F.; BATISTA, T. F. C.; HIDAKA, D. Z. L.; ALMEIDA, G. B.; BITTENCOURT, P. R. G.; GOMES, F. S.; NEVES, G. A. M. 2005. Danos e controle da broca de Hypsipyla grandella em plantio de mogno no Estado do Pará. In: POLTRONIERI, L. S.; TRINDADE, D. R.; SANTOS, I. P. Pragas e doenças de cultivos Amazônicos. Belém, Embrapa Amazônia Oriental, 483 p.

PRAÇA, L. B. 2012. Interações entre estirpes de Bacillus thuringiensis e híbridos de repolho visando o controle de Plutella xylostella e a promoção do crescimento vegetal. Tese de Doutorado em Agronomia. Universidade de Brasília/Faculdade de Agronomia e Medicina Veterinária, $141 \mathrm{f}$.

RIBEIRO, A. M. B. 2010. Controle químico da broca das melíaceas Hypsipyla grandella Zeller (Lepidoptera : Pyralidae) em mogno sul americano (Swietania macrophylla King). Dissertação de Mestrado em Ciência Florestal. UNESP - Botucatu. 75 p. 
SILVA, N. M. 1985. Características biológicas e demográficas de Hypsipyla grandella (Zeller, 1848) (Pyralidae, Lepidoptera) e níveis de infestação sob dois sistemas de plantio de Carapa guianensis Aubl. (Meliaceae) no Amazonas. Dissertação (Mestrado em Ciências Biológicas), Departamento de Ciências Fundamentais e Desenvolvimento Agrícola, Instituto Nacional de Pesquisas da Amazônia, 103 f.

SILVA JÚNIOR, M. L.; SOUZA JÚNIOR, J. C.; BRAGA, A. C. M.; OHASHI, O. S.; MELO, V. S.; SILVA, G. R.; PEDROSO, A. J. S.; VIÉGAS, I. J. M.; SALDANHA, E. C. M. 2014. Crescimento de mogno-brasileiro e resistência a Hypsipyla grandella em função do cálcio e do boro. Revista Árvore, Viçosa - MG, v. 38, n. 6, p. 1085-1094.

TAVERAS, R.; HILJE, L. CARBALLO, M. 2004. Development of Hypsipyla grandella (Zeller) (Lepidoptera: Pyralidae) in response to constant temperatures. Neotropical Entomology, n. 33, p. 1-6.

ULRICK, K.; ULRICK, A.; EDWALD, D. 2008. Diversity of endophytic bacterial communities in poplar grown under field conditions. FEMS Microbiology Ecology, v. 63, p. 169-180.

VERGARA, B. J. A. 1997. Aproximación hacia un manejo integrado del barrenador de las Meliacea, Hypsipyla grandella Zeller. Revista Forestal Venezoelana, v. 41, n. 1, p. 23-28.

WAGNER, M. R.; ATUAHENE, S. K. N.; COBBINAH, J. R. 1991. Forest Entomology in West Tropical Africa: Forest Insects of Ghana. Kluwer Academic Press, Dordrecht, 210 p. 
WEATHERBASE, 2015. Disponível em: http://www.weatherbase.com/. Acessado em maio de 2015.

WHITELEY, H. R.; SCHNEPF, H. E. 1986. The molecular biology of parasporal crystal body formation in Bacillus thuringiensis. Annual Review of Microbiology, v. 40, p. 549576.

WYLIE, F. R. 2001. Control of Hypsipyla spp. shoot borers with chemical pesticides: a review. In: FLOYD, R. B.; HAUXWELL, C. (Ed.) Hypsipyla Shoot Borers in Meliaceae: Proceedings of an International Workshop. Canberra: Australian Centre for International Agricultural Research, p. 109-117.

YAMAZAKI, S.; TAKETANI, A.; FUJITA, K. VASQUES, C.; IKEDA, T. 1990. Ecology of Hypsipyla grandella and its seasonal changes in population density in Peruvian Amazon forest. Japan Agricultural Quarterly, n. 24, p. 149-155. 


\section{CAPÍTULO 6}

\section{ÁCAROS ASSOCIADOS AO MOGNO (Swietenia macrophylla King) NO BRASIL - NOVOS RELATOS E IDENTIFICAÇÃO DE UMA NOVA ESPÉCIE DA FAMÍLIA ERIOPHYIDAE}

\subsection{RESUMO}

O mogno (Swietenia macrophylla King) possui uma madeira de elevada qualidade e é uma espécie muito utilizada como ornamental na arborização de diversas cidades brasileiras. Ao conduzir um ensaio com mudas de mogno em uma casa de vegetação, foram observados sintomas causados por ácaros. Até o presente momento nenhuma espécie de ácaro havia sido relatada associada ao mogno no mundo. Portanto, esse trabalho teve como objetivo identificar e descrever sintomas de dois ácaros associados ao mogno, assim como realizar estudo taxonômico de uma espécie identificada como nova para a ciência. Para tanto, mudas sintomáticas foram coletadas e analisadas para a identificação dos ácaros. Além disso, amostras de folhas e ramos de árvores de mogno próximas ao experimento também foram coletadas e examinadas. Foram encontrados dois ácaros: uma nova espécie de Eriophyidae e a espécie Eutetranychus banksi (McGregor) (Acari: Tetranychidae). Foi feito um estudo morfológico da nova espécie, que está em fase de publicação. A espécie já conhecida pela ciência, E. banksi, apesar de ter um amplo espectro de hospedeiros, é pela primeira vez relatada em mogno.

Palavras-chave: Eriophyidae, Tetranychidae, Acari, espécie florestal nativa, taxonomia. 


\section{MITES ASSOCIATED WITH MAHOGANY (Swietenia macrophylla King) IN BRAZIL - NEW REPORTS AND IDENTIFICATION OF A NEW SPECIES OF ERIOPHYIDAE}

\subsection{ABSTRACT}

Mahogany (Swietenia macrophylla King) has an extremely high quality wood and it's used as an ornamental tree in several Brazilian cities. When conducting a test with mahogany seedlings in a greenhouse, symptoms caused by mites were observed. To date, no species of mite had been reported associated with mahogany in the world. Therefore, this study aimed to identify and describe symptoms of two mites associated with mahogany, and perform taxonomic study of a species identified as new to science. To this, symptomatic plants were collected and analyzed for the identification of mites. In addition, samples of leaves and branches of mahogany trees next to the experiment were collected and examined. Two mites were found: a new species of Eriophyidae and Eutetranychus banksi (McGregor) (Acari: Tetranychidae). It was made a morphological study of the new species, which is about to be published. The species already known to science, E. banksi, despite having a broad host range, is first reported in mahogany.

Keywords: Eriophyidae, Tetranychidae, Acari, native forest species, taxonomy. 


\subsection{INTRODUÇÃO}

O mogno (Swietenia macrophylla King) é uma espécie arbórea nativa da região amazônica extremamente apreciada pela alta qualidade de sua madeira. O plantio em larga escala dessa árvore é limitado devido à ocorrência da Hypsipyla grandella Zeller (Lepidoptera: Pyralidae), um inseto que se alimenta, sobretudo, da gema apical da planta, causando bifurcações (Carvalho, 2007). Além dessa Lepidoptera, poucos organismos foram relatados associados ao mogno. Segundo Moares e Flechtmann (2008), várias espécies de ácaros são consideradas pragas severas de diversos cultivos. As superfamílias Tetranychoidea e Eriophyoidea são as duas superfamílias de ácaros fitófagos de maior importância econômica, sendo que em Tetranychoidea são encontrados cerca de $60 \%$ das espécies-pragas de importância agrícola e florestal (Moraes, 1992).

Alguns ácaros eriofídeos (Eriophyoidea) são reconhecidos como pragas importantes em culturas agrícolas e florestais no mundo (Lindquist et al., 1996). Seus estiletes injetam saliva nas células vegetais e sugam o conteúdo celular (de Lillo et al., 2002), causando alterações citológicas, bioquímicas e fisiológicas nas plantas atacadas (de Lillo \& Monfreda, 2004; Petanovic \& Kielkiewicz, 2010a). Esse grupo de ácaros induzem malformações de plantas como galhas, sintomas complexos, causando distúrbios no crescimento das plantas, ou são vetores de patógenos (Petanovic \& Kielkiewicz, 2010b). Entretanto, cerca da metade das espécies conhecidas de eriofídeos são vagrantes na superfície das folhas e não causam danos aparentes (Huang, 2008; Shoracka et al., 2010; Petanovic \& Kielkiewicz, 2010b). Usualmente os eriofídeos são pequenos e difíceis de serem vistos a olho nu. Às vezes os sintomas do ataque podem ser confundidos com viroses, deficiência de nutrientes e desordens fisiológicas (Van Leewen et al., 2010).

A família Tetranychidae compreende um grande número de ácaros estritamente fitófagos e inclui pragas importantes para a agricultura nacional e mundial. É a família que 
apresenta espécies que causam os mais severos danos à agricultura (Lindquist, 1985). Mais de 100 espécies são nocivas a plantas cultivadas e 10 se destacam pelos prejuízos no campo (Migeon \& Dorkeld, 2006). Esses ácaros têm sido referidos como "ácaros-de-teia", na literatural nacional, e como "spider mites", dado o comportamento de muitas espécies de produzir quantidades variáveis de teia (Moraes \& Flechtmann, 2008). Suas injúrias nas plantas são provocadas pela ação dos estiletes que esvaziam o conteúdo celular da epiderme e parênquima, que são ocupadas por ar, resultando no aparecimento de pontuações translúcidas, dando origem a áreas prateadas ou verde-pálidas, devido à remoção dos cloroplastos. Ocorre também a oxidação das áreas atacadas, conferindo tons bronzeados à folha, e em ataques intensos a folha pode apresentar manchas necróticas, rasgadura e até a sua queda (Moraes \& Flechtmann, 2008).

Até o presente momento, nenhuma espécie de ácaro foi descrita associada ao mogno no mundo. Portanto, esse trabalho teve como objetivo identificar e descrever sintomas de duas espécies de ácaros encontrados na espécie, assim como realizar estudo taxonômico de uma espécie identificada como nova para a ciência.

\subsection{MATERIAL E MÉTODOS}

\subsubsection{Coleta do material para análise}

No primeiro semestre de 2014, durante a condução de aproximadamente 200 mudas de mogno em casa de vegetação em Brasília/DF para futuros ensaios, foram observados sintomas foliares que, ao serem examinados ao microscópio estereoscópio, revelaram a presença de ácaros. As mudas que apresentaram sintomas foram então levadas ao Laboratório de Entomologia e Acarologia da Quarentena Vegetal para análise e identificação dos mesmos. Com o objetivo de verificar se as árvores de mogno próximas ao ensaio também estavam com ácaros, foram coletados aleatoriamente ramos e folhas, com ou sem sintomas típicos de 
ácaros, com o auxílio de um podão, acomodados em saco plástico e colocados na geladeira até a análise.

Já em 2015, foram observados outros sintomas nas folhas das mudas, diferentes dos anteriores. As folhas foram examinadas em microscópio estereoscópico e outra espécie de ácaro foi encontrada. As mudas com os sintomas foram separadas para análise.

\subsubsection{Inspeção dos ácaros, preservação, montagem e identificação}

Os ácaros foram visualizados preliminarmente em microscópio esteresocópio, retirados das folhas de mudas de mogno com uma agulha e então transferidos para um pote plástico com álcool 70\% para preservação ou então foram prontamente montados em lâmina.

Uma grande quantidade de indivíduos de uma espécie de ácaro da família Eriophyidae foi obtida a partir da lavagem das folhas com detergente em um balde plástico de $5 \mathrm{~L}$ e peneiramento através do uso de um conjunto de três peneiras metálicas granulométricas com telas de malha gradualmente mais fina (1,00 mm 16 Mesh; $500 \mathrm{~mm} 32 \mathrm{Mesh}, 53 \mathrm{~mm} 270$ Mesh) em ordem decrescente de abertura. Os detritos de maior espessura ficaram retidos nas duas primeiras peneiras e os de menor espessura, incluindo os ácaros, na terceira peneira, a qual foi separada e lavada com jatos de álcool etílico $70 \%$ para minimizar a espuma do detergente. A solução em álcool resultante dessa lavagem foi vertida em um frasco plástico com álcool $70 \%$ até a análise.

A montagem das lâminas foi feita em meio Berlese modificado (Amrine \& Manson, 1996), onde foram colocados, em média, sete indivíduos sem diferenciação de sexo ou estágio de desenvolvimento. As preparações foram mantidas em estufa à $55^{\circ} \mathrm{C}$ durante 10 a 12 dias, para clarificação dos espécimes e secagem do meio de montagem. Após esse período, as lâminas foram seladas com esmalte incolor nas bordas das lamínulas e, posteriormente, armazenadas em caixas para lâminas. 
Foram realizadas observações morfológicas, medidas morfométricas e registros fotográficos de fêmeas (10), machos (5) e imaturos (5), com o auxílio de um microscópio óptico de contraste de fases. Foram medidos 70 caracteres comumente utilizados para a descrição de novas espécies de Eriophyoidea, com o uso de microscópio óptico com aumento de 100x em óleo de imersão. As medições foram realizadas utilizando uma ocular micrométrica acoplada ao microscópio. As medidas foram dadas em micrômetros $(\mu \mathrm{m})$. Para as fêmeas, cada medida do holótipo precedeu da amplitude de variação das medidas dos parátipos. As técnicas e procedimentos utilizados para montagem, armazenamento das lâminas e estudo morfológico dos Eriophyidae foram feitos com base em De Lillo et al. (2010) e a terminologia da descrição e a classificação da espécie foi baseada em Amrine et al. (2003).

O ácaro Eriophyidae foi desenhado com lápis utilizando a câmera clara do microscópio em papel do tipo nankin, com aumento de 100x da objetiva. O material foi escaneado e posteriormente retocado em computador com o auxílio do programa Adobe Ilustrator ${ }^{\circledR}$. Medidas foram feitas a partir de uma ocular micrométrica, também com a objetiva de 100x.

O ácaro Tetranychidae foi inspecionado em microscópio estereoscópio e os indivíduos foram retirados das folhas com uma agulha e colocados em recipiente plástico contendo álcool $70 \%$ até a identificação.

A identificação do Eriophyidae foi realizada pela Dra. Denise Návia, pesquisadora da Embrapa Recursos Genéticos e Biotecnologia, Quarentena Vegetal, Laboratório de Entomologia e Acarologia e a do Tetranychidae pelo prof. Dr. Carlos Flechtmann, da ESALQ - Universidade de São Paulo. A espécie nova de Eriophyidae está depositada na Coleção de Referência de Ácaros do Labotarório de Quarentena Vegetal da Embrapa Recursos Genéticos, Brasília, Distrito Federal. 


\subsection{RESULTADOS E DISCUSSÃO}

Foram encontradas duas espécies de ácaros, sendo uma da família Eriophyidae e outra da família Tetranychidae.

\subsubsection{Aceria sp. n. (Acari: Eriophyoidea: Eriophyidae: Eriophyinae: Aceriini)}

\subsubsection{Sintomatologia}

Em altas infestações, a gema apical de mudas de S. macrophylla foi completamente atacada (Figura 1 - A), causando necrose das folhas antes do seu completo desenvolvimento, superbrotação e bifurcação do fuste (Figura 1 - B). Nas folhas, os ácaros foram encontrados principalmente na parte abaxial e próximo às nervuras. Os primeiros sintomas foliares foram observados com o amarelecimento das nervuras e a presença de pontos despigmentados no tecido adjacente (Figura 1 - C). Em seguida, houve redução do limbo foliar (Figura 1 - D), encarquilhamento, seca e, ocasionalmente, queda das folhas. Os resultados corroboram com Morais \& Flecthmann (2008), onde os autores relatam que os maiores danos causados por ácaros Eriophyidae se concentram na região apical das plantas, com retardamento do seu crescimento devido à redução do comprimento dos internódios. 

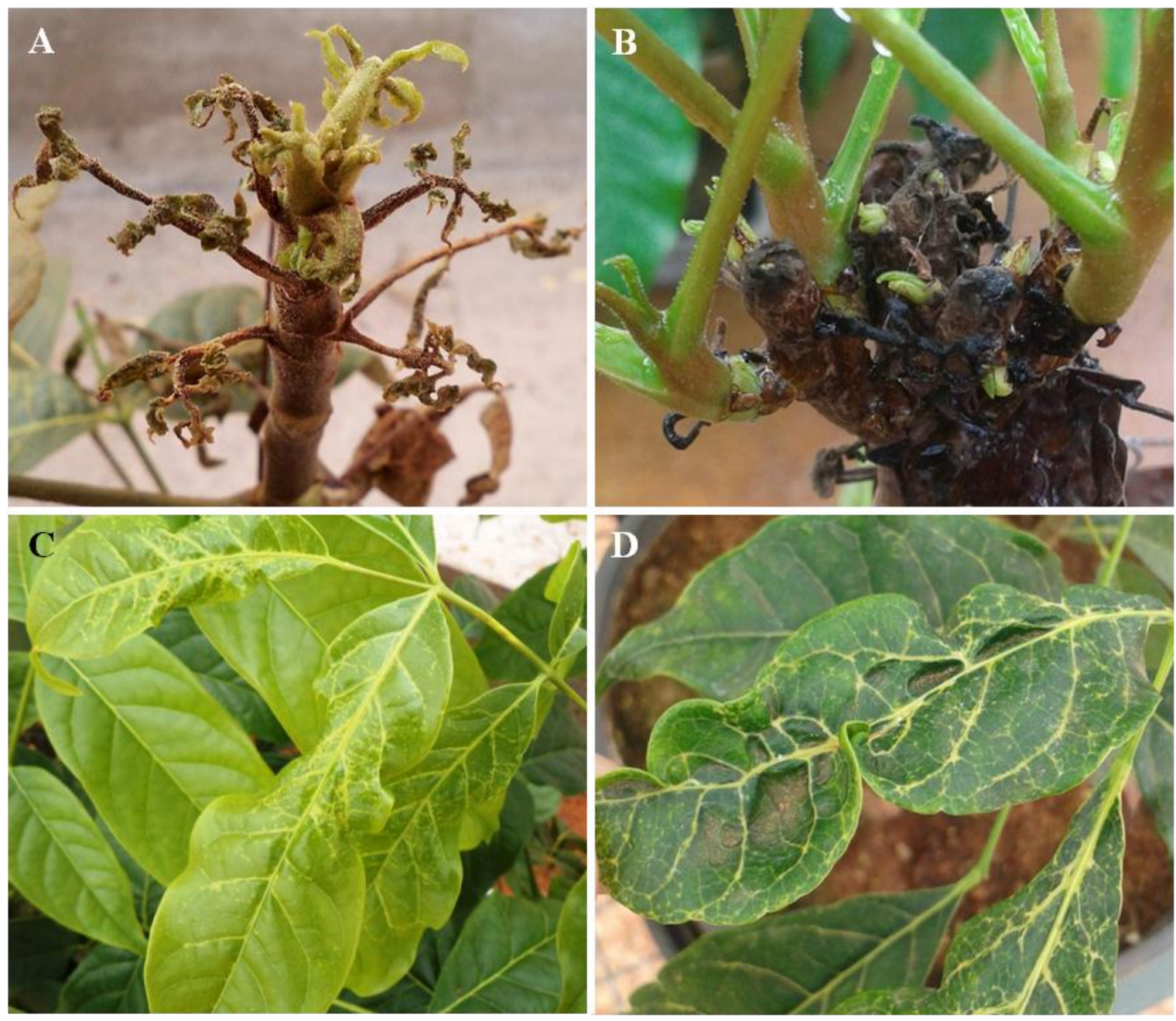

Figura 1 (A - D). Infestação de uma nova espécie de Aceria em mogno. A - Broto terminal atacado. B - Superbrotamento. C - Amarelecimento das nervuras. D - Encarquilhamento foliar.

\subsubsection{Descrição}

FÊMEA - (Figura 2 - D e V / Figura 3 - B e C) [medidas do holótipo e variação de 9 parátipos] - Corpo fusiforme, 180 (169-243) de comprimento e 72 (60-76) de largura, coloração esbranquiçada a amarelada, com pequenas camadas de cera. Gnatossoma com rostro de 22 (21-24) de comprimento, seta apical $(d)$ com 10,5 (7-11) de comprimento e seta basal (ep) com 2 (1,5-4) de comprimento; queliceras com 22 (16-23) de comprimento; estiletes orais com $11(10-11,5)$ de comprimento. Escudo prodorsal 37 (35-40) de 
comprimento, 55 (53-66) de largura; Seta escapular (sc) com 5 (5-6) de comprimento, seta tubercular ( $s p$ ) com 30 (28-32) de comprimento; lobo frontal com 4 (4-5) de comprimento e 12 (11-13) de largura. Pernas I com 26 (23-31) de comprimento; fêmur com 10 (10-12) de comprimento; seta femural $(b v) \mathrm{cm} 11$ (7-11) de comprimento; genu com 5 (4-6) de comprimento; seta do genu (l') com 24 (14-24) de comprimento; tíbia com 9 (8-9) de comprimento; seta da tíbia (l') com 4 (4-5) de comprimento; tarso com 6 de comprimento; seta lateral (ft") com 19 (12-22) de comprimento; seta dorsal (ft') com 13 (12-18) de comprimento; seta unguinal ( $u^{\prime}$ ) com 5 de comprimento; solenídio com 6,5 (6-7) de comprimento, empódio com 7 de comprimento com 4 raios. Pernas II com 29 (26-29) de comprimento; fêmur com 10 (10-12) de comprimento, seta femural (bv) com 15 (8-16) de comprimento; genu com 5 (4-6) de comprimento, seta do genu (l") com 8 (4-9) de comprimento; tíbia com 8 (7-8) de comprimento; tarso com 6 (5-7) de comprimento; seta lateral (ft') com 13 (13-20) de comprimento; seta dorsal (ft') com 4 (4-5) de comprimento; seta unguinal ( $\left.u^{\prime}\right)$ com 2,5 (2-3) de comprimento; solenídio com 7 (6-7,5) de comprimento; empódio com 6 (6-7) de comprimento e 4 raios. Coxa com setas coxais I (1b) separadas entre si por 18 (16-19), com 6 (5-9) de comprimento; setas coxais II (1a) separadas por 8 (6-9), com 20 (15-22) de comprimento; setas coxais III (2a) separadas por 29 (26-30), com 28 (24-35) de comprimento. Linha esternal com 9 (8-9) de comprimento. Região coxigenital com 6 (6-7) anéis. Genitália com linhas curtas e esparsas, com 22 (21-23) de largura e 19 (15-21) de comprimento, com 10 (10-13) estrias longitudinais; seta genital (3a) com 11 (7-11) de comprimento. Microtubérculos pequenos, nas margens dos anéis ventrais. Seta dorsal (cl) ausente; Seta lateral $(c 2)$ com 14 (11-16) de comprimento, no anel 4 (4-7); seta ventral I $(d)$ com 57 (39-68) de comprimento, no anel 14 (14-20), distanciadas por 39 (33-41) e por 15 (12-18) microtubérculos; seta ventral II (e) com 6 (5-7) de comprimento, no anel 29 (29-39), distanciadas por 26 (23-27) e por 8 (6-8) microtubérculos; seta ventral III $(f)$ com 20 (18-22) 
de comprimento, no anel 54 (54-64), separadas por 26 (23-28) e por 15 (14-16) microtubérculos. Total de anéis dorsais 53 (51-56), total de anéis ventrais 60 (60-69). Seta caudal (h2) com 32 (32-69) de comprimento; seta acessória com 1 de comprimento.

MACHO - (Figura 2 - M / Figura 3 - A) [medidas de 5 parátipos] - Menor que a fêmea, com 146 (151-156) de comprimento e 51 (59-59) de largura. Gnatossoma com rostro de 23 (21-24) de comprimento, seta apical $(d)$ com 9 (6-10) de comprimento e seta basal (ep) com 3 de comprimento; queliceras com 19 (21-21) de comprimento; estiletes orais com 10 (11-11) de comprimento. Escudo prodorsal 28 (30-30) de comprimento, 50 (51-52) de largura; Seta escapular (sc) com 4 de comprimento, seta tubercular ( $s p$ ) com 29 (27-31) de comprimento; lobo frontal com 4 (4-4,5) de comprimento e 10 (11-11) de largura. Pernas I com 29 (28-32) de comprimento, ligeiramente maiores que a da fêmea; fêmur com 10 (10-11) de comprimento; seta femural $(b v)$ cm 10 (9-13) de comprimento; genu com 4 de comprimento; seta do genu (l') com 22 (17-22) de comprimento; tíbia com 9 (7-9) de comprimento; seta da tíbia (l') com 5 (5-6) de comprimento; tarso com 6 (6-7) de comprimento; seta lateral ( $\left.f t^{\prime \prime}\right)$ com 18 (13-20) de comprimento; seta dorsal (ft') com 17 (12-17) de comprimento; seta unguinal ( $\left.u^{\prime}\right)$ com 5 (4-5) de comprimento; solenídio com 6 (5-6) de comprimento, empódio com 6 de comprimento com 4 raios. Pernas II com 27 (26-28) de comprimento; fêmur com 10 (11-11) de comprimento, seta femural (bv) com 13 (10-14) de comprimento; genu com 4 de comprimento, seta do genu (l') com 6 (4-6) de comprimento; tíbia com 7 de comprimento; tarso com 7 (7-7,5) de comprimento; seta lateral ( $\left.f t^{\prime \prime}\right)$ com 22 (19-22) de comprimento; seta dorsal (ft') com 5 (4-5) de comprimento; seta unguinal (u') com 3 (3-4) de comprimento; solenídio com 6 (6-7) de comprimento; empódio com 6 (6-7) de comprimento e 4 raios. Coxa com setas coxais I (1b) separadas entre si por 15 (12-16), com 4 (3-4) de comprimento; setas coxais II (1a) separadas por 7 (7-8), com 12 (8-12) de comprimento; setas coxais III (2a) 
separadas por 24 (22-25), com 20 (16-20) de comprimento. Linha esternal com 8 (7-8) de comprimento. Região coxigenital com 6 (6-9) anéis. Genitália com 13 (13-16) de largura e 12 (11-13) de comprimento; seta genital (3a) com 6 (5-6) de comprimento. Microtubérculos pequenos, nas margens dos anéis ventrais. Seta dorsal $(c 1)$ ausente; Seta lateral $(c 2)$ com 12 (10-13) de comprimento, no anel 4 (4-5); seta ventral I (d) com 32 (32-40) de comprimento, no anel 15 (14-16), distanciadas por 30 (28-30) e por 15 (13-15) microtubérculos; seta ventral II (e) com 5 (5-6) de comprimento, no anel 28 (27-29), distanciadas por 15 (14-16) e por 7 (68) microtubérculos; seta ventral III (f) com 18 (16-20) de comprimento, no anel 53 (51-54), separadas por 22 (21-22) e por 12 (12-14) microtubérculos. Total de anéis dorsais 50 (50-52), total de anéis ventrais 59 (57-60). Seta caudal (h2) com 45 (41-55) de comprimento; seta acessória com 1 de comprimento.

IMATURO - (Figura 2 - ID e IV) [Medidas de 5 parátipos] - Corpo com 125 (119-132) de comprimento e 46 (42-47) de largura, sem presença de cera. Gnatossoma com rostro de 19 (19-21) de comprimento, seta apical (d) com 2 (2-4) de comprimento e seta basal (ep) com 1 de comprimento; queliceras com 18 (16-20) de comprimento; estiletes orais com 9 (8-9) de comprimento. Escudo prodorsal 29 (27-33) de comprimento, 42 (39-43) de largura; Seta escapular (sc) com 3 (3-4) de comprimento, seta tubercular (sp) com 20 (19-22) de comprimento; lobo frontal com 3 de comprimento e 10 (9-10) de largura. Pernas I com 19 (18-22) de comprimento; fêmur com 8 (8-9) de comprimento; seta femural (bv) ausente; genu com 4 de comprimento; seta do genu (l’) com 13 (10-14) de comprimento; tíbia com 5 (5-7) de comprimento; seta da tíbia (l') com 3 de comprimento; tarso com 5 (4-6) de comprimento; seta lateral (ft') com 10 (9-10) de comprimento; seta dorsal (ft') com 8 (8-9) de comprimento; seta unguinal ( $\left.u^{\prime}\right)$ com 2 (2-3) de comprimento; solenídio com 5 de comprimento, empódio com 4 (4-5) de comprimento com 4 raios. Pernas II com 18 (17-20) de comprimento; fêmur 
com 7 (7-8) de comprimento, seta femural (bv) com 5 (4-7) de comprimento; genu com 3 (34) de comprimento, seta do genu (l") com 4 (4-6) de comprimento; tíbia com 4 de comprimento; tarso com 5 (5-6) de comprimento; seta lateral (ft') com 11 (9-14) de comprimento; seta dorsal ( $\left.f t^{\prime}\right)$ com 3 (3-4) de comprimento; seta unguinal ( $\left.u^{\prime}\right)$ com 2 de comprimento; solenídio com 5 (5-6) de comprimento; empódio com 4 de comprimento e 4 raios. Coxa com setas coxais I ( $1 b)$ separadas entre si por 13 (10-14), com 3 de comprimento; setas coxais II ( $1 a$ ) separadas por 5 (5-6), com 13 (7-15) de comprimento; setas coxais III (2a) separadas por 22 (20-23), com 18 (12-18) de comprimento. Linha esternal não visível. Região coxigenital sem anéis. Genitália não aparente; seta genital (3a) com 4 (3-5) de comprimento. Microtubérculos pequenos e pouco numerosos. Seta dorsal $(c 1)$ ausente; Seta lateral $(c 2)$ com 6 (6-8) de comprimento, no anel 4; seta ventral I (d) com 25 (25-32) de comprimento, no anel 14 (13-15), distanciadas por 24 (24-26) e por 10 (9-12) microtubérculos; seta ventral II (e) com 4 (4-5) de comprimento, no anel 27 (27-28), distanciadas por 14 (14-18) e por 7 microtubérculos; seta ventral III $(f)$ com 12 (11-15) de comprimento, no anel 44 (43-48), separadas por 19 (19-20) e por 11 (10-11) microtubérculos. Total de anéis dorsais 48 (46-48), total de anéis ventrais 49 (49-51). Seta caudal (h2) com 25 (21-35) de comprimento; seta acessória com 1 de comprimento.

MATERIAL TIPO - Holótipo fêmea, 62 parátipos fêmeas, 36 parátipos machos e 6 parátipos imaturos em 18 preparações microscópicas, em março a setembro de 2014; de Swietenia macrophylla (Meliaceae), Asa Norte, Brasília, Distrito Federal, Brasil, coletados por Marcelo Tavares de Castro, depositados na Coleção de Referência de Ácaros do Laboratório de Quarentena Vegetal, Embrapa Recursos Genéticos e Biotecnologia, Brasília. 


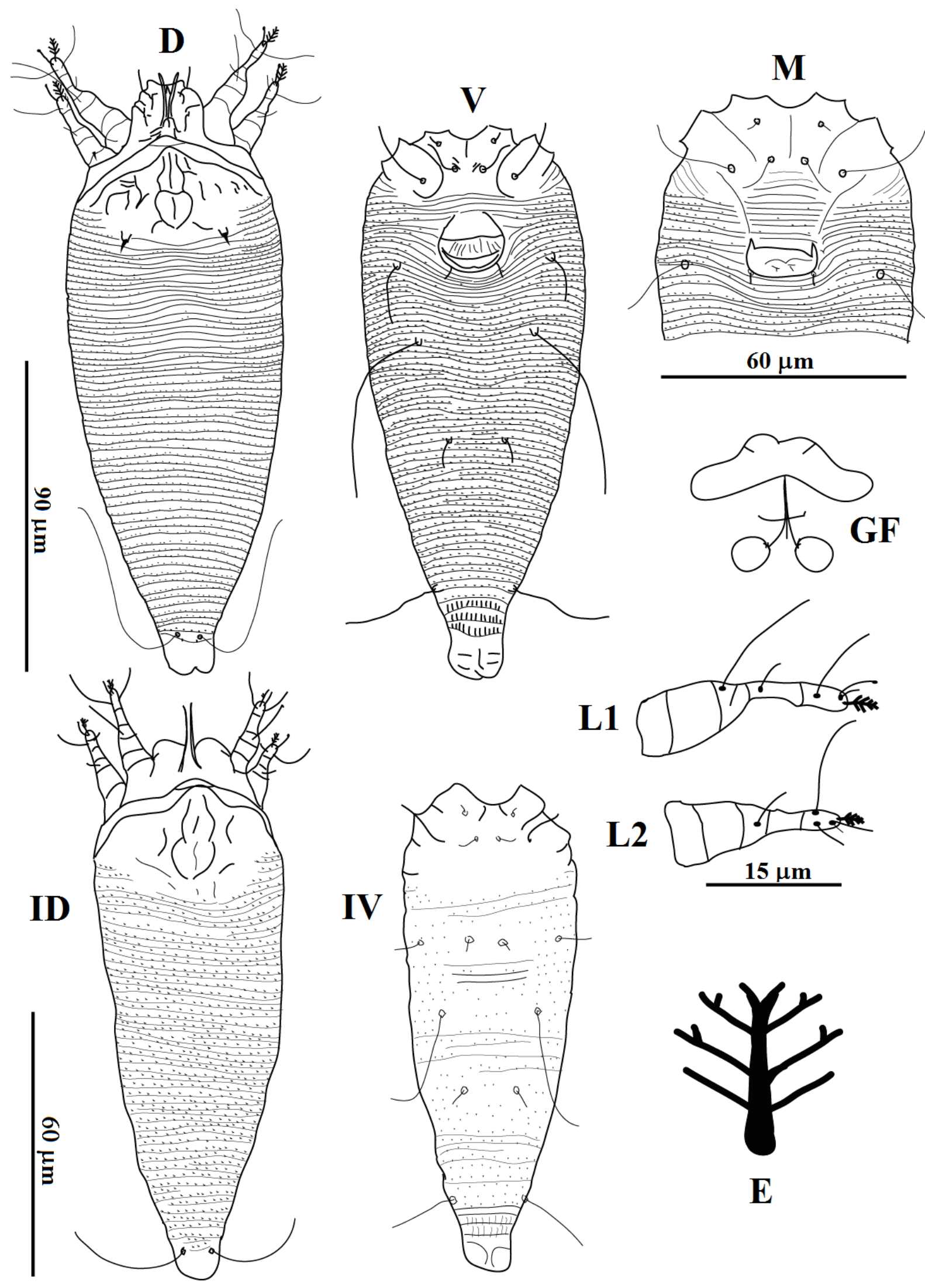

Figura 2. Espécie nova de Aceria em mogno. D: Fêmea dorsal. V: Fêmea ventral. M:

Macho. ID: Imaturo dorsal. IV: Imaturo ventral. L1: Perna 1. L2. Perna 2. E: Empódio. 


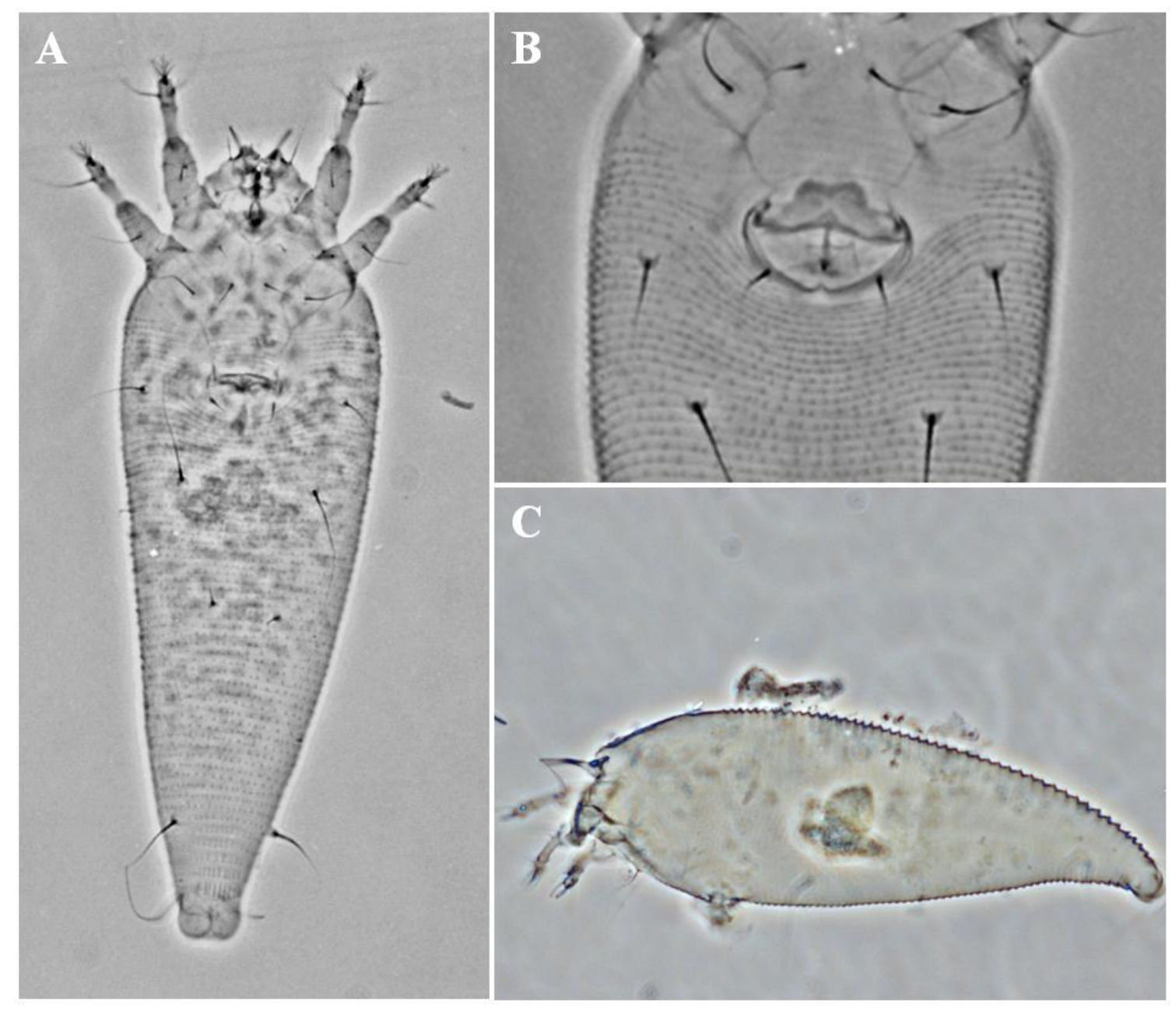

Figura 3 (A - C). Microscopia de Aceria sp. n. encontrado em mogno. A - Macho. B Fêmea. C - Fêmea lateral.

\subsubsection{Comentários}

A maioria das espécies de ácaros eriofídeos é hospedeiro-específico e ocorrem em vários tipos de plantas (Oldfield, 1996). Até o momento, apenas uma espécie do gênero Aceria foi descrita associada a uma espécie da família Meliaceae, Aceria meliae (Dong \& Xin) em Melia azedarach L. (Smith et al., 2010) Estudos mais aprofundados estão sendo realizados com o propósito de definir precisamente a posição taxonômica do presente ácaro, porém, certamente esta é a primeira espécie de ácaro Eriophyidae relatada infestando mogno 
no mundo. Essa espécie foi encontrada também nas árvores de mogno utilizadas na ornamentação de Brasília/DF, causando os mesmos sintomas observados nas mudas.

\subsubsection{Eutetranychus banksi (McGregor) (Acari: Tetranychidae: Tetranychinae)}

\subsubsection{Sintomatologia}

Foram encontrados ácaros principalmente na parte adaxial da folha. $\mathrm{O}$ principal dano causado por esses ácaros consiste no bronzeamento foliar, com pontos cloróticos e com o aspecto prateado, devido à grande quantidade de exúvias (Figura 4). Em ataques intensos, algumas folhas caíram. Os sintomas foram mais observados na porção inferior das mudas, sobretudo nas folhas mais velhas.
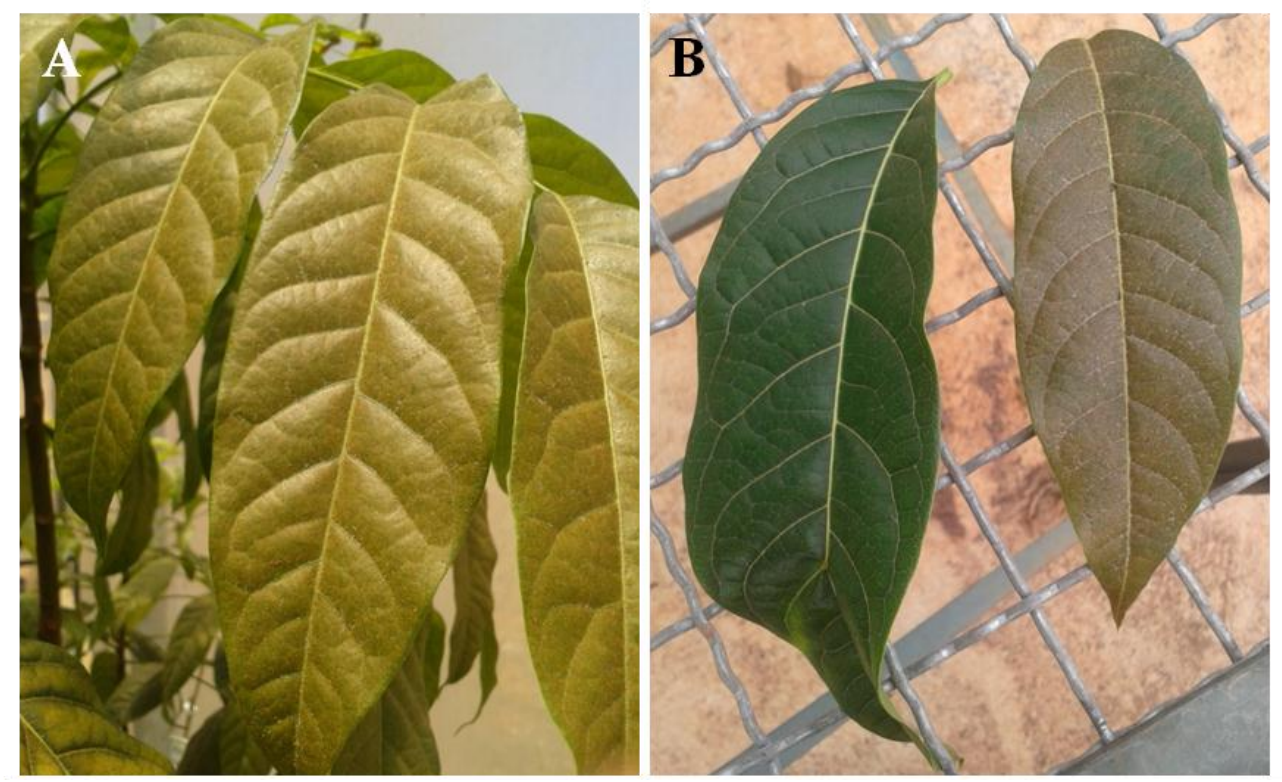

Figura 4 (A e B). Sintomas de Eutetranychus banksi em folhas de mogno. A Amarelecimento e bronzeamento foliar causado pelo ataque de E. banksi . B - Comparação entre uma folha sadia e uma folha atacada. 
6.5.2.2 Descrição [baseada na descrição original feita por McGregor (1914, 1935 e 1950)]

Os ovos da espécie são planos e em formato de disco com uma fina borda em volta. Variam em coloração de amarelo claro a levemente verde. As ninfas são muito parecidas com as fêmeas no formato e na coloração. As fêmeas são largas, robustas e achatadas, com pernas moderadamente fortes (Figura 5 - A). A coloração varia de verde-amarronzada a marrom escuro, com pontos e listras esverdeadas a marrons perto das margens laterais do corpo. As pernas são pálidas a alaranjadas, com segmentos basais bronzeados a marrons. Os machos possuem o corpo com formato triangular e são menores que as fêmeas (Figura 5 - B), com as pernas um pouco maiores. Variam em coloração de bronzeado a marrom claro com pontos e listras escuras a esverdeadas na lateral marginal do corpo. As pernas são levemente bronzeadas.

Eutetranychus banksi apresenta uma elevada variação morfológica entre populações e hospedeiros, o que leva, muitas vezes, a identificações errôneas. Além disso, podem ocorrer também variações numa mesma população, principalmente em relação ao comprimento e a forma das setas dorsais (Muma et al., 1953; Pritchard \& Baker, 1955; Flechtmann \& Baker, 1975), sendo, assim, considerada uma espécie politípica.
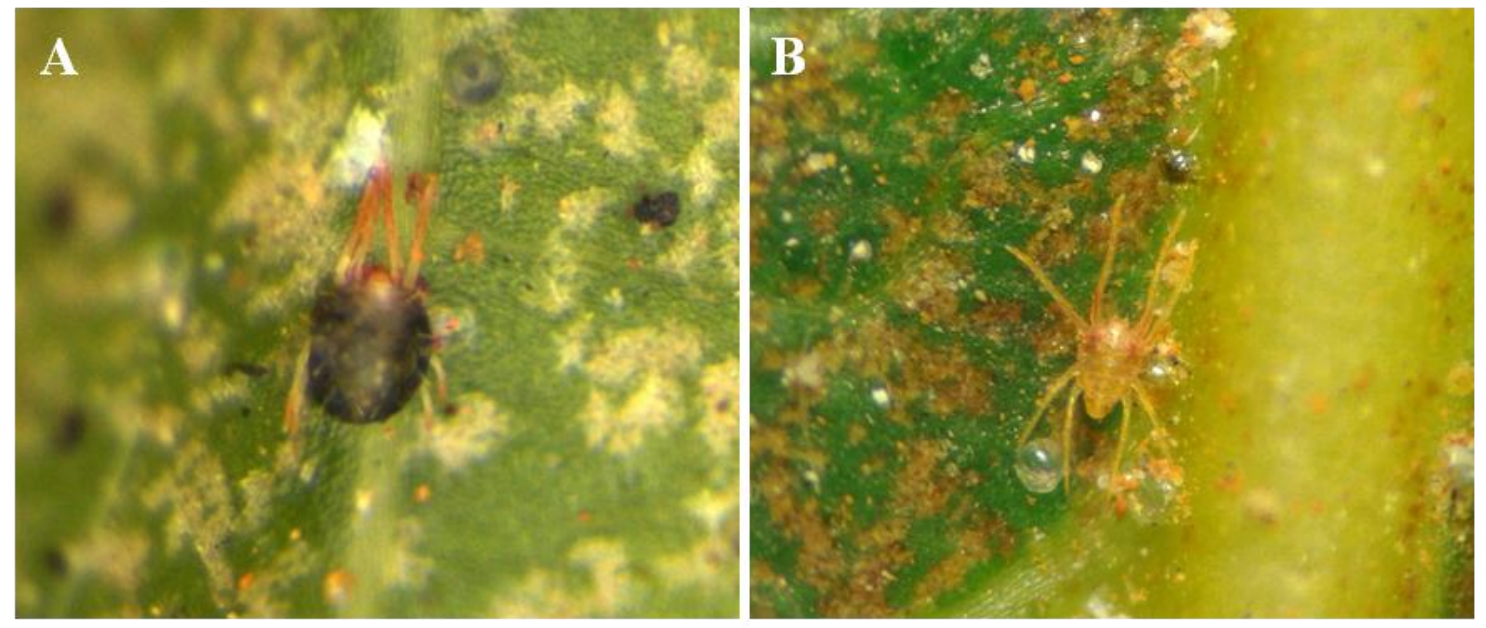

Figura 5 (A e B). Adultos de Eutetranychus banksi em folhas de mogno. A - Fêmea; B Macho. 


\subsubsection{Comentários}

O gênero Eutetranychus contém mais de 30 espécies descritas e cerca da metade dessas espécies tem sido reportada em apenas uma espécie de planta (Migeon \& Dorkeld, 2006). A maioria das espécies descritas foi encontrada em plantas das famílias Fabaceae, Malvaceae, Rutaceae e Moraceae (EFSA, 2013). A espécie Eutetranychus banksi foi descrita por McGregor (1914) em Orlando, Estados Unidos da América associada a dois hospedeiros Ricinus communis L. (Euphobiaceae) e Mucuna pruriens (L.) D. C. (Leguminosae). No Brasil, a espécie foi encontrada pela primeira vez em citrus, na Bahia (Bondar, 1928). Atualmente, já está distribuída em mais de 20 países e em 109 hospedeiros (Migeon \& Dorkeld, 2006).

Esse ácaro é considerado uma praga séria na cultura de citros nos Estados Unidos da América (Jeppson et al., 1975) e no México (Landeros et al., 2004). Já foi registrado em um grande número de hospedeiros no Brasil, causando amarelecimento foliar ou sem causar danos aparentes (Bondar, 1928; Flechtmann \& Abreu, 1973; Feres, 2000; Ferla \& Moraes, 2002; Ferla et al., 2005; Feres et al., 2009). Em membros da família Meliaceae, E. banksi já foi encontrado em Azadirachta indica A. Juss, Cedrela odorata L. em Cuba (Livshtis \& Salinas-Croche, 1968), Cipadessa baccifera (Roth) Miq., Melia azedarach L. no Brasil (Aranda \& Flechtmann, 1971), Trichilia casaretti C. DC. no Brasil (Demite et al., 2013) e Trichilia pallida Swartz em Cuba (Livshits \& Salinas-Croche, 1968). Portanto, essa espécie de ácaro é pela primeira vez relatada em S. macrophylla no mundo.

\subsection{CONCLUSÃO}

- Duas espécies de ácaros, Aceria sp. nova e Eutetranychus banksi, foram observadas e descritas pela primeira vez em mogno. 


\subsection{REFERÊNCIAS BIBLIOGRÁFICAS}

AMRINE, J. W.; MANSON, D. C. M. 1996. Preparation, mounting and descriptive study of eriophyoid mites. In: LINDQUIST, E. E.; SABELIS, M. W.; BRUIN, J. (Ed.) Eriophyoid mites: their biology, natural enemies and control. Amsterdam: Elsevier, p. 383-396.

AMRINE, J. W. JR.; STASNY, T. A.; FLECHTMANN, C. H. W. 2003. Revised keys to world genera of Eriophyoidea (Acari: Prostigmata). Indira Publishing House, West Bloomfield, Michigan, U.S.A., 244 p.

ARANDA, C. B. R.; FLECHTMANN, C. H. W. 1969. Ácaros do gênero Lorryia no Brasil e Paraguay. Anais da II Reunião da Sociedade Brasileira de Entomologia, p. 41-42.

BONDAR,G. 1928. Relatório. Boletim do Laboratório de Patologia Vegetal, v. 4, p. 39-46.

CARVALHO, P. E. R. 2007. Mogno - Swietenia macrophylla. Colombo, Paraná, Embrapa Florestas. Circular Técnico 140, p. 12.

DE LILlO, E.; DI PALMA, A.; NUZZACI, G. 2002. Morphological adaptations of mite chelicerae to different trophic activities (Acari). Entomologica, v. 35, p. 125-180.

DE LILLO, E.; MONFREDA, R. 2004. 'Salivary secretions' of eriphyoids (Acari: Eriophyoidea): first results of an experimental model. Experimental and Applied Acarology, v. 34, p. 291-306. 
DE LILlO, E.; CRAEMER, C.; AMRINE, J. W. JR.; NUZZACI, G. 2010. Recommended procedures and techniques for morphological studies of Eriophyoidea (Acari: Prostigmata). Experimental and Applied Acarology, v. 51, n. 1-3, p. 283-307.

DEMITE, P. R.; LOFEGO, A. C.; FERES, R. J. F. 2013. Mite (Acari: Arachnida) diversity of two native plants in fragments of a semideciduous seasonal forest in Brazil. Systematics and Biodiversity, v. 11, p. 141-148.

EUROPEAN FOOD SAFETY AUTHORITY (EFSA). 2013. Scientific Opinion on the risk to plant health posed by Eutetranychus orientalis Klein in the EU territory, with the identification and evaluation of risk reduction options. EFSA Journal, v. 11, n. 7, 81 p.

FERLA, N. J.; MORAES, G. J. 2002. Ácaros (Arachnida, Acari) da seringueira (Hevea brasiliensis Muell. Arg.) no Estado do Mato Grosso, Brasil. Revista Brasileira de Zoologia, n. 19, p. $867-888$.

FERLA, N. J.; MARCHETTI, M. M.; SIEBERT, J. C. 2005. Acarofauna (Acari) de ervamate (Ilex paraguariensis St. Hil.: Aquifoliaceae) no Estado do Rio Grande do Sul. Biociências, n. 13, p. 133-142.

FERES, R. J. F. 2000. Levantamento e observações naturalísticas da acarofauna (Acari: Arachnida) de seringueiras cultivadas (Hevea spp., Euphorbiaceae) no Brasil. Revista Brasileira de Zoologia, v. 17, p. 157-173. 
FERES, R. J. F.; VIEIRA, M. R.; DAUD, R. D.; PEREIRA JR, E. G.; OLIVEIRA, G. F.; DOURADO, C. L. 2009. Ácaros (Arachnida, Acari) de plantas ornamentais na região noroeste do Estado de São Paulo, Brasil: inventário e descrição dos sintomas causados pelos fitófagos. Revista Brasileira de Entomologia, v. 53, n. 3, p. 466-474.

FLECHTMAN, C. H. W.; ABREU, J. M. 1973. Ácaros fitófagos do Estado da Bahia, Brasil. Ciência e Cultura, n. 25, p. 244-251.

FLECHTMANN, C. H. W.; BAKER, E. W. 1975. A report on the Tetranychidae (Acari) of Brazil. Revista Brasileira de Entomologia, v. 19, p. 111-122.

GUEDeS, R. N. C.; OMOTO, C. 2000. Resistência de Pragas a Pesticidas: Princípios e Práticas. IRAC-BR. Petrolina, 26 p.

HUANG, K. W. 2008. Aceria (Acarina: Eriophyoidea) in Taiwan: Five new species and plant abnormalities caused by sixteen species. Zootaxa, v. 1829, p. 1-30.

JEPPSON, L. R.; KEIFER, H. H.; BAKER, E. W. 1975. Mites injurius to economic plants. Los Angeles, University California Press, 614 p.

LANDEROS, L.; CERNA, E.; BADII, M. H.; VARELA, S.; FLORES, A. E. 2004. Patrón de distribuición espacial y fluctuación poblacional de Eutetranychus banksi (McGregor) y su depredador Euseius mesembrinus (Dean) (Acari: Tetranychidae, Phytoseiidae) em uma huerta de naranjos. Acta Zoológica Mexicana, v. 20, p. 147-155. 
LINDQUIST, E. E. 1985. Chapter 1.1 Anatomy, phylogeny and systematic. 1.1.1 External anatomy. In: HELLE, W.; SABELIS, M. W. (Eds) Spider Mites. Their Biology, Natural Enemies and Control. Volume 1A. Amsterdam, Elsevier, p. 3-28.

LINDQUIST, E. E.; SABELIS, M. W.; BRUIN, J. 1996. Eriophyoid mites: their biology, natural enemies and control. Elsevier: Amsterdam, 790 p.

LIVSHITS, I. Z.; SALINAS-CROCHE, A. 1968. Preliminares acerca de los acaros "Tetranicos" de Cuba. Centro National de Fitosanidad, 156 p.

MCGREGOR, E. A. 1914. Four new Tetranychids. Annals of the Entomological Society of America, v. 7, n. 4, p. 354-364.

MCGREGOR, E. A. 1935. The Texas citrus mite, a new species. Proceedings of the Entomological Society of Washington, v. 37, n. 8, p. 161-165.

MCGREGOR, E. A. 1950. Mites of the family Tetranychidae. The American Midland Naturalist Journal, v. 44, n. 2, p. 257-420.

MIGEON, A.; DORKELD, F. 2006. Spider Mites Web: a comprehensive database for the Tetranychidae. <http://www1.montpellier.inra.fr/CBGP/spmweb>. Acesso em 18/01/2016.

MORAES, G. J.; FLECHTMANN, C. H. W. 1981. Ácaros fitófagos do Brasil. Pesquisa Agropecuária Brasileira, v. 16, p. 177-186. 
MORAES, G. J.; FLEChtMANN, C. H. W. 2008. Manual de Acarologia: Acarologia Básica e Ácaros de Plantas Cultivadas no Brasil. Ribeirão Preto: Holos Editora, 308 p.

MUMA, M. H.; HOLTZBERG, H.; PRATT, R. M. 1953. Eutetranychus banksi (McGregor) recently found on citrus in Florida (Acarina: Tetranychidae). Florida Entomologist, v. 4, p. $141-144$.

OLDFIELD, G. N. 1996. Diversity and host plant specificity. In: LINDQUIST, E.E.; SABELIS, M. W.; BRUIN, J. (Ed.). Eriophyoid mites: their biology, natural enemies and control. Amsterdam, Elsevier, p. 199-216.

PETANOVIC, R.; KIELKIEWICZ, M.; 2010a. Plant-eriophyoid mite interactions: cellular biochemistry and metabolic responses induced in mite-injured plants. Part I. Experimental and Applied Acarology, v. 51, n. 1-3, p. 61-80.

PETANOVIC, R.; KIELKIEWICZ, M. 2010b. Plant-eriophyoid mite interactions: specific and unspecific morphological alterations. Part II. Experimental and Applied Acarology, v. 51, n. 1-3, p. 81-91.

PRITCHARD, A. E.; BAKER, E. W. 1955. A revision of spider mite family Tetranychidae. San Francisco: Pacific Coast Entomological Society (Memoirs Series, v. 2), $472 \mathrm{p}$.

SHORACKA, A.; SMITH, L.; OLDFIELD, G.; CRISTOFARO, M.; AMRINE, J. W. 2010. Host-plant specificity and specialization in eriophyoid mites and their importance for the use 
of eriophyoid mites as biocontrol agents of weed. Systematic and Applied Acarology, v. 51, n. 1-3, p. 93-113.

SMITH, L.; LILLO, E.; AMRINE JR, J. W. 2010. Effectiveness of eriophyid mites for biological control of weedy plants and challenges for future research. Experimental and Applied Acarology, v. 51, p. 115-149.

VAN LEEUEWN, T.; WITTERS, J.; NAUEN, R.; DUSO, C.; TIRRY, L. 2010. The control of eriophyoid mites: state of the art and future challenges. Experimental and Applied Acarology, v. 51, n. 1-3, p. 205-224. 


\section{CAPÍTULO 7}

\section{ANÁLISE DA OCORRÊNCIA DE FUNGOS EM SEMENTES DE MOGNO (Swietenia macrophylla King) COLETADAS EM BRASÍLIA, DISTRITO FEDERAL}

\subsection{RESUMO}

Estudos relacionados à ocorrência e identificação de fungos em sementes florestais e sua transmissão para as plântulas no Brasil são, ainda, muito incipientes. Assim, este trabalho teve como objetivo identificar os fungos associados a sementes de mogno (Swietenia macrophylla King) coletadas no Distrito Federal. Para o Blotter-test, foram usadas 192 sementes de mogno desinfestadas e para o método do sintoma em plântulas foram plantadas 120 sementes. Como resultado, aproximadamente 14\% (27) das sementes apresentaram sinais de fungos, tanto quando analisadas pelo Blotter-test ou no teste em plântulas. A grande maioria dos fungos identificados são saprófitas, no entanto, o fungo potencialmente fitopatogênico, Fusarium oxysporum Schltdl. foi observado também nos dois testes. A inoculação artificial de sementes de mogno com $F$. oxysporum demonstrou que este foi patogênico, causando redução na germinação de sementes (75\%) e morte de plântulas (100\%). Este é o primeiro trabalho no Brasil que descreve a capacidade patogênica de $F$. oxysporum em sementes de mogno. Palavras-chave: patologia florestal, análise de sementes, fungos em sementes. 


\section{ANALYSIS OF THE OCCURRENCE OF FUNGI ON MAHOGANY SEEDS (Swietenia macrophylla King) COLLECTED IN BRASÍLIA, BRAZIL}

\subsection{ABSTRACT}

Studies related to fungal occurrence and identification of fungi in forest seeds and its transmission to seedlings in Brazil are still very incipient. Therefore, this study aimed to identify the fungi found in mahogany seeds (Swietenia macrophylla King) collected from trees located in Distrito Federal. For the blotter-test were used 192 disinfected mahogany seeds. In the method of seedling symptom it was planted 120 mahogany seeds. As a result, approximately 14\% (27) of the seed showed signals of fungi when analyzed by the blotter-test and the method of seedling symptom. The vest majority of fungi are identified are saprophytic, however, the potentially plant pathogenic fungus Fusarium oxysporum Schltdl. was observed in the both tests. The artificial inoculation of $F$. oxysporum in mahogany seeds showed that it was pathogenic, causing a reduction in seed germination (75\%) and death of seedlings $(100 \%)$. This is the first work in Brazil describing the pathogenic capacity of $F$. oxysporum in mahogany seeds.

Keywords: forest pathology, seed analysis, fungi in seeds. 


\subsection{INTRODUÇÃO}

Estudos relacionados à ocorrência e identificação de fungos em sementes florestais e sua transmissão para as plântulas no Brasil são escassos. Os trabalhos em sua maioria são baseados em testes de detecção em sementes, sem a preocupação de verificar a patogenicidade em mudas. Em geral, as pesquisas sobre disseminação de patógenos em espécies florestais estão concentradas na Índia, Canadá, Estados Unidos e África, sendo as coníferas as mais estudadas (Santos et al., 2011).

Os principais fungos associados a sementes florestais, segundo Ferreira (1989), são saprófitas e parasitas facultativos que tem vida saprofítica no solo ou na matéria orgânica, tais como Alternaria sp., Cylindrocladium sp., Fusarium sp., Phoma sp., Phomopsis sp., Pythium sp., Rhizoctonia sp., Trichoderma sp., dentre outros. Fungos do gênero Fusarium são um dos principais patógenos relatados em associação com sementes de espécies florestais. Estes fungos são responsáveis por danos em sementes, afetando sua germinação, ou podem ser transmitido para as mudas, causando podridão radicular e tombamento de plântulas. No Brasil, fungos deste gênero foram descritos em associação com sementes de aproximadamente 100 espécies florestais no Brasil (Santos et al., 2011).

O mogno (Swietenia macrophylla King) é uma espécie de alto valor comercial e sua propagação é feita principalmente por sementes (Yared \& Carpanezzi, 1981). Uma árvore adulta pode até 30 mil sementes por ano e são dispersas pelo vento (Gullison et al., 1996). A qualidade sanitária das sementes é imprescindível para a germinação e o crescimento sadio de mudas.

Considerando a baixa oferta de sementes de mogno e seu alto valor comercial o aproveitamento total das sementes é desejável. As perdas causadas por fungos fitopatogênicos associados à sementes podem ser minimizadas através do tratamento de sementes, no entanto, para se delinear estratégias de controle de fitopatógenos é preciso conhecê-los. Devido à 
escassez desse tipo de estudo com a espécie referida, este trabalho teve como objetivo identificar e caracterizar os fungos encontrados em sementes de mogno coletadas em Brasília, Distrito Federal, assim como avaliar a patogenicidade dos fungos potencialmente fitopatogênicos associados às sementes.

\subsection{MATERIAL E MÉTODOS}

\subsubsection{Procedência das sementes e local de realização dos experimentos}

As sementes de mogno foram coletadas em Brasília, Distrito Federal, durante os meses de outubro a dezembro de 2013 e armazenadas em temperatura ambiente até a realização dos testes de sanidade e semeadura.

Os testes de sanidade das sementes foram realizados no Laboratório de Bactérias Entomopatogênicas da Embrapa Recursos Genéticos e Biotecnologia, situada em Brasília, Distrito Federal. O método do sintoma em plântulas foi conduzido em casa de vegetação, sem controle de umidade e temperatura, durante os meses de janeiro a março de 2014.

\subsubsection{Testes de sanidade}

\subsubsection{Blotter-test}

Foram utilizadas 192 sementes de mogno não desinfestadas, sem a ala, divididas em 12 repetições com 16 sementes cada, dispostas em papel toalha umedecido com água destilada autoclavada e acondicionadas em caixas gerbox previamente desinfestadas com álcool 70\%. O material, então, foi colocado em B.O.D. com temperatura de $25 \pm 2{ }^{\circ} \mathrm{C}$ e fotoperíodo de 12 horas de luz por 12 horas de escuro, por sete dias. Após esse período, cada semente foi analisada e os fungos encontrados foram identificados em nível de gênero ou espécie. 


\subsubsection{Método do sintoma em plântulas}

Foram utilizadas 120 sementes de mogno sem a ala, divididas em dois blocos com 60 sementes cada. O substrato utilizado foi o BioPlant ${ }^{\circledR}$ Prata HT autoclavado [casca de pinus, esterco, serragem, fibra de coco, vermiculita, casca de arroz, cinza, gesso agrícola, carbonato de cálcio, magnésio, termofosfato magnesiano - yoorin - e aditivos - fertilizantes]. As sementes foram semeadas na posição horizontal, com cerca de $1 \mathrm{~cm}$ de profundidade, para facilitar e acelerar a germinação. A avaliação do teste foi feita pela observação da emergência das plântulas, sintomas da doença e sinais do patógeno nas plântulas e nas sementes não germinadas, conforme Santos et al. (2011). As sementes sem sinais de fungos foram colocadas em câmara úmida por sete dias. Os fungos encontrados foram visualizados em microscópio estereoscópio e de luz e identificados em nível de gênero ou espécie.

\subsubsection{Identificação dos fungos}

Os fungos encontrados nas duas metodologias foram isolados em meio BDA e descritos detalhadamente quanto ao seu crescimento por meio da análise visual do micélio, coloração e forma de crescimento. As estruturas fúngicas foram observadas em microscópio estereoscópio (lupa) e de luz, por meio da confecção de lâminas com corantes a base de lactoglicerol / azul de algodão (Cotton-Blue) ou glicerol KOH / floxina básica, as quais foram seladas com duas camadas de esmalte de unha comercial. As descrições morfológicas foram baseadas em atributos a cerca do conidióforo, célula conidiogênica e conídio, para os fungos anamórficos. Para a identificação de cada gênero, foram utilizadas chaves específicas de acordo com as suas características anamórficas. 


\subsubsection{Patogenicidade de Fusarium oxysporum em sementes e mudas de mogno}

Quarenta sementes de mogno foram utilizadas, divididas em dois lotes com 20 sementes cada. Um lote foi utilizado para a inoculação do fungo por contato direto com o micélio o outro para a testemunha. As sementes foram desinfestadas em álcool $70 \%$ por 30 segundos e hipoclorito de sódio $1 \%$ por dois minutos e lavadas com água destilada esterilizada, conforme Santos et al. (2011). As sementes foram colocadas em papel autoclavado para secagem e posteriormente colocadas em contato com a cultura fúngica crescida em meio BDA por 72 horas e então semeadas em substrato BioPlant® Prata HT autoclavado.

Após 30 dias da semeadura, foi contado o número de plântulas com sintomas, o número de plântulas sadias e o número de sementes não germinadas. As plântulas sintomáticas e sementes não germinadas foram colocadas em câmara úmida, por sete dias, para identificação e reisolamento do fungo.

\subsubsection{Identificação molecular de Fusarium oxysporum}

O isolado purificado foi crescido em meio de cultura BDA, em câmara de germinação (BOD) à $25 \pm 0,5{ }^{\circ} \mathrm{C}$ por 10 dias. Foram cortados três discos do meio de cultura contendo o fungo e inoculados em frasco de Erlenmeyer com 200mL de meio líquido SDY (4\% dextrose, $1 \%$ extrato de levedura e $1 \%$ peptona). Após $72 \mathrm{~h}$ de incubação em shaker rotativo a $25 \pm 0,5$ ${ }^{\circ} \mathrm{C}$ e $250 \mathrm{rpm}$, o micélio foi coletado em papel de filtro sob filtração a vácuo e utilizado para a extração de DNA segundo o método descrito por Raeder \& Broda (1985). A região do fator de alongamento foi amplificada e sequenciada de acordo com Renher et al. (2011). A sequência obtida foi editada pelo programa DNA baser (DNABaser Sequence Assembler 3, Heracle Biosoft, Pitesti, Romania) e alinhada com outras sequencias obtidas pelo banco de dados GenBank e do banco de dados do Fusarium ID. 


\subsection{RESULTADOS E DISCUSSÃO}

Quando da análise do Blotter-test, das 192 sementes analisadas, 27 (14,1\%) apresentaram sinais de fungos, conforme Tabela 1 e Figura 1. Muitas sementes apresentaram mais de um fungo em sua superfície. Conforme Carvalho \& Muchovej (1991), a maioria dos fungos encontrados em sementes pertence à subdivisão Deuteromycotina, também conhecidos como fungos conidiais ou hifomicetos.

Tabela 1. Fungos encontrados em sementes de mogno a partir do Blotter-test.

\begin{tabular}{ccc}
\hline Espécie fúngica & Número de sementes / \% & Hábito \\
\hline Penicillium sp. & $9 / 4,7 \%$ & Saprófita \\
Aspergillus spp. & $8 / 4,2 \%$ & Saprófita \\
Rhizopus sp. & $5 / 2,6 \%$ & Saprófita \\
Curvularia sp. & $3 / 1,6 \%$ & Fitopatogênico \\
Fusarium sp. & $2 / 1,1 \%$ & Fitopatogênico \\
\hline
\end{tabular}

Os fungos, em sua maioria, eram saprófitas (81,5\%). Dentre os fungos saprófitas, os gêneros Aspergillus e Penicillium foram os mais abundantes, e o gênero Rhizopus foi observado em menor frequência. Estes fungos são considerados como potenciais infestantes de sementes armazenadas, pois a incidência pode aumentar no período pós-colheita (Christensen, 1973). Carneiro (1990) recomenda o controle desses gêneros quanto à incidência em sementes, pois, a alta porcentagem de infestação tende a reduzir a sua viabilidade e interferir nas condições de armazenamento das mesmas, sendo responsáveis por reduções na viabilidade e longevidade das sementes.

O fungo potencialmente fitopatogênico, da espécie Fusarium oxysporum Schltdl (99,7\% de similaridade - GenBank / Fusarium ID), estava associado a 7,5\% das sementes que apresentaram sinais de fungos. Fusarium oxysporum pode impedir a germinação da semente ou, ainda, ser transmitido para as plantas via sementes, causando problemas radiculares e 
tombamento de plântulas em mudas, conforme observado por Lazarotto et al. (2012) em mudas de cedro.
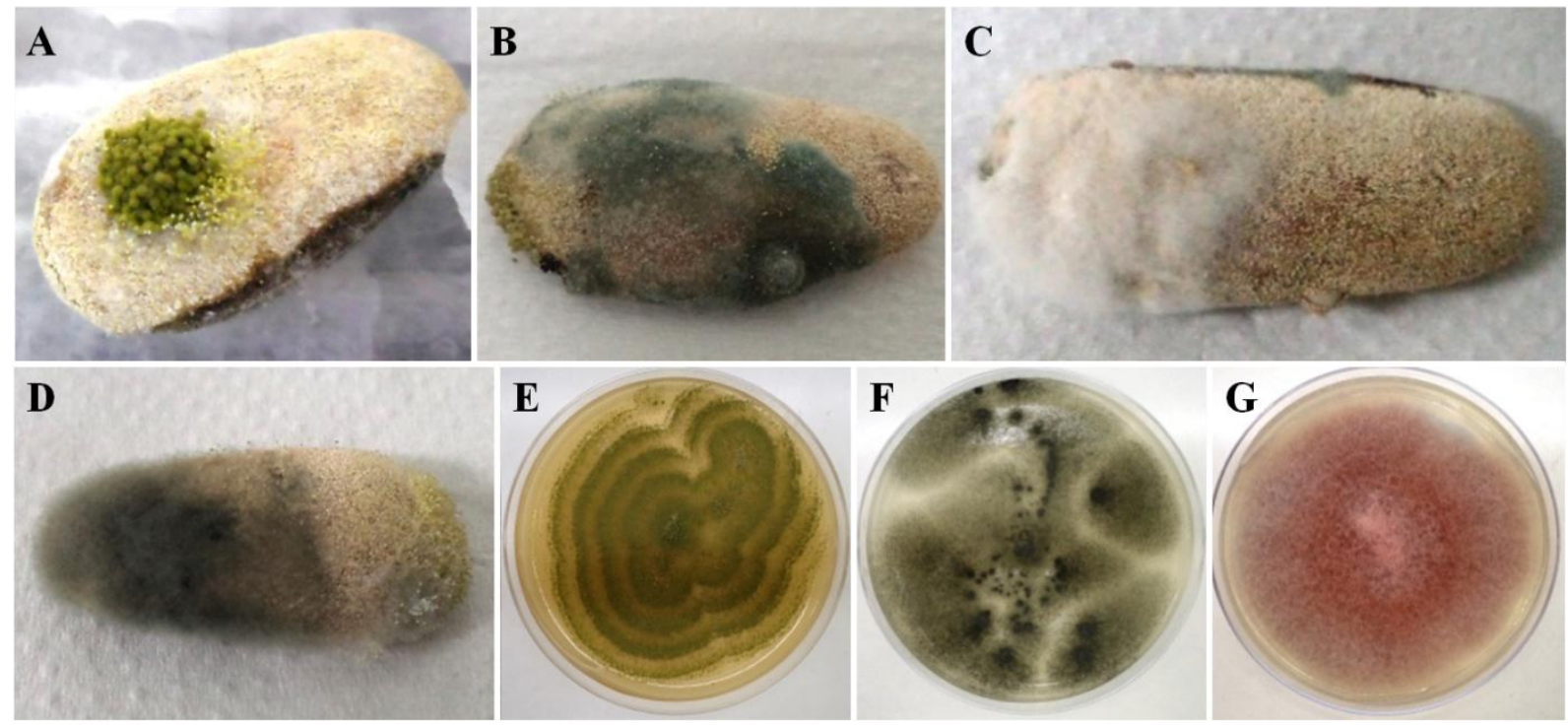

Figura 1 (A - G). Alguns fungos encontrados em sementes de mogno pelo Blotter-test. A Aspergillus flavus. B - Penicillium sp. C - Fusarium oxysporum. D - Curvularia sp. E Colônia de Asperillus flavus em meio BDA. F - Colônia de Aspergillus niger em meio BDA. G - Colônia de Fusarium oxysporum em meio BDA.

A presença do fungo $F$. oxysporum é relatada pela primeira vez em associação com sementes de mogno no Brasil. Stein et al. (1997) examinaram a ocorrência de fungos em sementes desta espécie oriundas da Amazônia. Na ocasião, os autores detectaram os fungos Botryodiplodia sp., Aspergillus spp. e Penicillium spp. No presente estudo, apenas Botryodiplodia sp. não foi encontrado, porém, outros três fungos distintos foram observados, o que demonstra que a ocorrência de fungos associados a sementes desta espécie pode variar entre as regiões.

No método do sintoma em plântulas, das 120 sementes plantadas, 85 germinaram (71\%), 35 não germinaram (29\%). Dentre aquelas que não germinaram, $14(11,6 \%)$ 
apresentaram sintomas e sinais de fungos nas sementes. Foram encontradas três espécies de fungos distintos, Aspergillus flavus Link, Aspergillus niger Tiegh. e F. oxysporum, conforme a Tabela 2. Nenhuma plântula apresentou sintomas.

Tabela 2. Fungos encontrados em sementes de mogno pelo método do sintoma em plântulas.

\begin{tabular}{ccc}
\hline Espécie fúngica & Número de sementes /\% & Hábito \\
\hline Aspergillus spp. & $12 / 10 \%$ & Saprófita \\
Fusarium oxysporum & $2 / 1,6 \%$ & Fitopatogênico \\
\hline
\end{tabular}

Na determinação da patogenicidade do isolado de Fusarium oxysporum oriundo das sementes de mogno, observou-se que, das 20 sementes plantadas inoculadas com o fungo, apenas cinco germinaram, as outras 15 não germinaram e apresentaram sintomas e sinais do fungo, o que indica que o isolado é patogênico. As testemunhas não apresentaram sintomas. Os sintomas causados por $F$. oxysporum nas cinco sementes germinadas e inoculadas com o patógeno foram queima de raízes, lesões no colo da planta, queima de cotilédones e posterior morte da plântula. Este resultado representa o primeiro relato de $F$. oxysporum associado a sementes de mogno, causando redução na germinação das sementes e morte de plântulas.

Os fungos do gênero Fusarium podem se comportar como fitopatogênicos à sementes florestais. Salles (1992) confirmou a patogenicidade de Fusarium sp. em ipê-roxo e barbatimão, na qual o fungo causou redução na germinação e apodrecimento de sementes. Benetti et al. (2009) constataram que isolados de Fusarium e Pestalotia encontrados em sementes de cedro (Cedrella fissilis Vell.) reduziram o poder germinativo após a sua inoculação. As espécies Fusarium moniliforme J. Sheld., F. semitectum Berk \& Ravenel e F. oxysporum foram associadas a sementes de Pinus elliottii Engelm. no Paraná e Santa Catarina, sendo a última causadora de tombamento de plântulas (Homechin et al., 1986) e Fusarium sambucinum Fuckel associado sementes de P. elliotti oriundas do Rio Grande do 
Sul também são transmitidos para plântulas causando anelamento do colo da plântula e podridão de parte aérea (Maciel, 2012). Em coníferas da América do Norte, incluindo o pinus, a maioria dos fungos transmitidos por sementes para plântulas pertencem ao gênero Fusarium (Cram \& Fraedrich, 2010).

De acordo com Dhingra et al. (1980) e Machado (1988), a contaminação por Fusarium ocorre durante a formação ou a maturação do fruto. Os patógenos presentes nas sementes, tanto interna como externamente, tornam-se ativos, tão logo as sementes sejam semeadas em solos úmidos. Estas sementes apodrecem antes mesmo de germinar. Ou o patógeno poderá não atacar a semente, mas infectar a plântula (Dhingra et al., 1980).

\subsection{CONCLUSÕES}

- Fusarium oxysporum foi isolado de sementes de mogno e apresentou potencial de dano em sementes e plântulas;

- Os dois métodos utilizados neste trabalho, quando comparados, mostram que o Blotter-test é mais eficiente para detectar a ocorrência de fungos em sementes de mogno.

\subsection{REFERÊNCIAS BIBLIOGRÁFICAS}

BENETTI, S. C.; SANTOS, A. F.; MEDEIROS, A. C. S.; JACCOUD FILHO, D. S. 2009. Levantamento de fungos em sementes de cedro e avaliação da patogenicidade de Fusarium sp. e Pestalotia sp. Pesquisa Florestal Brasileira, n. 58, p. 79-83.

CARNEIRO, J. S. 1990. Qualidade sanitária de sementes de espécies florestais em Paraopeba, MG. Fitopatologia Brasileira, v.15, p.75-76. 
CARVALHO, W. L. \& MUCHOVEJ, J. J. 1991. Fungos associados a sementes de essências florestais. Revista Árvore, v.15, n.2, p.173-178.

CHRISTENSEN, C. M. 1973. Loss of viability in storage microflora. Seed Science and Technology, Zurich, v. 1, n. 3, p. 547-562.

CRAM, M. M. \& FRAEDRICH, S. W. 2010. Seed diseases and seedborne pathogens of North America. Tree Plant's Notes, v.53, p.35-44.

DHINGRA, O.D.; MUCHOVEJ, J. J.; CRUZ FILHO, J. 1980. Tratamento de sementes (Controle de patógenos). Viçosa: UFV, Imprensa Universitária, 121 p.

FERREIRA, F. A. 1989. Patologia florestal: principais doenças florestais no Brasil. Viçosa: UFV, SIF, 570 p.

GULLISON, R. E.; PANFIL, S. N.; STRUOSE, J. J.; HUBBELL, S. P. 1996. Ecology and management of mahogany (Swietenia macrophylla King) in the Chimanes Forest, Beni, Bolivia. Botanical Journal of the Linnean Society, v. 122, p. 9-34.

HOMECHIN, M.; PIZZIONATTO, M. A.; MENTEN, J. O. M. 1986. Sanidade de sementes de Pinus ellottii var. ellotti e Pinus taeda e patogenicidade de Furasium oxysporum em plântulas de Pinus elliottii var. elliottii. Summa Phytopathologica, v.12, p.103-112.

LAZAROTTO, M.; BRIÃO MUNIZ, M. F.; BELTRAME, R.; DOS SANTOS, A. F.; GONZATTO MACIEL, C.; LONGHI, S. J. 2012. Sanidade, transmissão via semente e 
patogenicidade de fungos em sementes de Cedrella fissilis procedentes da região Sul do Brasil. Ciência Florestal, v. 22, n. 3, p. 493-503.

MACHADO, J. C. 1988. Patologia de sementes: fundamentos e aplicações. Brasília: MEC / ESAL / FAEPE, 106p.

MACIEL, C. G. 2012. Fusarium sambucinum associado a sementes de Pinus elliotti: patogenicidade, morfologia, filogenia molecular e controle. Dissertação (Mestrado em Engenharia Florestal), Universidade Federal de Santa Maria, Santa Maria, 94 f.

SALES, N. L. P. Efeito da população fúngica e do tratamento químico no desempenho de sementes de ipê-amarelo, ipê-roxo e barbatimão. 1992. Dissertação (Mestrado em Fitossanidade) - Universidade Federal de Lavras, $89 \mathrm{f}$.

SANTOS, A. F.; PARISI, J. J. D.; MENTEN, J. O. M. 2011. Patologia de sementes florestais. Colombo: Embrapa Florestas, 236 p.

STEIN, R. L. B.; LEÃO, N. V. M.; CARVALHO, J. E. U. 1997. Health testes on native Amazon Forest tree seeds. In: Procházková Z \& Sutherland JR. Proceedings of the ISTA Tree Seed Pathology Meeting. Opocno: ISTA, p.108-111.

YARED, J. A. G. \& CARPANEZZI, A. A. 1981. Conversão de capoeira alta da Amazônia em povoamento de produção madeireira: o método "recrû" e espécies promissoras. Belém: Embrapa CPATU, 27p. 


\section{CAPÍTULO 8}

\section{NOVOS RELATOS DE FUNGOS FOLIARES EM MOGNO (Swietenia macrophylla King) NO BRASIL}

\subsection{RESUMO}

O mogno (Swietenia macrophylla King) é uma espécie arbórea muito utilizada na arborização urbana, por ser uma planta rústica e bem adaptada a diversas regiões do Brasil. Ao analisar folhas de mogno em árvores e mudas produzidas em casa de vegetação em Brasília, Distrito Federal, foram observados sintomas de doença fúngica. Com o objetivo de identificar os fungos causadores de manchas em folhas de mogno e testar sua patogenicidade em mudas, amostras de ramos e folhas de mogno foram coletadas em Brasília, Distrito Federal. Os fungos foram isolados em meio BDA para crescimento e esporulação, visualizados em microscopia óptica e identificados com chaves específicas. Quanto à avaliação da patogenicidade em mudas, foram utilizadas 80 mudas de mogno, onde 40 foram inoculadas com o fungo e 40 serviram como testemunha, sem inoculação. Como resultado, os fungos encontrados foram identificados como Phomopsis sp. (encontrado tanto em mudas quanto em árvores) e Phyllosticta swieteniae Garcia (encontrado apenas em mudas). A partir do teste de patogenicidade, foi possível constatar que ambos os fungos causam doenças em plantas de mogno.

Palavras-chave: patologia florestal, fungos fitopatogênicos, manchas foliares. 


\section{NEW REPORTS OF FOLIAR FUNGI ON MAHOGANY (Swietenia macrophylla King) \\ IN BRAZIL}

\subsection{ABSTRACT}

Mahogany (Swietenia macrophylla King) is a tree species widely used in urban forestry, being a rustic plant, well adapted to different regions of Brazil. By analyzing mahogany leaves in trees located in Brasilia, Distrito Federal, it was observed symptoms of fungal disease. In order to report, identify the fungus stains mahogany leaves and test their pathogenicity on seedlings, samples of branches and mahogany leaves were collected in Brasilia, Distrito Federal. The fungi were isolated in PDA medium for growth and sporulation, viewed in optical microscopy and identified with specific keys. To the avaliation of the pathogenicity in seedlings, 80 mahogany seedlings were used, 40 were inoculated with the fungus and 40 served as a control without inoculation. As a result, two fungi were found and identified as Phomopsis sp. (found in seedlings and trees) and Phyllosticta swieteniae Garcia (found only in seedlings). From the pathogenicity test, both fungi can cause disease in mahogany seedlings.

Keywords: forest pathology, fungi, leaf disease. 


\subsection{INTRODUÇÃO}

O mogno (Swietenia macrophylla King) é uma espécie arbórea muito utilizada na ornamentação urbana, por ser uma planta rústica e bem adaptada a diversas regiões do Brasil. Estudos sobre doenças que acometem a cultura são incipientes e doenças foliares praticamente não tem sido observadas no Brasil.

A principal doença relatada em mogno é a "queima-de-Cylindrocladium", causada pelo fungo Cylindrocladium sp., detectada em folhas de mogno em plantio florestal para recuperação de áreas degradadas na Amazônia (Gasparotto et al., 2014). As folhas infectadas apresentam queima das bordas, que progridem em direção à nervura central. Sclerotium coffeicola Bull., agente causal da mancha-zonada, já foi relatado em mogno nos estados do Pará (Bastos, 1998) e do Amazonas (Assis et al., 2007). Além dessas doenças, já foram relatadas várias espécies do gênero Meliola (Assis et al., 2010), Cylindrocladium floridanum Sobers \& Seym (Mendes et al., 1998), Colletotrichum gloeosporoides (Penz.) Sacc. (Trindade et al., 2004), Erythricium salmonicolor (Berk. et. Br.) Burds (Hadi et al., 1993) e Gloeosporium sp., que causa manchas foliares (Suharti e Irianto, 1992).

Este trabalho teve como objetivo identificar e avaliar a patogenicidade de fungos encontrados em folhas de mogno.

\subsection{MATERIAL E MÉTODOS}

\subsubsection{Detecção de fungos em folhas de mogno}

Manchas foliares foram observadas em árvores de mogno utilizadas na arborização de Brasília e também na condução de mudas da espécie em casa de vegetação na Embrapa Recursos Genéticos e Biotecnologia. As amostras foram analisadas preliminarmente com o auxílio de um microscópio estereoscópio. Sinais do fungo foram retirados com uma agulha esterilizada, colocados em lâminas de vidro com azul de algodão e visualizado em 
microscópio ótico. Para o isolamento do patógeno, regiões das folhas contendo sintomas e sinais foram esterilizadas e colocadas em meio BDA para crescimento e esporulação. Uma cultura pura foi feita a partir da diluição da massa conidial em água destilada e uma colônia do fungo crescido foi transferida para outra placa com meio BDA para crescimento e esporulação.

\subsubsection{Teste de patogenicidade}

Visando a confirmação de que os fungos encontrados nas folhas causavam a lesão, foi realizado o Postulado de Koch. Para tanto foram utilizadas 80 mudas de mogno com dois meses de idade, onde 40 foram inoculadas com o fungo e 40 serviram como testemunha, sem inoculação. Suspensões de conídios $\left(10^{8}\right.$ conídios $\left./ \mathrm{mL}\right)$ obtidas de cultura pura do fungo serviram como fonte de inóculo. A suspensão foi misturada com água destilada, depois pulverizada nas folhas de mogno e o material foi mantido em câmara úmida por 72 horas. A avaliação começou três dias após a inoculação e perdurou por 30 dias, até o completo desenvolvimento da doença e, então, o patógeno foi reisolado das folhas com sintomas.

\subsubsection{Identificação morfológica dos fungos}

Os fungos encontrados nas duas metodologias foram isolados em meio BDA e descritos detalhadamente quanto ao seu crescimento por meio da análise visual do micélio, coloração e forma de crescimento. As estruturas fúngicas foram observadas em microscópio estereoscópio (lupa) e de luz, por meio da confecção de lâminas com corantes a base de lactoglicerol / azul de algodão (Cotton-Blue) ou glicerol KOH / floxina básica, as quais foram seladas com duas camadas de esmalte de unha comercial. As descrições morfológicas foram baseadas em atributos a cerca do conidióforo, célula conidiogênica e conídio, para os fungos 
anamórficos. Para a identificação de cada gênero ou espécie, foram utilizadas chaves específicas de acordo com as suas características anamórficas.

\subsection{RESULTADOS E DISCUSSÃO}

\subsubsection{Fungos foliares encontrados em S. macrophylla}

Dois fungos foliares, ainda não relatados para o mogno no Brasil, foram encontrados, Phomopsis sp e Phyllosticta swieteniae Garcia.

\subsubsection{Phomopsis sp.}

Um dos fungos encontrados foi identificado como Phomopsis, apresentando conidiomas enegrecidos e conídios do tipo alfa e beta, característicos do gênero (Sutton, 1980; Hanlin \& Menezes, 1996) (Figura 1-C). A cultura do fungo em BDA após 10 dias de incubação apresentava coloração branca com conidiomas enegrecidos, apresentando formação abundante de massas conidiais (Figura 1-B).

Os sintomas observados foram manchas foliares circundadas por faixa estromática anfígena marrom-escura a negra com pontos negros (conidiomas) distribuídos em área interna marrom-clara (Figura 1-A). Agente causal: micélio hialino, septado, imerso no tecido da hospedeira; pseudostroma anfígeno, com micélio interno hialino, incorporando células degradadas marrons, circundado por tecido melanizado enegrecido; conidiomas clipeados, anfígenos, imersos, mesófilos, irrompentes, estromáticos, marrom-escuros a negros; células conidiogênicas enteroblásticas fialídicas, cilíndricas, hialinas; conídios $\alpha \quad 6,5-9,75$ x 2,5 $\mu \mathrm{m}$ hialinos, gutulados, oblongo-elipsóides, asseptados; conídios $\beta 14-28,5$ x 1,0 $\mu \mathrm{m}$ hialinos, filiformes, apicalmente uncinados ou retos (Figura 1-C). 


\subsubsection{Phyllosticta swieteniae}

O segundo fungo causador de manchas em folhas foi identificado como Phyllosticta swieteniae, através da análise morfológica e morfométrica dos conídios. A cultura do fungo em BDA após 10 dias de incubação era negra com conidiomas acinzentados, com crescimento irregular.

Os sintomas observados foram manchas necróticas, principalmente nas folhas mais velhas, com área central descolorida, geralmente marrom, margens negras, picnídios numerosos (Figura 1-D); Agente causal: conidiomas picnidiais, gregários, uniloculares, subglobosos a globosos, ostiolados, não-rostrados, parede com textura angularis com 2-3 camadas (Figura 1-E); Células conidiogênicas hialinas, ampuliformes a cilíndricas; Conídios 6,6 (8,5) 11,5 mm x $5(6) 7 \mathrm{~mm}$ hialinos, globosos, subovóides (Figura 1-F).
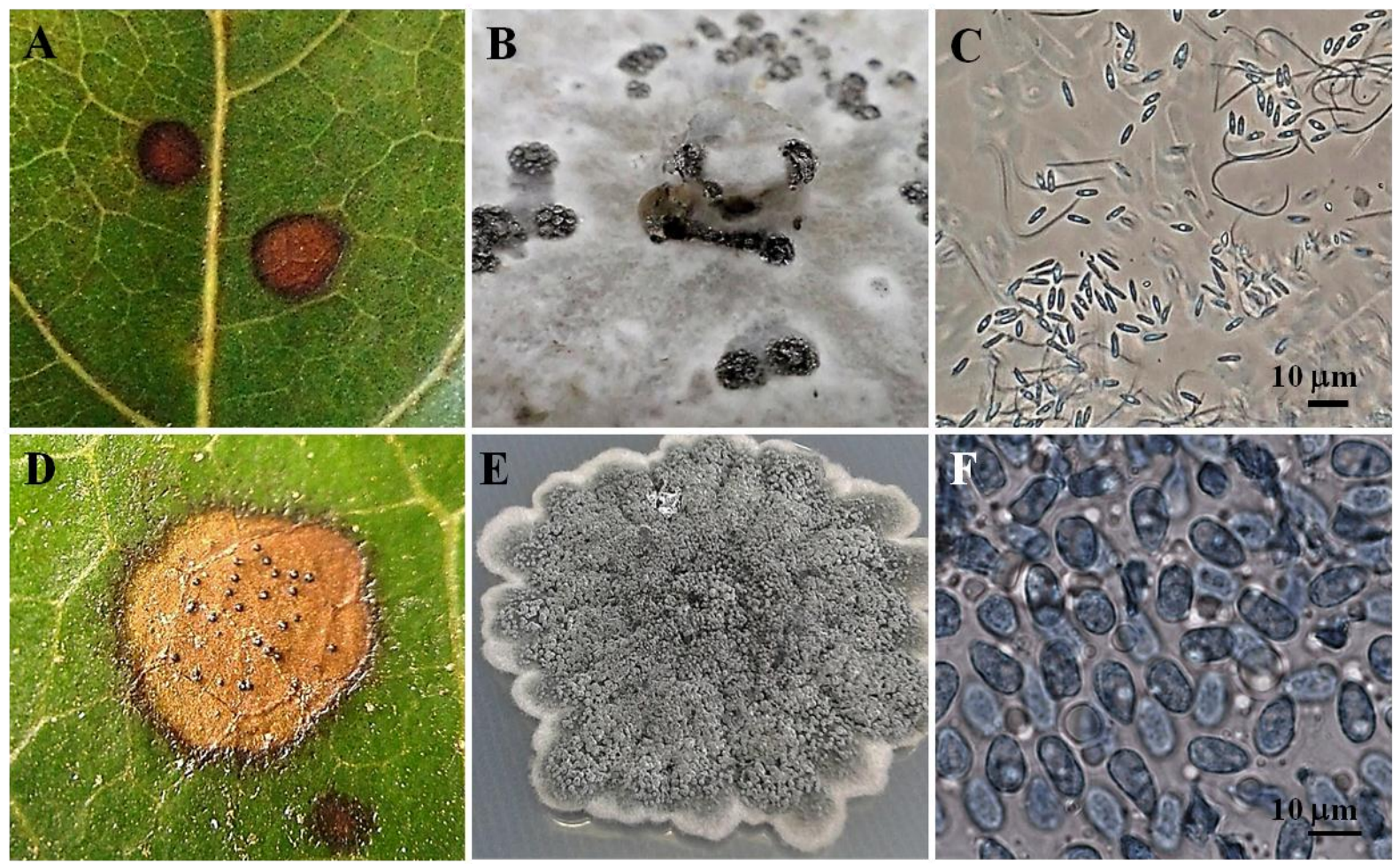

Figura 1 (A - F). Fungos foliares associados ao mogno. A - Manchas foliares causadas por

Phomopsis sp. em mogno. B - Cultura do fungo em meio BDA. C - Conídios alfa e beta 
vistos em microscopia de luz. D - Mancha foliar causada por Phyllosticta swieteniae em mogno. E - Cultura do fungo em meio BDA. F - Conídios vistos em microscopia de luz.

O teste de patogenicidade mostrou que os fungos isolados das folhas são patogênicos, pois $70 \%$ (Phomopsis sp.) e 65\% (P. swieteniae) das mudas inoculadas reapresentaram os sintomas e o patógeno reisolado apresentou as mesmas características do fungo isolado da lesão coletada, fechando o postulado.

O gênero Phomopsis conta com mais de 1000 espécies descritas, 29 variedades e 16 formae speciales (Kirk et al., 2001). A taxonomia do fungo tem sido baseada na associação aos hospedeiros (Uecker, 1988). É reconhecido atualmente que o hospedeiro constitui uma característica taxonômica de menor importância, pois a mesma espécie pode ocorrer em vários hospedeiros e num mesmo hospedeiro podem ocorrer mais de uma espécie fúngica (Rehner \& Uecker, 1994). No entanto, este gênero ainda não foi taxonomicamente revisto. Estudos moleculares devem ser realizados para definir se o fungo encontrado associado ao mogno é uma provável espécie nova dentro do gênero ou não.

Espécies de Phomopsis são comumente encontradas como patógenos e endófitos de plantas (Maki, 2006). Como patógeno, é responsável por diversas doenças em muitas espécies vegetais, como por exemplo, causam queimaduras nas folhas de aroeira e jatobá (Anjos et al., 2001).

A espécie $P$. swieteniae foi descrita originalmente associada à Swietenia mahagoni (L.) Jacq. em Porto Rico. Segundo o autor, a infecção é favorecida pelo excesso de umidade, com a germinação dos conídios na superfície da folha, desenvolvendo manchas necróticas que se estendem gradualmente para o pecíolo e as folhas finalmente caem. Apesar das medidas morfométricas da espécie encontrada serem um pouco diferentes com as da descrição original (Garcia, 1939), foi admitido que os fungos sejam os mesmos. Entretanto, este é o primeiro 
relato de $P$. swieteniae associado à $S$. macrophylla e também o primeiro registro de ocorrência do fungo no Brasil.

As duas espécies fúngicas foram encontradas nas mudas, porém apenas Phomopsis sp. foi encontrado nas árvores de Brasília. Aparentemente os dois fungos não causaram grandes danos para as plantas, apesar de serem comprovadamente patogênicos. Porém, medidas de controle preventivas devem ser tomadas com o propósito de evitar que esses fungos possam vir a se tornar um problema.

Análises moleculares estão sendo realizadas para ambos os fungos, com o propósito de definir precisamente suas respectivas posições taxonômicas.

\subsection{CONCLUSÕES}

- Os fungos Phomopsis sp. e Phyllosticta swieteniae foram encontrados em folhas de mudas de mogno;

- Phomopsis sp. foi encontrado também nas árvores de Brasília;

- Quando inoculados nas mudas, ambos os fungos causaram doença e são relatados pela primeira vez em mogno no Brasil.

\subsection{REFERÊNCIAS BIBLIOGRÁFICAS}

ANJOS, J. R. N. DOS; CHARCHAR, M. J. A.; GUIMARÃES, D.P. 2001. Ocorrência de queima das folhas causada por Phomopsis sp. em aroeira no Distrito Federal. Fitopatologia Brasileira, v. 26, n. 6, p. 649-650.

ASSIS, L. A. G.; COELHO NETTO, R. A.; BARBOSA, A. P. 2007. Ocorrência de mancha foliar em mogno causada por Sclerotium coffeicola no estado do Amazonas. Summa Phytopathologica, v. 33, n. 1, p. 99. 
ASSIS, L. A. G.; COELHO NETTO, R. A.; BARBOSA, A. P.; BEZERRA, J. L.; GASPAROTTO, L.; SOUSA, F. M. G. 2010. Parasitas fúngicos em espécies florestais nativas da Amazônia Central. Agrotrópica, v. 22, n. 3, p. 137-144.

BASTOS, C. N. 1998. Mancha foliar em mogno (Swietenia macrophylla King) causada por Sclerorium coffeicolum Stahel. Agrotrópica, v. 10, n. 1, p. 41-42.

GARCIA, L. A. 1939. A mahogany seedling blight in Puerto Rico. Caribbean Forester, v. 1, p. 23-24.

GASPAROTTO, L; BENTES J. L. S; PEREIRA, J. C. R. 2014. Doenças de espécies florestais arbóreas nativas e exóticas na Amazônia. Embrapa, Brasília, DF. 209 p.

HADI, S.; NUHAMARA, S. T.; SANTOSO, E.; NAIR, K. S. S.; SHARMA, J. K.; VARMA, R. V. (Ed). 1993. Impacto of diseases and insect pests in tropical forests. In: IUFRO SYMPOSIUM, 1993, Peechi, India. Proceedings... Peechi: IUFRO, p. 105-110.

HANLIN, R.; MENEZES, M. 1996. Gêneros Ilustrados de Ascomicetos. Recife. Imprensa UFPE. 247p.

KIRK, P. M.; CANNON, P. F.; DAVID, J. C.; STALPERS, J. A. 2001. Ainsworth and Bisby's dictionary of the fungi. 9th ed. Surrey. $655 \mathrm{p}$. 
MAKI, C. S. 2006. Diversidade e potencial biotecnológico de fungos endofíticos de cacau

(Theobroma cacao L.). Tese de doutorado - Escola Superior de Agricultura "Luiz de Queiroz”. Universidade de Sao Paulo, Piracicaba.

MENDES, M. A. S.; SILVA, V. L.; DIANESE, J. C.; FERREIRA, M. A. S. V.; SANTOS, C. E. N.; GOMES NETO, E.; URBEN, A. F.; CASTRO, C. 1998. Fungos em plantas no Brasil. Brasília, DF: Embrapa-SPI: Embrapa-Cenargen, 569 p.

REHNER, S. A.; UECKER, F. A. 1994. Nuclear ribossomal transcribed spacer phylogeny and host diversity in the coelomycete Phomopsis. Canadian Journal of Botany, v. 72, n. 11, p. 1666-1674.

SUHARTI, M.; IRIANTO, R. S. B. 1992. Virulence trial for four species of fungus that cause leaf spot disease on Eucalyptus urophylla and Swietenia macrophylla. Buletin Penelitian Hutan, Bogor, n. 553, p. 33-48.

SUTTON, B. C. 1980. Coelomycetes: fungi imperfecti with pycnidia, acervuli and stromata. Kew: Surrey, England, C.M.I., p. 696.

UECKER, F. A. 1988. A world list of Phomopsis names with notes on nomenclature, morphology, and biology. Mycologia Memoir, v. 13, p. 1-323. 


\section{CONSIDERAÇÕES FINAIS}

Os objetivos propostos foram alcançados. Estudos sobre a sua principal praga, Hypsipyla grandella, foram realizados no intuito de aumentar o conhecimento acerca do inseto e também de oferecer subsídios para o seu controle de forma menos danosa ao meio ambiente, com o uso de agentes de biocontrole. Além disso, foram descritos organismos inéditos associados ao mogno.

A análise da predação de frutos de mogno pela $H$. grandella mostrou que o inseto reduz a oferta de sementes da espécie e que muitos frutos caem devido ao seu ataque. Além disso, o inseto foi criado com uma dieta natural de sementes de mogno, o que mostra que este é um alimento apropriado para o mesmo. Durante a análise dos frutos, foi encontrada uma lagarta morta por causas fúngicas. Os experimentos mostraram que este fungo foi, possivelmente, o responsável pela morte da lagarta e o isolado foi identificado e testado em outras lagartas, comprovando a sua patogenicidade. Além do fungo, várias estirpes de Bacillus thuringiensis foram testadas e comprovadas como tóxicas à $H$. grandella. Por fim, esse trabalho também mostrou que algumas estirpes de $B$. thuringiensis possuem algum efeito sistêmico em mudas de mogno e que estas apresentam potencial para um novo método de controle da $H$. grandella.

Foram encontrados dois ácaros associados ao mogno, sendo que um deles é uma espécie nova para a ciência e será publicada em breve. A segunda, apesar de ser uma espécie conhecida, é pela primeira vez observada em folhas de mogno no mundo. Ambas as espécies apresentam potencial de causar danos foliares e a provável espécie nova de eriofídeo também causa deformações nas gemas axilares, levando ao superbrotamento, o que poderá inviabilizar a venda de algumas mudas.

Dois novos fungos foliares foram encontrados, ambos inéditos para o Brasil, e um fungo patogênico foi isolado das sementes de mogno, comprovando que estudos acerca da 
fitossanidade da espécie ainda são escassos e incipientes. Investigações mais profundas com relação à fitopatologia da espécie devem ser realizadas.

Por fim, por ser uma espécie ameaçada de extinção, estudos sobre a silvicultura, produção de sementes e a sanidade das plantas de mogno, além do controle dos seus respectivos agentes danosos, são necessários e devem ser realizados para preservar e conservar essa espécie tão importante para o mundo. 